Review

\title{
The Toxicity of Secondary Lithium-Sulfur Batteries Components
}

\section{Krzysztof Siczek (D)}

Department of Vehicles and Fundamentals of Machine Design, Lodz University of Technology, 90-537 Lodz, Poland; ks670907@p.lodz.pl

Received: 21 June 2020; Accepted: 3 September 2020; Published: 6 September 2020

\begin{abstract}
Currently, apart from the widely known lithium-ion batteries, there are competitive solutions in the form of, for example, Li-S batteries. While the results of studies on the toxicity of Li-ion battery components are published, such studies on the components of Li-S cells are just beginning. The purpose of the current review was to identify materials used in the production of Li-S batteries and their toxicity, especially for humans. The review showed many kinds of materials with different levels of toxicity utilized for manufacturing of these cells. Some materials are of low toxicity, while some others are of the high one. A lot of materials have assigned different hazard statements. For some of the materials, no hazard statements were assigned, although such materials are toxic. No data related to the toxicity of some materials were found in the literature. This points out the need to further studies on their toxicity and legal actions to assign appropriate hazard statements.
\end{abstract}

Keywords: lithium-sulfur cell; energy density; material toxicity; hazard statements

\section{Introduction}

In order to improve energy rationalization and air quality improvement, nowadays the major vehicles makers develop new solutions equipped with electric power trains.

According to De Lorenzo et al. [1], there exists three different solutions for them:

(a) Batteries electric vehicles (BEV), with the devices storing the electric energy from the electric network during the charging process and feeding an electric motor of the vehicles during the discharging process;

(b) Fuel cells electric vehicles (FCEV), with the polymer electrolyte fuel cells (PEFCs) producing all the electrical energy needed to the electric motor of the vehicles. The PEFCs are fed by hydrogen accumulated in a suitable system on the vehicles board or which is steadily generated from hydrocarbons or alcohols by a proper generation system;

(c) Hybrid electric vehicles (HEVs), with batteries and/or PEFCs integrated into a hybrid system feeding the electric motor of the vehicles with or without ICE.

De Lorenzo et al. [1] summarized the advantages and disadvantages of BEV and FCEV. In a HEV, the PEFCs increase its autonomy while batteries allow the reduction of its manufacturing costs. City buses are better predestined to the PEFC system, comprising the PEFC stack with its auxiliary systems and the hydrogen and electrical energy storage systems.

De Luca et al. [2] proposed also a fuel cell hybrid electric vehicle (FCHEV) predestined for an application to two-wheeled vehicles.

Fragiacomo P. et al. [3] proposed the other hybrid energy system using an anion exchange membrane fuel cell (AEMFC).

The mentioned electrical and hybrid systems utilized Li-ion batteries (LIBs) due to their availability and a good recognition of their technology. 
As the standard Li-ion batteries (LIBs) are already facing the energy density limit, many of their alternatives are investigated [4]. The studies on the toxicity and hazards of materials used during manufacturing of Li-ion cells were presented, for example, in [5,6]. The lithium-sulfur batteries were intensively studied due to, i.e., nontoxicity of sulfur used as the component of the cathode material [7-9]. The restricted use of Li-S cells results from the low load of sulfur and poor cycle life caused by the weak conductivities of $S$ and its discharge products $\mathrm{Li}_{2} \mathrm{~S}$, the shuttling of the soluble $\mathrm{Li}_{2} \mathrm{~S}_{\mathrm{n}}(4 \leq \mathrm{n} \leq 8)$ between the anode and the cathode, and the large volumetric change between $S$ and $\mathrm{Li}_{2} \mathrm{~S}$ [7-9].

In [10], a comprehensive life cycle assessment (LCA) model was elaborated to study the life cycle environmental effects of Li-S cells. In this article, no emphasis was placed on the toxicity of materials used to produce components of Li-S cells.

A typical Li-S cell shown in Figure 1 possesses a composite C/S, a cathode, and a metallic Li anode with a liquid organic electrolyte between them [11]. The scheme of Li-S battery configuration with an organic liquid electrolyte is presented in Figure 1. During discharging, the $S$ is reduced to $\mathrm{Li}_{2} \mathrm{~S}$ on the electrode with the simultaneous formation of intermediate polysulfides.

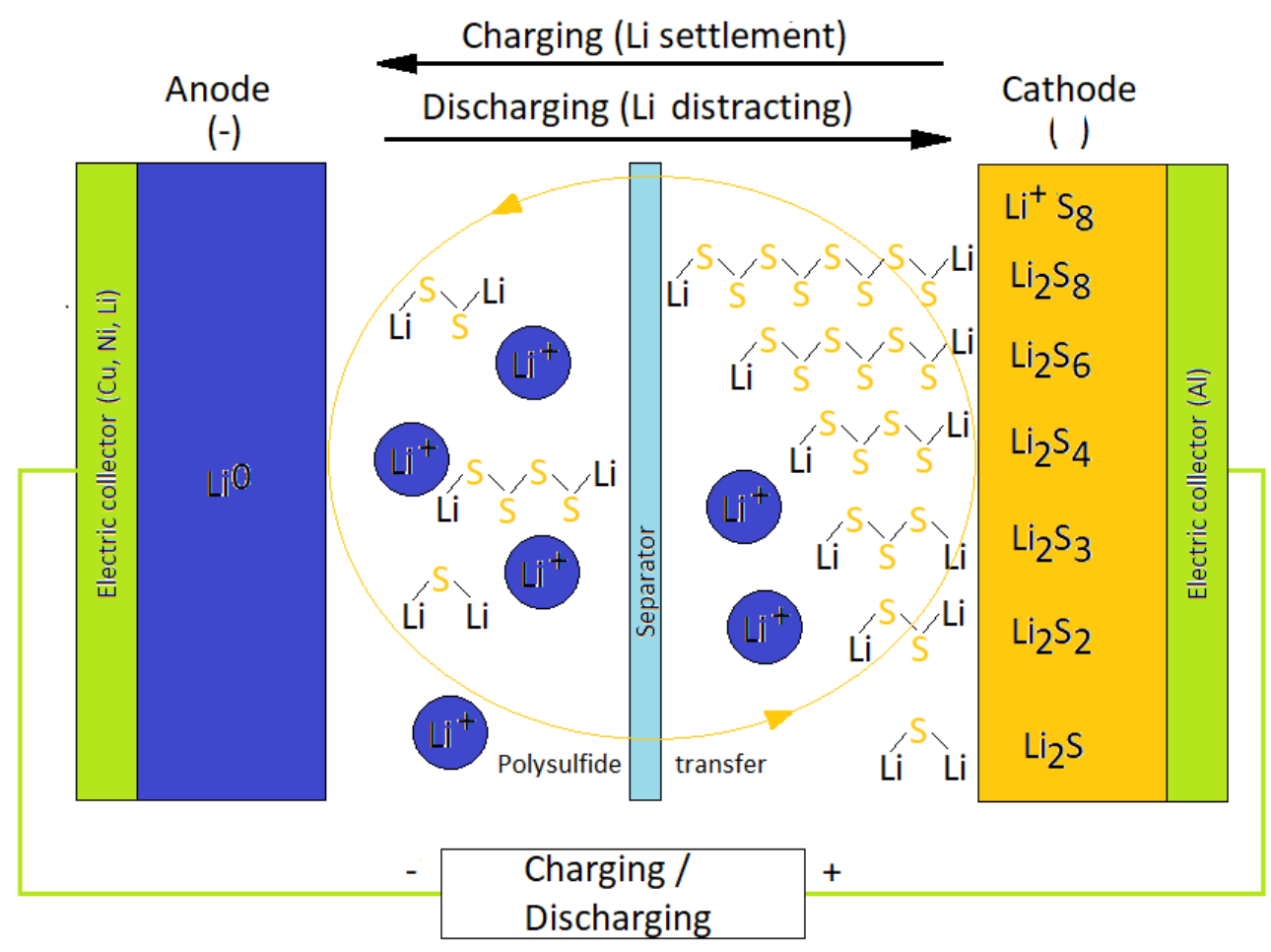

Figure 1. Li-S battery configuration employing organic liquid electrolyte [11].

The first Li-S cell concept was described in [12]. The first such cell was developed with elemental $\mathrm{S}$ as a cathode, $\mathrm{Li}$ anode, and Li salts dissolved in organic solvents as electrolyte [13].

Interestingly, according to [14], sulfur is a flammable solid and can cause skin irritation.

As reported in [15], sulfur is able to be harmful after swallowing or inhalation. It can induce skin irritation.

The sample information related to the hazards of sulfur are presented in Table 1.

Many new $S$ cathodes have been developed to increase electronic conductivity and limit dissolution [7,16-24]. The conductive porous matrix, such as nanostructured carbon, conductive polymers, as a host for active sulfur forms, and physical or chemical impeding dissolution and diffusion of polysulfides (PS) to mitigate the loss of active material and limit the shuttle effect have remained the objects of researchers' great interest. Intensive studies have been also carried out on Li-S electrolytes. 
Table 1. Hazard statements related to sulfur.

\begin{tabular}{ccc}
\hline Material & Class of EC 1272/2008 & References \\
\hline \multirow{2}{*}{ Sulfur } & H315, H228 & {$[14]$} \\
& H303, H313, H315, H333 & {$[15]$}
\end{tabular}

H228-Flammable solid; H303-May be harmful if swallowed; H313-May be harmful in contact with skin; H315-Causes skin irritation; H333-May be harmful if inhaled.

According to [25], lithium-sulfur batteries (LSBs) are non-toxic and environmentally friendly.

Petr Novák [26] stated that no toxic chemicals are used in the manufacture of Li-S cells.

Benveniste et al. [27] pointed that the Li-S cells showed weaker environmental impacts than lithium nickel manganese cobalt oxide (NMC) Li-ion. Li-S cells had a lower GWP (the category explained the effect of mankind in a globalized world) by $20 \%$ than that of NMC Li-ion cells, but their main shares manifested in limitation on resource depletion and human toxicity.

The goal of this review is to check actual information according to materials and their toxicity of components used in new energy-storage systems such as the Li-S cells and batteries.

\section{Results and Discussion}

\subsection{Materials Used to Limit the Shuttle-Effect in Li-S Cells}

Liu et al. [28] reported that the PS shuttle effect always occurs in Li-S cells with liquid electrolytes. Various endeavors have been made to decrease the unwanted PSs shuttle effect. Such attempts included, inter alia, the use of S/(CNT@MPC) composite cathode or graphene/CNT@porous carbon cathode, encapsulation sulfur into a thin wall hollow spherical structured polypyrrole (T-HSSP) to produce S@PPy composites, introduction of an electrolyte-permeable microporous carbon paper between the sulfur cathode and separator, swap of liquid electrolytes by solid ones.

Yu et al. [29] obtained a $\mathrm{TiO}_{2}-\mathrm{N}$ doped graphene/sulfur $\left(\mathrm{TiO}_{2}-\mathrm{NG} / \mathrm{S}\right)$ hybrid structure. The $\mathrm{N}$ doped graphene was applied as a conductive matrix and the $\mathrm{TiO}_{2}$ cover on the NG/S electrodes surface greatly limited the Li polysulphides shuttle.

No data directly related to the toxicity of a $\mathrm{TiO}_{2}-\mathrm{N}$ doped graphene/sulfur $\left(\mathrm{TiO}_{2}-\mathrm{NG} / \mathrm{S}\right)$ were found in the literature.

However, Wang and Jiang (2015) [30] investigated the toxic impacts of graphene oxide (GO) and $\mathrm{N}$-doped graphene quantum dots (N-GQDs) on red blood cells (RBCs). The toxicity mechanism was uncovered by observation of the structural changes of RBCs lipid on model membranes. The adsorption of GO destructed the integrality of the membrane by extracting the lipid bilayer, causing hemolysis and aberrant forms. Contrary, N-GQDs disturbed the structure and conformation of lipid, causing merely aberrant cells.

According to [31], graphene nanoplatelets are able to form a combustible dust-air mixture. They may induce eye irritation and skin irritation and respiratory tract irritation.

As reported in [32], conductive graphene sheets can be irritant to the skin and mucous membranes. It also can cause eye irritation.

According to $[33,34]$, the wide utilization of $\mathrm{TiO}_{2}$ is related to the ratio of cost to photocatalytic (PC) activity, weak toxicity, and its band gap of $3.2 \mathrm{eV}$ (when in the anatase polymorph) that is activated during irradiation of the semiconductor by ultraviolet (UV) light.

Moreover, Grande and Tucci (2016) [35] reported that titanium dioxide $\left(\mathrm{TiO}_{2}\right)$ is of weak toxicity and insignificant biological effects. The human endangering may occur via ingestion, dermal penetration, or inhalation during both the manufacturing process and utilization. The potential toxicity of $\mathrm{TiO}_{2}-\mathrm{NPs}$ manifests in the reactive oxygen species (ROS) generation, causing oxidative stress, inflammation, genotoxicity, metabolic change, and potentially carcinogenesis. The extent and type of cell damage is strongly affected by size, crystal structure, and photo-activation of $\mathrm{TiO}_{2}-\mathrm{NPs}$.

Some hazard statements assigned to $\mathrm{TiO}_{2}$ were presented in Table 2 . 
As reported in [36], $\mathrm{TiO}_{2}$ may induce irritation of eyes and skin. It may induce irritation when inhaled and be of low toxicity when ingested. It is suspected of inducing cancer. It is non-flammable, except as powder.

Zhou et al. [37] utilized a $\mathrm{TiO}_{2}$ nanowire-embedded graphene $\left(\mathrm{TiO}_{2} \mathrm{NW} / \mathrm{G}\right)$ hybrid membrane. In such membrane, the graphene was applied as the current collector, while the $\mathrm{TiO}_{2} \mathrm{NWs}$ impeded a PSs shuttling and as the catalyst to increase the PS reduction and oxidation.

$\mathrm{Li}$ et al. [38] developed a carbonized bacterial cellulose/titania $\left(\mathrm{CBC} / \mathrm{TiO}_{2}\right)$ modified separator.

No data related to the toxicity of $\mathrm{TiO}_{2}$ nanowire-embedded graphene $\left(\mathrm{TiO}_{2} \mathrm{NW} / \mathrm{G}\right)$ and a carbonized bacterial cellulose/titania $\left(\mathrm{CBC} / \mathrm{TiO}_{2}\right)$ were found in literature.

However, according to [39], the acute, sub-acute, and subchronic oral toxicity assays proved that the intake of bacterial cellulose (BC) showed no adverse impacts in rats and mice. BC was also non-irritating in the rabbit models. The BC demonstrated its biocompatibility and triggered no harsh inflammatory reaction.

Guo et al. [40] produced a free-standing $\mathrm{MnO}_{2}$ nanowire and graphene nanoscroll (GNSM) interlayer, with the weight ratio of graphene nanoscroll to $\mathrm{MnO}_{2}$ nanowires equal to 4:1.

Manganese oxides $\left(\mathrm{MnO}_{2}\right.$ and $\left.\mathrm{Mn}_{3} \mathrm{O}_{4}\right)$ as pseudocapacitive electrode materials showed environmental friendliness [41-43].

Some hazard statements assigned to $\mathrm{MnO}_{2}$ are presented in Table 2.

Ji et al. [44] reported that $\mathrm{MnO}_{\mathrm{x}}$ (i.e., $\mathrm{MnO}, \mathrm{MnO}_{2}, \mathrm{Mn}_{2} \mathrm{O}_{3}$, and $\mathrm{Mn}_{3} \mathrm{O}_{4}$ ) are non-toxic.

According to [45], $\mathrm{MnO}_{2}$ is harmful after swallowing or inhalation. It is not combustible but enhances the combustion of other substances.

As reported in [46], $\mathrm{Mn}_{3} \mathrm{O}_{4}$ is non-flammable. It may induce irritation of eyes and skin. It is able to cause irritation when ingested or inhaled. Chronic endangering to manganese may induce impairment to the central nervous system.

Liu et al. [47] elaborated a $\mathrm{V}_{2} \mathrm{O}_{5}$-decorated carbon nanofiber interlayer for limiting the self-discharge and shuttle effect.

As reported in [48], the health hazards of carbon fibre handling are due to mechanical irritation and abrasion such as that of glass fibres. As carbon fibres are breakable during stretching, they change into a fine dust during mechanical machining and release them into the milieu. These micro fibres can stick into the human skin or mucous membranes inducing irritation.

Some hazard statements assigned to $\mathrm{V}_{2} \mathrm{O}_{5}$ are presented in Table 2.

Whittingham [49] reported that the vanadium pentoxide $\left(\mathrm{V}_{2} \mathrm{O}_{5}\right)$ can be used as a cathode material of low toxicity.

According to [50], $\mathrm{V}_{2} \mathrm{O}_{5}$ is harmful after swallowing or inhalation. It may induce respiratory irritation. It is suspected of inducing genetic defects and of damaging the unborn child. It also induces damage to organs through prolonged or repeated endangering. It is toxic to aquatic life.

Table 2. Hazard statements related to $\mathrm{TiO}_{2}, \mathrm{MnO}_{2}$, and $\mathrm{V}_{2} \mathrm{O}_{5}$.

\begin{tabular}{ccc}
\hline Material & Class of EC 1272/2008 & References \\
\hline $\mathrm{TiO}_{2}$ & $\mathrm{H} 351$ & {$[36]$} \\
$\mathrm{MnO}_{2}$ & $\mathrm{H} 302, \mathrm{H} 332$ & {$[45]$} \\
$\mathrm{V}_{2} \mathrm{O}_{5}$ & $\mathrm{H} 302, \mathrm{H} 332, \mathrm{H} 335, \mathrm{H} 341, \mathrm{H} 361 \mathrm{~d}$, & {$[50]$}
\end{tabular}

H302--Harmful if swallowed; H332-Harmful if inhaled; H335-May cause respiratory irritation; H341—Suspected of causing genetic defects; H351-Suspected of causing cancer; H361d-Suspected of damaging the unborn child; H372-Causes damage to organs through prolonged or repeated exposure; H411-Toxic to aquatic life with long-lasting effects. 


\subsection{Cell Configuration}

The Li-S system, due to its high volumetric and gravimetric energy densities is suitable for both secondary and primary battery appliances [51].

Liu et al. [52] found that the development of hierarchical gradient cathodes, solid state electrolytes, functional separators, and anodic protection strongly affects the intensification of Li-S cells.

In the simplest arrangement [13], the Li-S cell contained the cathode that consists of solid sulfur and soot, while the Li anode and the electrolyte contained a Li salt soluble in organic solvents. A proper binder preserves the integrality of the structure $[13,53]$ electrodes. The low discharge efficiency can result from the formation of soluble PSs diffusing between electrodes of the cell, where self-discharge takes place [54]. The insulating material of the cathode and the $\mathrm{Li}_{2} \mathrm{~S}$ or $\mathrm{Li}_{2} \mathrm{~S}_{2}$ final product can cause the low cyclability performance [11]. To utilize a liquid cathode [55], soluble $S$ rather than the solid one is used to increase the discharge efficacy. A PS solution $\left(\mathrm{Li}_{2} \mathrm{Sn}\right)$ in tetrahydrofuran (THF) comprising $\mathrm{LiAsF}_{6}$ results from the reaction of a stoichiometric quantity of $\mathrm{S}$ with $\mathrm{Li}_{2} \mathrm{~S}$.

Here, it is necessary to mention that according to [56] $\mathrm{LiAsF}_{6}$ is toxic after swallowing or inhalation and is very toxic to aquatic life.

Some hazard statements assigned to $\mathrm{LiAsF}_{6}$ are presented in Table 3.

The liquid electrode holds a sure electrical contact with the current collector of the Li-S cell. Inside the cell, the reduction kinetics of the low order PSs is slow and the $\mathrm{Li}_{2} \mathrm{~S}$ passivation layer is developed on the cathode. The soluble $\mathrm{Li}_{2} \mathrm{~S}$ additives and/or complexing agents for $\mathrm{S}^{2-}{ }_{\mathrm{n}}$ increase the discharge rate and capacity of the cell. The former greatly limit the development of a passivation layer at the cathode, and the latter provides the high rate of reduction of low-order PSs. The concentrated PS solution is consistent with metallic $\mathrm{Li}$ [55]. $\mathrm{Li}_{2} \mathrm{~S}$ formation on the anode passivates metallic $\mathrm{Li}$ and provides a high system harmony. The dendritic form of Li does not increase in the Li-S cell of a simple arrangement when the PSs can be transferred between the anode and the cathode. The change of liquid electrolyte by polymer one or gel one increases the cyclability performance of Li-S cell through slowing the PS shuttle effect [57-66]. Polymer electrolyte plays the role of both electrolyte and separator. It also limits PSs in the cathode area and the migration of $S$ to the anode area during the cell operation. However, at room temperature, the polymeric electrolyte, such as poly (ethylene oxide) (PEO) [67] has the low ionic conductivity. Therefore, the Li-S cell with polymer electrolytes needs to operate at a high temperature to reach the satisfactory level of ion conductivity. The ionic conductivity increases with the introduction of ceramic fillers such as $\mathrm{Al}_{2} \mathrm{O}_{3}, \mathrm{ZrO}_{2}$, etc. $[66,68,69]$. However, the loss of capacity is so far an unresolved issue. The use of a polymeric or gel electrolyte cannot eliminate the formation of Li dendrites. Safety problems associated with the anode can occur in the Li-S cells with polymeric electrolytes. The arrangement with only solid components utilizes the glass ceramic electrolytes [70-74]. Glass ceramics such as $\mathrm{Li}_{2} \mathrm{~S}-\mathrm{SiS}_{2}$ [75] and $\mathrm{Li}_{2} \mathrm{~S}_{-} \mathrm{P}_{2} \mathrm{~S}_{5}$ [76] have strong conductivity at room temperature, and glass ceramic electrolytes have a number of lithium-ion transports equal to one, which is more advantageous than for the cases of polymeric electrolytes [70]. The electrolyte is a cathode component increasing its ionic conductivity [70].

The schematic cell traditional and one of new arrangements for Li-S cells are shown in Figure 2. 


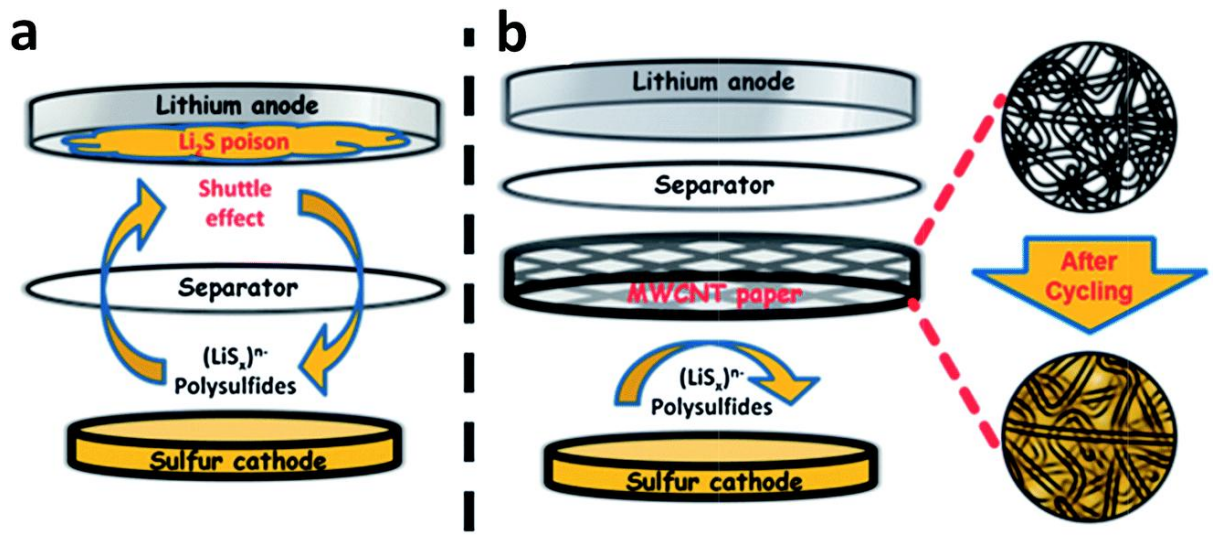

Figure 2. The schematic arrangement of Li-S cell: (a) Traditional arrangement with severe shuttle effect and $\mathrm{Li}_{2} \mathrm{~S}$ poison problems; (b) new arrangement with the multi-walled carbon nanotube (MWCNT) interlayer. Taken from [52].

Some hazard statements assigned to lithium metal are presented in Table 3.

According to [77], there are three possible severity grades of the Li toxicity: Mild, moderate, and severe. Mild symptoms contain nausea, vomiting, lethargy, tremor, and fatigue. Moderate intoxication contains confusion, agitation, delirium, tachycardia, and hypertonia. Severe one contains coma, seizures, hyperthermia, and hypotension.

Table 3. Hazard statements of $\mathrm{LiAsF}_{6}$ and lithium metal.

\begin{tabular}{ccc}
\hline Material & Class of EC 1272/2008 & References \\
\hline & $\mathrm{H} 301, \mathrm{H} 319, \mathrm{H} 320, \mathrm{H} 331, \mathrm{H} 350$, & \\
LiAsF $_{6}$ & $\mathrm{H} 360, \mathrm{H} 361, \mathrm{H} 370, \mathrm{H} 372, \mathrm{H} 400$, & {$[47]$} \\
Lithium Metal & $\mathrm{H} 410$ & {$[78]$} \\
\hline
\end{tabular}

H260-In contact with water releases flammable gases which may ignite spontaneously; H301-Toxic if swallowed; H314-Causes severe skin burns and eye damage; H319-Causes serious eye irritation; H320-Causes eye irritation; H331-Toxic if inhaled; H350 - May cause cancer; H360-May damage fertility or the unborn child; H361 - Suspected of damaging fertility or the unborn child; H370-Causes damage to organs; H400-Very toxic to aquatic life; H410-Very toxic to aquatic life with long-lasting effects.

\subsection{Materials for the Cathode}

According to [28], a cathode is crucial for Li-S batteries.

To obtain good cyclability of Li-S batteries, a lot of materials have been developed for cathodes, including $\mathrm{C} / \mathrm{S}$ and polymer-sulfur composites, organic sulfides, inorganic additives, and many new binders.

Many strategies were used to improve the $S$ load and decrease the dissolution of PS intermediates. They included: Application of S host materials [79-83], protective coating layers [84-88], and interlayer between cathode and separator $[89,90]$, promoting the springing up of the $S$ cathodes with strong specific capacities. Most of the presented Li-S cells had the weak S content and/or weak S loading. The corresponding areal capacities were smaller than these of the LiBs [91-93].

Interestingly, no data related directly to the toxicity of $C / S$ and polymer-sulfur composites, organic sulfides, and inorganic additives applied to cathodes in Li-S cells were found in literature. Moreover, no data related directly to the toxicity of $S$ host materials, protective coating layers, and interlayers between cathodes and separators in the Li-S cells were available. Such a toxicity can be only roughly estimated using data available for individual chemical components of the materials used for the mentioned LI-S parts. However, this can be made without considering the effect of interaction between them on the overall toxicity of the entire chemicals. 
For example, according to [94], elemental C is of very weak toxicity. A health hazard can occur when humans are exposed to carbon black, not elemental C. Chronic inhalation endangering to carbon black may cause temporary or permanent damage of lungs and heart. Pneumoconiosis occurred in employees producing carbon black. Inflammation of the hair follicles, and oral mucosal lesions occurred during skin endangering. Carbon black was not classifiable as carcinogenic to humans. Some simple $\mathrm{C}$ compound can be very toxic, such as carbon monoxide $(\mathrm{CO})$ or cyanide $(\mathrm{CN})$. No negative environmental impact of $C$ has been reported.

\subsection{Binders}

The binders provide the structural integrality of the electrodes, and as a result the capacity and the cyclability of Li-S cells [95].

Frischmann et al. [96] found that binders succor in electrode processing and drying on to Al current collectors, electrolyte wetting during cell arrangement, ion transport, and mechanical integrality upon cycling to accommodate the volume changes that resulted from $\mathrm{LiS}_{8}-\mathrm{Li}_{2} \mathrm{~S}$ interconversion.

Some information related to the toxicity of $\mathrm{Al}$ were found in literature.

According to [97], $\mathrm{Al}$ is non-hazardous and does not create a risk to humans or the milieu. Nevertheless, any machining, or use for deposition produces dust, fume, or particulates containing component elements of this material. Endangering to these components can cause significant health hazards. Fine particulate may be a combustible dust which, when dispersed in air, may explode.

It is necessary to mention that Exley [98] reported that aluminium can be toxic for humans especially under chronic endangering.

Polyethylene oxide (PEO), gelatin, polyvinyl pyrrolidone (PVP), Na-alginate, gum Arabic (GA), etc., can be variants to common polyvinylidene difluoride (PVDF) [99-104].

According to [105], polyethylene oxide may be harmful after inhalation, swallowing, or absorption through the skin. It may induce irritation of respiratory tract, skin, or eye.

As reported in [106], gelatin is generally recognized as a non-hazardous food or food ingredient.

As reported in [107], polyvinylpyrrolidone (PVP) did not irritate or induce sensitization during application to the human skin and did not irritate the eyes of rabbits. It exhibited weak acute toxicity during administration by the intravenous route in humans or by the oral and intravenous routes in various species of animals. In humans, injections caused PVP deposits in the reticulo-endothelial system and structural changes. Repeated oral administration in rabbits, dogs, and rats caused deposits and changes in the liver and lymph nodes. No carcinogenicity was found in rats handled by the oral route, but an association occurred between tumor growth and PVP injection in rodents. No genotoxicity occurred during the Ames bacterial test and rodent injection studies.

According to [108], polyvinyl pyrrolidone may be harmful after swallowing.

Some hazard statements assigned to polyvinyl pyrrolidone are presented in Table 4 .

Anderson et al. [109] investigated the impact of sodium alginate consumed by five male volunteers on their health. The ingestion of sodium alginate did not affect significantly hematological indices, plasma biochemistry parameters, urinalysis parameters, blood glucose and plasma insulin strengths, and breath hydrogen strengths. No allergic reactions occurred in any of the volunteers. The long term ingestion of sodium alginate at a high level induced no unwanted impacts.

Three pieces of information related to the toxicity of Arabic gum were found in literature. Some hazard statements assigned to the Arabic gum are presented in Table 4.

Abdelgadir [110] studied the effect of gum Arabic A. Senegal (Hashab), A. seyal (Talha), A. polyacantha (Kakmut), and Cyamopsis tetragonoloba (Guar gum) on blood glucose, total protein, lipid profile, and body weight. The mentioned types of gum Arabic and guar gum were free from toxic, diminishing blood glucose and body weight. All types of gum Arabic did not influence the total protein in the lipid profile. HDL enhanced for Hashab, Talha, and Kakmut, but it is not influenced by Guar. LDL diminished for Talha and enhanced for Hashab, but it is not influenced by Kakmut. TG enhanced for Hashab and diminished for Talha, Kakmut, and Guar. 
According to [111], gum Arabic is able to form combustible dust concentrations in air.

As reported in [112], gum Arabic causes serious eye damage/eye irritation.

Two pieces of information related to the toxicity of polyvinylidene fluoride were found in the literature. Some hazard statements assigned to polyvinylidene fluoride are presented in Table 4.

Inderherbergh [113] reported that polyvinylidene fluoride (PVDF or $\mathrm{PVF}_{2}$ ) is non-toxic.

However, according to [114], poly(vinylidene fluoride) induces skin irritation and serious eye irritation. It also may induce respiratory irritation.

Frischmann et al. [6] pointed that PVP blends with Nafion, PAMAM dendrimers, polycationic -cyclodextrins, poly(acrylic acid), poly-(ethylene oxide), and carboxymethyl-cellulose: styrenebutadiene-rubber (CMC:SBR), and can be used as the binders increasing the cathode efficiency.

Three pieces of information were found related to the toxicity of Nafion. Some hazard statements assigned to Nafion are presented in Table 4.

Feng et al. [115] described the Nafion 117 membrane (N117), a polymer electrolyte membrane (PEM) utilized for different chemical technologies. They carried out studies on the histopathological alterations, oxidative stress biomarker responses, and transcriptome profiles in the liver of male mice exposed to N117 and its combustion products for 24 days. Several highly altered molecular pathways, such as the metabolism of xenobiotics, carbohydrates, and lipids were identified.

According to [116], the thermal decomposition vapours of fluorinated plastics such as Nafion cast membranes may induce polymer fume fever with flu-like symptoms in humans. Such symptoms may be delayed. Repeated cases of polymer fume fever may cause persistent lung effects. Inhalation of fluorinated compounds may induce lung irritation and pulmonary oedema. Touch with the mentioned product may induce mechanical irritation of eyes and skin irritation.

As reported in [117], Nafion induces skin irritation and serious eye irritation. It may induce respiratory irritation.

Two pieces of information related to the toxicity of PAMAM dendrimers were found in the literature. Some hazard statements assigned to PAMAM dendrimers are presented in Table 4.

According to [118], PAMAM is a highly flammable liquid and vapor. It is toxic after swallowing or inhalation, in touch with skin. It also induces damage to organs.

Albertazzi et al. [119] reported that cell internalization properties and diffusion of G4 and G4-C12 modified PAMAM dendrimers in primary neuronal cultures and in the CNS of animals. G4-C12 PAMAM dendrimer induced apoptotic cell death of neurons in vitro. In contrast, G4 PAMAM induced no apoptotic cell death of neural cells in the sub-micromolar range of strength and induced weak microglia activation in the brain tissue.

It was difficult to clearly determine the toxicity of polycationic cyclodextrins (CDs).

Cryan et al. [120] tested polycationic cyclodextrins (CDs) complexed with plasmid DNA on the COS-7 cells. These CDs were modified with pyridylamino, alkylimidazole, methoxyethylamino or primary amine groups at 6-positions of the glucose units. The polycationic CDs neutralised DNA to form stable nanoparticulate complexes. The transfection efficiency of these CDs was high for the present substituents with either an amino, pyridylamino, or butylimidazole group at the 6-positions and unmodified 2- and 3-hydroxyls. These CDs were good promoters of DNA cellular-uptake, the most efficient surpassing DOTAP. The uptake was affected by proteoglycan-mediated binding to the cells. The intracellular trafficking but not cellular uptake was the rate-limiting step in the transfection process.

Varan et al. [121] compared the potential of polycationic, amphiphilic cyclodextrin NPs to non-ionic amphiphilic cyclodextrins and core-shell type cyclodextrin NPs for paclitaxel delivery to breast tumors. All blank cyclodextrin NPs were non-cytotoxic against the L929 mouse fibroblast cell line. The paclitaxel-loaded NPs had a significant anticancer effect against the MCF-7 human breast cancer cell line in comparison to a paclitaxel solution in DMSO.

Gerloczy et al. [122] reported that the complexation of cholesterol and of bile acids by cyclodextrin derivatives had a little impact on the excretion of cholesterol from the gastrointestinal tract. The various untoward impacts occurred after chronic large oral doses of hydroxypropyl $\beta$-cyclodextrin that are 
administered were not induced by increased excretion of some vital lipophile or enzyme but resulted from the solubilization and increased absorption of toxic contaminants of the ingested food.

Two studies related to toxicity of acrylic acid were found.

According to [123], poly(acrylic acid) (PAA) and poly(sodium acrylate) (NaPAA) are used as a food additive, due to their low toxicity.

As reported in [124], acrylic acid is used in the production of acrylic esters, as a monomer for polyacrylic acid and salts, and as a co-monomer with acrylamide for polymers used as flocculants, with ethylene for ion-exchange resin polymers, with methyl ester for polymers, and with itaconic acid for other co-polymers. The acrylic acid induced low to moderate acute toxicity by the oral route and moderate acute toxicity by the inhalation and dermal routes. The acrylic acid was corrosive or irritant to the skin and eyes and strongly irritant to the respiratory tract. This acid was not teratogenic and had no adverse impacts on reproduction.

There was no direct information related to the toxicity of carboxymethyl-cellulose: styrenebutadiene-rubber (CMC:SBR).

However, according to [125], carboxymethyl cellulose is able to form combustible dust concentrations in air.

Mondal and Yeasmin [126] evaluated the sub-chronic oral toxicity of food-grade carboxymethyl cellulose in Swiss albino mice. No treatment-related abnormality in terms of haematological and biochemical parameters was found. Water intake, urine production, and urinary sodium excretion increased with the increase of CMC doses. The weekly body weight did not vary significantly. No abnormalities in the histopathology of liver, heart, lung, and kidney occurred.

Patterson et al. [127] reported a case of a woman that experienced anaphylaxis following endangering to carboxymethyl cellulose.

Healy [128] reported studies on the carboxymethyl cellulose effects on inflammation, microbiota-related metabolic syndrome, and colitis.

Martino et al. [129] reported that carboxymethyl cellulose causes inflammation of the gut, altering microbiota, and is a triggering factor of inflammatory bowel diseases such as ulcerative colitis and Crohn's disease.

Fieldturf Tarkett [130] pointed that styrenebutadiene-rubber can be safely used both for people and milieu.

The use of polytetrafluoroethylene (PTFE) composites-carboxymethyl cellulose (CMC) as a binder increases the cell capacity and load of sulfur compared to polyvinyl pyrrolidone (PVP) and PTFE-polyvinyl alcohol (PVA) composite used as binders [131], but no cyclic performance is reported. The capacity can increase when a PTFE-CMC composite is used as a binder [132]. Jung and Kim [133] reported that the discharging capacity and cyclability performance can be increased using a combination of PVP and polyethylene imine (PEI) compared to a single component PVP binder. The chemical reaction between PVP and PEI increases the stability of the PVP-PEI composite in the electrolyte, resulting in a good mechanical strength of the cathode.

Gelatin can also be a binder for a sulfur cathode.

The cathodes using gelatin as a binder have a higher initial and cyclic capacities than those using PEO as a binder [95,134-136]. Gelatin shows the high stability in electrolytes, effective adhesion, and dispersion of cathode materials.

Li et al. [103] reported that an Acacia Senegal, GA—based binder was being non-toxic and balanced for high-performance Li-S cells.

Three pieces of information were found related to the toxicity of PTFE.

Sajid and Ilyas [137] reported that PTFE-coated cookware releases various gases and chemicals of mild to severe toxicity. The toxicity and fate of ingested PTFE coatings remain not clear. The well-known toxic environmental pollutant Perfluorooctanoic acid (PFOA) is also used in the synthesis of PTFA. The PFOA can occur in the gas phase released from the cooking utensils under normal cooking temperatures. Due to toxicity concerns, PFOA is replaced with GenXs, but these alternatives can also 
have similar toxicity. Therefore, more studies are needed on the human endangering and toxic impacts to PTFE, PFOA, and GenX as well as other alternatives.

Shimizu et al. [138] stated that PTFE can cause flu-like symptoms in humans-polymer fume fever.

According to [139], polytetrafluoroethylene is of low oral toxicity, but ingestion can cause gastrointestinal tract irritation. Dust and vapors or fumes that evolved during thermal processing can induce irritation of the respiratory system. It can induce irritation of skin and eyes. It is of low toxicity to aquatic organisms.

Three pieces of information were found related to the toxicity of polyvinyl alcohol.

BrookeTaylor and Verger [140] reported no apparent toxic or carcinogenic effects in studies concerning polyvinyl alcohol as a whole, the very poor absorption of preparations of polyvinyl alcohol complying with the specification after oral administration, and no impacts on the gastrointestinal tract in the long term study in rats.

According to [141], orally administered PVA was relatively harmless. The acute oral toxicity of PVA was very low. The orally administered PVA was very poorly absorbed from the gastrointestinal tract and did not accumulate in the body. The PVA was not mutagenic or clastogenic.

As reported in [142], polyvinyl alcohol may be harmful if inhaled or swallowed. It can induce irritation of respiratory tract, skin, and eyes.

Some other modern binders were characterized below.

Peled et al. [143] analyzed the electrochemical behavior, during prolonged cycling, of $\mathrm{Li}_{2} \mathrm{~S}$-based cathodes containing different binders, such as poly(vinylidene fluoride) (PVDF-HFP), polyvinyl pyrrolidone (PVP), mix of PVP with polyethyleneimine (PEI), polyaniline (PANI), and lithium polyacrylate (LiPAA).

As reported in [144], PVDF-HFP may be harmful after inhalation or swallowing. It may induce irritation of respiratory tract, skin, and eyes.

According to [145], polyethyleneimine induces serious eye irritation. It is harmful after swallowing. It may induce an allergic skin reaction. It is also toxic to aquatic life with long lasting effects.

Three pieces of information were found related to the toxicity of polyaniline.

According to [146], polyaniline may induce irritation of skin and eyes.

Ibarra et al. [147] appraised the acute toxicity impacts of polyaniline nanoparticles (PANI-Np) in different dispersants on embryos and larvae of Rhinella arenarum. The $\mathrm{LC}_{50}$ of PANI-Np dispersed in polyvinylpyrrolidone (PVP) was equal to $1.5 \mathrm{~g} / \mathrm{L}$, while $\mathrm{LC}_{50}$ by PANI-Np dispersed in PVP+PNIPAM (polyN-isopropylacrilamide) exhibited a highest toxicity $(1.17 \mathrm{~g} / \mathrm{L})$. The embryo teratogenicity enhanced with the increase of the exposure strength in both kinds of PANI-Np although PANI-Np1 showed an enhanced teratogenic impact affected by the polymer stabilizer PVP.

Humpolíček et al. [148] demonstrated the biocompatibility of macroporous polyaniline cryogel through the cytotoxicity test on mouse embryonic fibroblasts and through the embryotoxicity test utilizing the creation of beating foci within spontaneous differentiating embryonic stem cells.

Some information related to the toxicity of lithium acrylate were also found. Some hazard statements assigned to lithium acrylate were presented in Table 4.

He et al. [149] proposed a 'water-in-ionomer' type of electrolyte. Therein, organic solvents were replaced by water and toxic fluorinated Li salts by a non-fluorinated and non-toxic ionomer, Li polyacrylate.

According to [150], the aqueous-based binder systems are milieu friendly and non-toxic, and they can replace PVDF. The authors utilized aqueous-based binders (LiPAA and NaCMC).

As reported in [151], lithium polyacrylate is harmful after swallowing.

Zhang [152] proposed a poly(acrylamide-co-diallyl dimethyl ammonium chloride) (AMAC) as the cationic polyelectrolyte binder of high S loading cathodes. 
Table 4. Hazard statements of polyvinyl pyrrolidone, gum Arabic, polyvinylidene fluoride, Nafion, PAMAM dendrimers, polyethyleneimine, lithium polyacrylate, and AMAC.

\begin{tabular}{ccc}
\hline Material & Class of EC 1272/2008 & References \\
\hline polyvinyl pyrrolidone & $\mathrm{H} 303$ & {$[108]$} \\
gum Arabic & $\mathrm{H} 319$ & {$[112]$} \\
polyvinylidene fluoride & $\mathrm{H} 315, \mathrm{H} 319, \mathrm{H} 335$ & {$[114]$} \\
Nafion NR50 & $\mathrm{H} 315, \mathrm{H} 319, \mathrm{H} 335$ & {$[117]$} \\
PAMAM dendrimers & $\mathrm{H} 225, \mathrm{H} 301, \mathrm{H} 311, \mathrm{H} 331, \mathrm{H} 370$ & {$[118]$} \\
polyethyleneimine & $\mathrm{H} 319, \mathrm{H} 302, \mathrm{H} 317, \mathrm{H} 411$ & {$[145]$} \\
lithium polyacrylate & $\mathrm{H} 302$ & {$[151]$} \\
AMAC & $\mathrm{H} 412$ & {$[153]$} \\
\hline
\end{tabular}

H225—Highly flammable liquid and vapour; H311—Toxic in contact with skin; H317-May cause an allergic skin reaction; H412-Harmful to aquatic life with long-lasting effects.

According to [153], poly(acrylamide-co-diallyl dimethyl ammonium chloride) is harmful to aquatic life with long lasting impacts. Some hazard statements assigned to poly(acrylamide-co-diallyl dimethyl ammonium chloride) (AMAC) were presented in Table 4.

Exon [154] reported that acrylamide proved to be a neurotoxicant, reproductive toxicant, and carcinogen in animal species. Just the neurotoxic effects occurred in humans and just at high levels of endangering in occupational settings.

Additionally, as reported in [155], the diallyldimethylammonium chloride (DADMAC) is harmful after swallowing. It induces burns and a risk of serious damage to the eyes. It is very toxic to aquatic organisms.

Hwa et al. [156] proposed a redox-active supramolecular polymer binder. It used a perylenebisimide (PBI) scaffold presenting four carboxylic acid moieties lithiatable by treatment with $\mathrm{LiOH}$.

Frischmann et al. [96] used the stacked perylenebisimide (PBI) molecules as strongly networked, redox-active supramolecular polymer binders in $\mathrm{S}$ cathodes for Li-S cells.

No information related directly to the toxicity of direct perylenebisimide (PBI) was found in literature.

Jiao et al. [157] obtained a multi-functional polar binder (AHP) by polymerization of hexamethylene diisocyanate (HDI) with ethylenediamine (EDA) bearing many amino groups, which were applied to electrode creation with $S$ powder cathodes.

Wang et al. [158] stated that hexamethylene diisocyanate (HDI) is aliphatic that may induce less toxicity.

Cary et al. [159] reported that EDA shows moderate acute toxicity in animals. It is a primary irritant, being corrosive when undiluted, and is a skin sensitizer.

Cheng et al. [160] prepared a sulfonated polystyrene (SPS) binder via an homogeneous reaction.

Rogers and $\mathrm{Li}$ [161] reported that swallowing of sulfonated polystyrene often caused intestinal disturbances such as loss of appetite, nausea, vomiting, and constipation. In rare cases, they were accompanied by colonic necrosis.

\subsection{Electrolyces}

The electrolyte is also a significant part of the Li-S cell. Each component of the electrolyte affects the cell performance $[55,162,163]$.

\subsubsection{Liquid Electrolytes}

Liquid electrolytes comprise Li salts dissolved in organic solvents. 


\section{Ether-Based Electrolytes}

Actually, the ether-based electrolyte is usually applied in the Li-S cell. It consists of $1 \mathrm{M}$ amidium bis-trifluoromethanesulfonimide (LiTFSI) in a binary ether solvent 1,2-dimethoxyethane (DME) and 1,3-dioxolane (DOL) with a small volume of $\mathrm{LiNO}_{3}$ as additive [24,164-166]. Ether solvents have a good stability in contact with polysulfides (PS) [167-169] and strong ion conductivity and stronger electrolyte/electrode contact due to weak viscosity and good wettability [165].

According to [170], LiTFSI is toxic in touch with skin and after swallowing, induces severe skin burns and eye damage. It is also harmful to aquatic life with long lasting impacts.

As reported in [171], dimethyl ether can affect a man when breathed in. Vapor can induce eye, nose, and throat irritation. High endangering can induce headache, dizziness, light-headedness, and loss of consciousness. During skin touch it can induce severe frostbite.

According to [172], dimethyl ether is an extremely flammable gas. It usually is stored under pressure and is able to explode if heated. It may induce drowsiness or dizziness.

As reported in [173], dioxolane showed mild toxicity by oral administration or by inhalation. After acute endangering to high levels, reversible CNS depression occurred. After repeated-dose or subchronic administration, impacts on the blood-forming systems such as a reduction in WBCs and platelets and changes in spleen weight occurred in rats. Dioxolane had a low genotoxic potential.

According to [174], 1,3-dioxolane is a highly flammable liquid and vapor. It induces serious eye irritation.

Some hazard statements assigned to LiTFSI, dimethyl ether, and 1,3-dioxolane were shown in Table 5.

Table 5. Hazard statements of LiTFSI, dimethyl ether, and 1,3-dioxolane.

\begin{tabular}{ccc}
\hline Material & Class of EC 1272/2008 & References \\
\hline LiTFSI & H301, H311, H314, H373, H412 & {$[170]$} \\
dimethyl ether & H220, H280, H336 & {$[172]$} \\
1,3-dioxolane & H225, H319 & {$[174]$}
\end{tabular}

H220—Extremely flammable gas; H280—Contains gas under pressure; may explode if heated; H336-May cause drowsiness or dizziness; H373-May cause damage to organs through prolonged or repeated exposure.

Solvents

Many studies were carried out on one-component, two-component, and even ternary solvents with Li salts. One-component solvents comprise THF [175-177], dimethoxyethane (DME) [178], 1,3-dioxolane (DOL) [132], tri (ethylene glycol) dimethyl ether (triglyme) [179], tetra (glycol ethylene) dimethyl ether (TEGDME) [132,179,180], and polyethylene glycol dimethyl ether (PEGDME) [179]. A one-component solvent cannot meet all three electrolyte conditions [132].

A chain ether such as DME, polyethylene glycol dimethyl ether (PEGDME), and ethylene glycol dimethyl ether (TEGDME) are usually utilized as a single solvent in Li-S cells $[57,176,181,182]$.

A mixture of DOL and DME exhibits a good cyclability performance [183]. Polymerization DOL can protect the $\mathrm{Li}$ anode.

According to [184], also 2-Ethoxyethylether (EEE) was used as the solvent in Li-S cells.

Wang et al. [134] utilized five compositions of DME electrolyte: DOL $=4: 1,2: 1,1: 1,1: 2$, and 1:4 as a solvent and $\mathrm{LiClO}_{4}$ as the $\mathrm{Li}$ salt.

Barghamadi [185] used dimethyleneglycol dimethyl ether (DEGDME) possessing a glyme structure as a solvent in Li-S cells.

Barchasz et al. [186] utilized different kinds of solvents for Li-S cells, such as a binary solvent containing TEGDME and DOL in a various volume ratio and also a single TEGDME or DOL.

Kim et al. [187] studied the ternary diglyme system (DGM) -DOL-DME.

The unwanted phenomenon of PS transfer can be limited through the addition of an adsorbent to a cathode or utilizing a PEGDEG-based electrolyte [179,188]. 
Two pieces of information related to the toxicity of THF were found in the literature. Some hazard statements assigned to THF were shown in Table 6.

According to [189], THF was a polar solvent and monomer easily absorbed by each route of endangering. The THF exhibited low to moderate acute toxicity by each route. Direct touch with it can cause irreversible corrosive damage to the eyes. Nevertheless, THF was neither a skin irritant, nor sensitizer.

As reported in [190], tetrahydrofuran (THF) is a highly flammable liquid and vapor. It is harmful after swallowing. It induces serious eye irritation and may induce respiratory irritation. It is also suspected to induce cancer.

Moreover, two pieces of information related to the toxicity of ethylene glycol were found in literature. Some hazard statements assigned to ethylene glycol were shown in Table 6.

According to [191], ethylene glycol was poisoning when drinking. The initial symptoms were intoxication, vomiting, and abdominal pain. Later symptoms were a diminished level of consciousness, headache, and seizures. Long term outcomes could be kidney failure and brain damage. Toxicity and death can occur after drinking a minor dose.

As reported in [192], ethylene glycol is harmful after swallowing. It may induce damage to organs (kidney) via prolonged or repeated endangering.

According to [193], triethylene glycol was minimally irritating to the skin and eyes. In humans, triethylene glycol was not a skin sensitizer. Triethylene glycol did not exhibit teratogenic potential but could decrease fetal weights and delay skeletal growth in the offspring.

As reported in [194], the endangering to triethyleneglycoldimethylether (triglyme) induced irritation of the skin and eyes, abdominal pain, coughing, extrasystoles, nausea, and vomiting. This compound was harmful by inhalation, ingestion, or skin absorption. After heating to decomposition this compound emitted acrid smoke and irritating fumes containing $\mathrm{CO}$ and $\mathrm{CO}_{2}$. It caused irritation of the skin and eyes. It is able to damage the unborn child and is suspected of damaging fertility. This chemical is also combustible. Some hazard statements assigned to triglyme were shown in Table 6.

Some information related to the toxicity of DEGDME and TEGDME were found in literature. Some hazard statements assigned to them were shown in Table 6.

According to [195], DEGDME and TEGDME ethers were classified for reproductive toxicity.

As reported in [196], DEGDME is a flammable liquid and vapor. It is able to damage fertility or the unborn child.

According to [197], TEGDME is able to damage fertility or the unborn child.

Two pieces of information related to the toxicity of PEDGME were found in literature.

According to [198], PEGDME have high stability, retain their integrity during the anodization process, and have low toxicity.

As reported in [199], PEGDME may induce irritation of skin and eyes. It may be harmful after absorption through the skin, inhalation, or swallowing.

According to [200], the 2-ethoxyethyl ether is moderately toxic if ingested. It causes irritation of eyes. When heated to decomposition it emits acrid smoke and irritating fumes. Some hazard statements assigned to 2-Ethoxyethyl ether were shown in Table 6.

No data related to the toxicity of dimethyleneglycol dimethyl ether were found in literature. However, two pieces of information related to the toxicity of diglyme (DGM) were found. Some hazard statements assigned to diglyme were presented in Table 6.

According to [201], diglyme (DGM) exhibits the low acute toxicity after oral endangering or inhalation. Diglyme causes slight irritation of the skin or eyes. Diglyme is a strong teratogen.

As reported in [202], diglyme is a flammable liquid and vapor. It is able to damage fertility and is able to damage the unborn child.

Gillett et al. [203] informed that PEG exhibits the low toxicity and is utilized as an active ingredient of medical products such as laxatives and as a binder and lubricant in tablets. 
Schier et al. [204] reported that diethylene glycol (DEG) can result in renal and neurological toxicity if ingested.

Methyl acetate (MA), toluene, and gamma butyrolactone (GBL) affect the capacity and cyclability of Li-S cells [132,205]. Toluene can form a sure contact between electrode/electrolyte causing an improvement of both the initial capacity and the cyclability $[180,205]$. The addition of imidazolium salts into mixed DME-DOL electrolytes improved the cyclability by enhancing the electrochemical reaction of PSs and increasing the negative stability of the Li electrode [178]. Introduction of tetrabutylammonium hexafluorophosphate $\left(\mathrm{TBAPF}_{6}\right)$ to the electrolyte had a similar impact [133].

Two proper solvents for the electrolytes in Li-S cells are dimethyl ether (DME) and 1,3-dioxolane (DOL).

Two pieces of information related to the toxicity of methyl acetate were found in literature. Some hazard statements assigned to methyl acetate were presented in Table 6.

According to [206], methyl acetate irritated the mucous membranes of the respiratory tract in a man after short-term endangering and could be narcotic. Liquid methyl acetate irritated the eyes but not the skin.

As reported in [207], methyl acetate is a highly flammable liquid and vapor. It induces serious eye irritation and damage to organs such as eyes and the central nervous system. It may induce respiratory irritation, drowsiness, or dizziness.

Two pieces of information related to the toxicity of toluene were found in literature. Some hazard statements assigned to toluene were presented in Table 6 .

According to [208], toluene irritates the skin, eyes, and respiratory tract. It can induce systemic toxicity when ingested or inhaled and is slowly absorbed through the skin. The usual route of endangering is through inhalation. Symptoms of toluene poisoning can be the following: CNS effects (headache, dizziness, ataxia, drowsiness, euphoria, hallucinations, tremors, seizures, and coma), ventricular arrythmias, chemical pneumonitis, respiratory depression, nausea, vomiting, and electrolyte imbalances.

As reported in [209], toluene is a highly flammable liquid and vapor. It induces skin irritation. It is suspected of damaging fertility or the unborn child. It may induce drowsiness or dizziness, damage to organs such as central nervous system, liver, heart via prolonged or repeated endangering. It may be fatal after swallowing and enters airways. It is also harmful to aquatic life.

Two pieces of information related to the toxicity of GBL were found in literature. Some hazard statements assigned to GBL were presented in Table 6.

According to [210], there are some disadvantageous reactions to GBL. Signs and symptoms are the following: Euphoria, relaxation, decreased inhibition, and sedation progressing to vomiting, urinary and faecal incontinence, agitation, convulsions, bradycardia, respiratory depression, coma, and death.

As reported in [211], GBL may be harmful after inhalation, swallowing, or absorption through the skin. It induces burns of the eyes and skin.

Some information related to the toxicity of imidazolium salts were found in literature.

Cho et al. [212] studied 1-propyl-3-methylimidazolium [PMIM], 1-butyl-3-methylimidazolium [BMIM], 1-hexyl-3-methylimidazolium [HMIM], and 1-octyl-3-methylimidazolium [OMIM] with a bromide anion. Their toxicity decreased in the following order: $[\mathrm{OMIM}]>[\mathrm{HMIM}]>[\mathrm{BMIM}]>$ or $=[\mathrm{PMIM}]$. The $[\mathrm{OMIM}][\mathrm{Br}]$ was the most toxic to S. capricornutum. Although $[\mathrm{BMIM}][\mathrm{Br}]$ and [PMIM] [Br] were rather less toxic than [OMIM] and [HMIM], their toxicity enhanced with the elongation of the incubation time. Such ionic liquids may become more toxic after releasing into the freshwater ecosystem.

Biczak et al. [213] studied the impact of salts comprising the shared 1-ethyl-3-methylimidazolium [EMIM] cation as linked with: Bromide [Br], nitrate $\left[\mathrm{NO}_{3}\right]$, p-toluenesulfonate (tosylate) [Ts], dimethylphosphate [dMP], and methanesulfonate [MS] on the growth and progress of higher land plants-spring barley and common radish. They found the negative impact of Ionic Liquids (ILs) on the tested plants and the toxic impact of imidazolium salts was affected by the used ionic liquids strength. 
Some hazard statements assigned to tetrabutylammonium hexafluorophosphate and $\mathrm{LiCF}_{3} \mathrm{SO}_{3}$ were presented in Table 6.

According to [214], tetrabutylammonium hexafluorophosphate $\left(\mathrm{TBAPF}_{6}\right)$ may be harmful after inhalation or swallowing. It induces irritation of respiratory tract, skin, and eyes.

In [164], a study was reported on the influence of solvents with $1 \mathrm{M}$ lithium trifluoromethanesulfonate $\left(\mathrm{LiCF}_{3} \mathrm{SO}_{3}\right)$ on the efficiency of Li-S cells.

As reported in [215], $\mathrm{LiCF}_{3} \mathrm{SO}_{3}$ is thermally stable, non-toxic, and insensitive to moisture as compared with LiPF6.

Table 6. Hazard statements of tetrahydrofuran, ethylene glycol, triglyme, DEGDME, TEGDME, 2-ethoxyethyl ether, diglyme, methyl acetate, toluene, gamma-butyrolactone, $\mathrm{TBAPF}_{6}$, and $\mathrm{LiCF}_{3} \mathrm{SO}_{3}$.

\begin{tabular}{|c|c|c|}
\hline Material & Class of EC 1272/2008 & References \\
\hline Tetrahydrofuran & H225, Н302, Н319, Н335, Н351 & [190] \\
\hline ethylene glycol & H302, H373 & [192] \\
\hline Triglyme & H360Df & [194] \\
\hline DEGDME & H226, H360Df & [196] \\
\hline TEGDME & H360Df & [197] \\
\hline 2-ethoxyethyl ether & H227, Н319 & [200] \\
\hline Diglyme & H226, H360Df & [202] \\
\hline methyl acetate & Н319, Н335, Н336, Н370 & [206] \\
\hline Toluene & H225, Н315, Н361, Н336, Н373, Н304, H402 & [209] \\
\hline gamma-butyrolactone & H302, H318, H336 & [211] \\
\hline $\mathrm{TBAPF}_{6}$ & Н315, Н319, Н335 & [214] \\
\hline $\mathrm{LiCF}_{3} \mathrm{SO}_{3}$ & H315, Н319, Н335 & [216] \\
\hline
\end{tabular}

H226-Flammable liquid and vapor; H227-Combustible liquid; H304-May be fatal if swallowed and enters airways; H318-Causes serious eye damage; H360Df-May damage the unborn child. Suspected of damaging fertility; H402-Harmful to aquatic life.

However, as reported in [216], $\mathrm{LiCF}_{3} \mathrm{SO}_{3}$ induces irritation of skin and serious eye irritation. It may also induce respiratory irritation.

Lithium Salts

Zhu [217] stated that the kind of lithium salt in electrolytes strongly affects the proper operation of Li-S cells.

Until now, Lithium trifluoromethanesulfonate $\mathrm{LiSO}_{3} \mathrm{CF}_{3}$ (LiTf), Bis (Trifluoromethane) Sulfonimide Lithium Salt ( $\left.\mathrm{LiN}\left(\mathrm{SO}_{2} \mathrm{CF}_{3}\right)_{2}\right)$, and Lithium bis (trifluoromethane sulfonyl) imide (LiTFSI) are usually used in Li-S cells, ensuring stronger ionic conductivity and lower corrosion on the aluminium (Al) substrate $[165,218]$.

Moreover, LiTFSI and Li triflate $\mathrm{LiCF}_{3} \mathrm{SO}_{3}$ (LiTf) are often utilized in the Li-S cells [219-221].

Table 7 presented some hazard statements assigned to LiTf and $\mathrm{LiN}\left(\mathrm{SO}_{2} \mathrm{CF}_{3}\right)_{2}$.

According to [216] LiTf may induce irritation to the respiratory tract. It may be harmful after swallowing. It induces skin irritation and serious eye irritation.

As reported in [222], $\mathrm{LiN}\left(\mathrm{SO}_{2} \mathrm{CF}_{3}\right)_{2}$ is toxic after swallowing or in touch with skin. It induces severe skin burns and eye damage. It may induce damage to organs via prolonged periods or repeated endangering. It is also harmful to aquatic life with long lasting impacts.

The intermediate anode stability can be provided by bis (fluorosulfonyl) imide ( $\mathrm{Li}\left[\mathrm{N}\left(\mathrm{SO}_{2} \mathrm{~F}\right]_{2}\right)$, LiFSI) [223], and 4,5-dicyano-2-trifluoromethylimidazolide hydride (LiTDI) [224,225]. The Li perchlorate $\left(\mathrm{LiClO}_{4}\right)$ is also promising [134]. Kim and Jeong [163] studied $\mathrm{LiClO}_{4}$ and found its efficiency lower than that of LiTFSI or LiTf.

Two pieces of information related to the toxicity of bis (fluorosulfonyl) imide were found in literature. Table 7 presented some hazard statements assigned to bis (fluorosulfonyl) imide, LiTDI, and $\mathrm{LiClO}_{4}$. 
According to [226], bis (fluorosulfonyl) imide $\left(\mathrm{Li}\left[\mathrm{N}\left(\mathrm{SO}_{2} \mathrm{~F}\right]_{2}\right),(\mathrm{LiFSI})\right.$ is harmful after swallowing. It induces severe skin burns and eye damage. It is also able to damage fertility or the unborn child.

Table 7. Hazard statements of $\mathrm{LiSO}_{3} \mathrm{CF}_{3}, \mathrm{LiN}\left(\mathrm{SO}_{2} \mathrm{CF}_{3}\right)_{2}$, bis (fluorosulfonyl) imide, $\mathrm{LiTDI}$, and $\mathrm{LiClO}_{4}$.

\begin{tabular}{ccc}
\hline Material & Class of EC 1272/2008 & References \\
\hline $\mathrm{LiSO}_{3} \mathrm{CF}_{3}$ & $\mathrm{H} 315, \mathrm{H} 319, \mathrm{H} 335$ & {$[216]$} \\
$\mathrm{LiN}\left(\mathrm{SO}_{2} \mathrm{CF}_{3}\right)_{2}$ & $\mathrm{H} 301, \mathrm{H} 311, \mathrm{H} 314, \mathrm{H} 373, \mathrm{H} 412$ & {$[22]$} \\
bis (fluorosulfonyl) imide & $\mathrm{H} 314, \mathrm{H} 318$ & {$[227]$} \\
$\mathrm{LiTDI}_{\mathrm{LiClO}}$ & $\mathrm{H} 301, \mathrm{H} 315, \mathrm{H} 319, \mathrm{H} 335$ & {$[228]$} \\
& $\mathrm{H} 271, \mathrm{H} 272, \mathrm{H} 315, \mathrm{H} 319, \mathrm{H} 335$ & {$[229]$} \\
\hline
\end{tabular}

H271-May cause fire or explosion; strong oxidizer; H272-May intensify fire; oxidizer.

As reported in [227], bis (fluorosulfonyl) imide induces severe skin burns and eye damage.

According to [228], lithium 4,5-dicyano-2-trifluoromethylimidazolide hydride (LiTDI) is toxic after swallowing. It may induce irritation of skin and respiratory tract, and serious irritation of eyes.

Two pieces of information related to the toxicity of $\mathrm{LiClO}_{4}$ were found in literature.

As reported in [229], $\mathrm{LiClO}_{4}$ may induce fire or explosion and intensify fire. It induces skin irritation and serious eye irritation. It also may induce irritation of respiratory tract.

According to [230], accidental ingestion of the $\mathrm{LiClO}_{4}$ may be damaging to the human health. Lithium, in large doses, may induce dizziness and weakness. The endangering to perchlorates can induce shortness of breath, difficulty breathing, and a bluish discoloration of the skin. Nausea, vomiting, and diarrhea can appear after chlorate poisonings usually with upper stomach pain. The $\mathrm{LiClO}_{4}$ can induce eye irritation and damage, inflammation of the skin on touch, and respiratory irritation in humans. Long-term endangering to respiratory irritants may cause disease of the airways involving difficult breathing and related systemic problems.

\section{Electrolytes Based on Ionic Liquids}

Ionic liquid electrolytes can increase the initial discharging capacity and cyclic capacity (due to diminished PS dissolution) in comparison to these utilizing organic solvents such as polyethylene glycol dimethyl ether (PEGDME) or dimethyl carbonate (DMC) [231,232]. The combination of the organic solvent with liquid ionic electrolytes improves the cyclability Li-S cells [233].

Two pieces of information related to the toxicity of dimethyl carbonate were found in literature. Table 8 showed some hazard statements assigned to dimethyl carbonate.

As reported in [234], dimethyl carbonate is a highly flammable liquid and vapor.

Kuenen et al. [235] reported that dimethyl carbonate (DMC) received much attention due to its versatile use, low toxicity, and fast biodegradability.

Shahzad et al. [236] reported that ionic liquids (ILs) were not considered completely benign in terms of toxicity and degradability.

As the first, Yuan et al. [231] used pure Ionic liquids IL as a matrix electrolyte for Li-S cells. They elaborated ILN-methyl-N-butyl-piperi-bis (trifluoromethanesulfonyl) imide (PP14-RTIL) operating at room temperature, maintained by $1 \mathrm{M}$ LiTFSI.

No data directly related to N-methyl-N-butyl-piperi-bis (trifluoromethanesulfonyl) imide (PP14-RTIL) were found in literature. However, according to [237], 1-Butyl-1-methylpiperidinium bis (trifluoromethylsulfonyl) imide is toxic after swallowing or in touch with skin. It induces severe skin burns and eye damage.

Park et al. [238] compared two Li-S systems: The first one with 0.64 M LiTFSI IL electrolyte composed of tetravalent N, N-diethyl-N-methyl-N- (2-methoxyethyl) ammonium ammonia (DEME), and TFSI cations and the second one utilizing $0.98 \mathrm{M}$ LiTFSI added to the TEGDME electrolyte.

As reported in [239], diethylmethyl (2-methoxyethyl) ammonium bis (trifluoromethylsulfonyl) imide is not a hazardous substance or mixture. 
Wang et al. [232] confronted the operation of a composite S-cathode/mesoporous carbon in two Li-S cells: The first one utilizing an electrolyte composed of $1 \mathrm{M}$ 1-ethyl-3-methylimidazoliumbis (trifluoromethanesulfonyl) imide (EMIM TFSI)/LiTFSI and the second one with an electrolyte composed of 1 M LiTFSI/PEGDME. The IL electrolytes had both improved cyclability and discharging capacity due to the lower solubility of the PS in the IL-based electrolyte.

Two pieces of information related to toxicity of 1-ethyl-3-methylimidazoliumbis (trifluoromethanesulfonyl) imide were found in literature. Table 8 presented some hazard statements assigned to it.

According to [240], 1-ethyl-3-methylimidazoliumbis (trifluoromethanesulfonyl) imide is toxic if swallowed.

As reported in [241], an accidental ingestion of the 1-ethyl-3-methylimidazoliumbis (trifluoromethanesulfonyl) imide (EMIM TFSI) can damage the human health. Such a material can induce eye irritation and damage, inflammation of the skin on touch, and respiratory irritation in humans.

Tachikawa et al. [242] used the so-called 'quasi-IL' [LiG4] [NTf2] (G4 = tetraethyleneglycoldimethylether, TEGDME), complex electrolytes of molten aglyme-Li salts. The [LiG4]+ cation was an equimolar complex of G4 and Li+. The utilized cells with S supported on 3D ordered macroporous $\mathrm{C}$, as a cathode material.

No data related to the toxicity of [LiG4] [NTf2] were found in literature.

Yan et al. [243] selected the [P1A3] [TFSI] (P1A3Dn-methyl-N-Allylpyrrolidinium) for IL utilizing an $\mathrm{Si} / \mathrm{C}$ anode in place of metallic Li.

Table 8. Hazard statements of dimethyl carbonate, 1-butyl-1-methylpiperidinium bis(trifluoromethylsulfonyl)imide, 1-ethyl-3-methylimidazoliumbis (trifluoromethanesulfonyl) imide, 1-allyl-1-methylpyrrolidinium bis(trifluoromethanesulfonyl)imide, 1-ethyl-3-methylimidazolium bis(pentafluoroethylsulfonyl)imide, and 1-butyl-3-methylimidazolium hexafluorophosphate.

\begin{tabular}{ccc}
\hline Material & Class of EC 1272/2008 & References \\
\hline dimethyl carbonate & H225 & {$[234]$} \\
1-butyl-1-methylpiperidinium bis (trifluoromethylsulfonyl) imide & H301, H311, H314 & {$[237]$} \\
1-ethyl-3-methylimidazoliumbis (trifluoromethanesulfonyl) imide & H301 & {$[240]$} \\
1-allyl-1-methylpyrrolidinium bis (trifluoromethanesulfonyl) imide & H315, H319 & {$[244]$} \\
1-ethyl-3-methylimidazolium bis (pentafluoroethylsulfonyl) imide & H301 & {$[245]$} \\
1-butyl-3-methylimidazolium hexafluorophosphate & H315, H319 & {$[246]$} \\
\hline
\end{tabular}

No data related directly to the toxicity of [P1A3] [TFSI] (P1A3Dn-methyl-N-Allylpyrrolidinium) were found in literature. However, according to [244], 1-Allyl-1-methylpyrrolidinium Bis (trifluoromethanesulfonyl) imide induces skin irritation and serious eye irritation. Some hazard statements assigned to it are shown in Table 8.

Kim et al. [178] prepared the IL-organic mixture, adding various amounts of EMIMBETI imidazolium salts and $\mathrm{BMIMPF}_{6}$ to $0.5 \mathrm{M} \mathrm{LiTFSI}$ or $0.5 \mathrm{M} \mathrm{LiPF}_{6}$ to DOL:DME $(1: 4 v / v)$.

Table 8 presented some hazard statements assigned to 1-Ethyl-3-methylimidazolium bis (pentafluoroethylsulfonyl) imide and 1-Butyl-3-methylimidazolium hexafluorophosphate.

According to [245], 1-Ethyl-3-methylimidazolium bis (pentafluoroethylsulfonyl) imide [EMIM] BETI is toxic after swallowing.

As reported in [246], 1-Butyl-3-methylimidazolium hexafluorophosphate induces skin irritation and serious irritation of eyes.

\section{Carbonate-Based Electrolytes}

Carbonate solvents are not proper electrolytes for Li-S cell, however, PAN-S [247-249] or AC-S [250] composite electrodes provided very strong reversible capacities in mixtures: 
Ethylene carbonate-dimethyl carbonate (WE-DMC) $[69,247,248,251]$ or propylene carbonate-ethylene carbonate-diethyl carbonate (PC-EC-DEC) $[249,250]$ comprising $1 \mathrm{M} \mathrm{LiPF}_{6}$.

Zhang et al. [252] used $1 \mathrm{M} \mathrm{LiPF}_{6}$ in PC/EC/DEC $(1: 4: 5 v / v / v)$ as the electrolyte for the S/C cathode spheres.

Two pieces of information related to the toxicity of acrylonitrile were found in literature.

Table 9 presented some hazard statements assigned to acrylonitrile $\left(\mathrm{CH}_{2}=\mathrm{CHCN}\right)$, ethylene carbonate, diethyl carbonate, propylene carbonate, and $\mathrm{LiPF}_{6}$.

According [253], acrylonitrile $\left(\mathrm{CH}_{2}=\mathrm{CHCN}\right)$ is a flammable liquid that is highly toxic after ingestion and is a known carcinogen. PAN is non-hazardous compared to the monomer.

Table 9. Hazard statements of acrylonitrile $\left(\mathrm{CH}_{2}=\mathrm{CHCN}\right)$, ethylene carbonate, diethyl carbonate, propylene carbonate, and $\mathrm{LiPF}_{6}$.

\begin{tabular}{ccc}
\hline Material & Class of EC 1272/2008 & References \\
\hline acrylonitrile $\left(\mathrm{CH}_{2}=\mathrm{CHCN}\right)$ & $\mathrm{H} 225, \mathrm{H} 301, \mathrm{H} 311, \mathrm{H} 315, \mathrm{H} 317, \mathrm{H} 318, \mathrm{H} 331, \mathrm{H} 335, \mathrm{H} 350, \mathrm{H} 411$ & {$[254]$} \\
ethylene carbonate & $\mathrm{H} 302, \mathrm{H} 315, \mathrm{H} 318, \mathrm{H} 319, \mathrm{H} 335, \mathrm{H} 373$ & {$[255]$} \\
diethyl carbonate & $\mathrm{H} 226, \mathrm{H} 315, \mathrm{H} 319, \mathrm{H} 335$ & {$[256]$} \\
propylene carbonate & $\mathrm{H} 319$ & {$[257]$} \\
$\mathrm{LiPF}_{6}$ & $\mathrm{H} 302, \mathrm{H} 311, \mathrm{H} 314$ & {$[258]$} \\
\hline
\end{tabular}

As reported in [254], acrylonitrile is a highly flammable liquid and vapor. It is toxic after swallowing, inhalation, or in touch with skin. It induces irritation of skin and serious eye damage. It may induce an allergic skin reaction, respiratory irritation, and cancer. It is also toxic to aquatic life with long lasting impacts.

No data related directly to the toxicity of active carbon (AC) were found in literature.

According to [255], ethylene carbonate (EC) is harmful after swallowing. It induces irritation of skin and respiratory tract, and also serious eye damage. It also induces damage to organs through prolonged or repeated endangering.

As reported in [256], diethyl carbonate (DEC) induces irritation of skin and respiratory tract, and serious eye irritation. It is also a flammable liquid and vapor.

According to [257], propylene carbonate induces serious irritation of eyes.

As reported in [258], $\mathrm{LiPF}_{6}$ induces serious eye damage and severe skin burns. It is harmful after ingestion, has a strong corrosive impact on mouth and throat to the danger of perforation of oesophagus and stomach. It may induce irritation after inhalation.

\subsubsection{Solid Electrolytes}

Liu et al. [28] classified solid electrolytes in Li-S cells as polymer, gel, and glass/ceramic ones.

All-solid-state polymer electrolytes, [66,69] gel polymer electrolytes (GPEs; obtained by the hot-press, [69] phase inversion, [205,259] or electrospinning [260] approaches), glass-ceramic electrolytes, [70,261], and fast ionic conductors, [262-265] can be utilized in Li-S cells.

\section{Solid Polymer Electrolytes}

Solid polymer electrolyte (SPE) contains lithium salts added to a high molecular weight polymeric host functioning as solid solvents [266]. In the all-solid Li-S cell system, SPE limits dissolution and diffusion of PS, and also the transfer phenomenon, increasing the cyclability performance of the cell [267].

Poly (ethylene oxide) (PEO), PPO, PAN, PMMA, PVC, poly (vinylidene fluoride) (PVDF), and poly (vinylidene fluoride)-hexafluoropropylene (PVDF-HFP) can be a solid host due to high power of solvation and ion transport capacity. PEO based on PEO has the high solvation power, complexing ability, and ion transport mechanism, directly affected by alkaline Li salts [268]. 
According to [269], polyphenylene ether (PPO) is available as pellets with a slight or no odor. Such a material is able to burn in a fire creating toxic smoke. As a molten, plastic can induce severe thermal burns. Its fumes produced during melt processing may induce irritation of eyes, skin, and respiratory tract. Severe over-endangering may cause nausea, headache, chills, and fever. Its mechanical operations can produce dust causing an explosion or respiratory hazard.

Manoukian et al. [270] reported that PMMA has great mechanical properties and low toxicity.

According to [271], PVC contains chemicals with adverse impacts to the human health. Endangering to such a material often results in contact with phthalates and chlorine. Manufacturing, burning, or landfilling PVC releases dioxins. Phthalates, dioxins, and BPA can be endocrine disruptors.

As reported in [272], as a solid or dust, PVDF causes irritation or corneal injury due to mechanical action. It is essentially not irritating to the skin. It may induce mechanical injury only. As a molten material, it is able to burn skin. Its dust may induce irritation to the upper respiratory tract.

According to [273], PVDF-HFP is not a health hazard substance. No specific health hazards are known. However, its dust may induce irritation of eyes and the respiratory tract. Prolonged contact may induce dryness of the skin.

Weston and Steele [274] combined $\mathrm{LiClO}_{4}, \mathrm{LiTFSI}, \mathrm{LiBF}_{4}$, and $\mathrm{LiPF}_{6}$ with PEO.

Liu et al. [28] reported the polymer electrolytes composed of Li salts in PEO.

Jeon et al. [275] tested the PEO-LiClO 4 combination as an electrolyte for the $\mathrm{Li}-\mathrm{S}$ cell. Due to the poor ionic conductivity at room temperature, the PEO-LIX electrolytes are not proper for the Li-S cells. Such a problem can be resolved using the inorganic ceramic fillers, such as $\mathrm{SiO}_{2}, \mathrm{TiO}_{2}$, $\mathrm{ZrO}_{2}, \mathrm{Al}_{2} \mathrm{O}_{3}$, and $\mathrm{LiAlO}_{2}$ in the polymer matrix of the host, to improve the ionic conductivity of the SPE [63-66,276-281].

Two pieces of information related to the toxicity of $\mathrm{SiO}_{2}$ were found in literature.

Sergent et al. [282] reported that $\mathrm{SiO}_{2}-25$ and $\mathrm{SiO}_{2}-100 \mathrm{~nm}$ induced a rather limited cytotoxic and genotoxic impacts on HT-29 cells after a $24 \mathrm{~h}$ exposure. However, inverse dose-dependent relationships occurred for $\mathrm{SiO}_{2}-100 \mathrm{~nm}$ NPs. The higher the dose of $\mathrm{SiO}_{2}-100 \mathrm{~nm}$ related to the weaker the cytotoxic/genotoxic impacts.

According to [283], $\mathrm{SiO}_{2}$ induces serious irritation of eyes and respiratory irritation. It also may induce damage to organs (lung) through prolonged or repeated endangering (if inhaled).

According to [36], $\mathrm{TiO}_{2}$ may induce irritation of eyes and skin. It exhibits low toxicity after ingestion and can induce irritation when inhaled. It can also induce cancer.

Two pieces of information related to the toxicity of $\mathrm{ZrO}_{2}$ were found in literature.

Arefian et al. [284] found that $\mathrm{ZrO}_{2}$ increased ROS generation and the ROS induced the generation of free radicals in turn. Those free radicals induced damage to different tissues. Following, to damage to the liver, its enzymes leaked into the bloodstream excessively.

According to [285], $\mathrm{ZrO}_{2}$ may induce irritation of eyes and skin. It may induce irritation when inhaled or ingested. It is also of a low aquatic toxicity.

As reported in [286], $\mathrm{Al}_{2} \mathrm{O}_{3}$ causes serious irritation of eyes and damage to organs through prolonged or repeated endangering. It may induce irritation of respiratory tract.

According to [287], $\mathrm{LiAlO}_{2}$ may induce irritation of eyes and skin. The irritation can occur after ingestion or inhalation.

Table 10 presented some hazard statements assigned to $\mathrm{SiO}_{2}, \mathrm{TiO}_{2}$, and $\mathrm{Al}_{2} \mathrm{O}_{3}$.

Table 10. Hazard statements of $\mathrm{SiO}_{2}, \mathrm{TiO}_{2}$, and $\mathrm{Al}_{2} \mathrm{O}_{3}$.

\begin{tabular}{ccc}
\hline Material & Class of EC 1272/2008 & References \\
\hline $\mathrm{SiO}_{2}$ & $\mathrm{H} 319, \mathrm{H} 335, \mathrm{H} 373$ & {$[283]$} \\
$\mathrm{TiO}_{2}$ & $\mathrm{H} 351$ & {$[36]$} \\
$\mathrm{Al}_{2} \mathrm{O}_{3}$ & $\mathrm{H} 319, \mathrm{H} 335, \mathrm{H} 372$ & {$[286]$} \\
\hline
\end{tabular}


The cyclability of Li-S cell with polymer electrolyte can be increased by the use of a $\mathrm{PEO}_{20} \mathrm{LiCF}_{3} \mathrm{SO}_{3}-\mathrm{ZrO}_{2}$ membrane smelled with $1 \mathrm{M} \mathrm{LiPF}_{6}$ and a saturated $\mathrm{Li}_{2} \mathrm{~S}$ solution in EC-DMC $[68,69,251]$.

The addition of $\mathrm{ZrO}_{2}$ to the electrolyte in Li-S cell was reported in $[68,288,289]$. Liang et al. [290] utilized PEO 18LiTFSI-10 $\mathrm{wt} \% \mathrm{SiO}_{2}$ as an electrolyte with a mesoporous $\mathrm{C}$ sphere with homogenous channels (OMC) supporting $S$ as a cathode.

No data related directly to the toxicity of $\mathrm{PEO}_{20} \mathrm{LiCF}_{3} \mathrm{SO}_{3}-\mathrm{ZrO}_{2}$ were found in literature.

Gel Polymer Electrolytes

$\mathrm{Xu}$ and Ye [291] elaborated the gel polymer electrolyte (GPE) containing the liquid component tightly trapped in the polymer matrix.

The polymer films utilizing PEO, PVDF, and PVDF-HFP can be used in Li-S cells [69,249,292-295].

Wang et al. studied a gel electrolyte poly (vinylidene fluoride-hexafluoropropylene) (PVDF-HFP) with plasticizers, such as EC-DMC and PC-EC-DEC at room temperature. The ionic conductivity was stronger than that for a PEO-based polymeric electrolyte. A strong discharging capacity and load of $\mathrm{S}$ are received with PAN-S [248,249] and C-S [247,250] electrodes. The combination of PVDF [294] or PVDF-HFP with TEGDME as a plasticizer [175] resulted in a poor use of sulfur. Combining TEGDME with EC as a plasticizer for PVDF-HFP microporous gel electrolytes allowed an improvement of Li-S cells [65].

Ryu et al. [294] combined a polymer matrix utilizing PVDF with LiTf/tetraglymeas electrolyte for Li-S cells.

No data directly related to the toxicity of EC-DMC, PC-EC-DEC and TEGDME-EC were found in literature.

According to [296], tetraethylene glycol dimethyl ether (tetraglyme) is able to damage fertility or the unborn child. Some hazard statements assigned to tetraglyme are shown in Table 11.

Hassoun and Scrosati [69] reported a metallic system without mercury using the Sn/C anode and the $\mathrm{Li}_{2} \mathrm{~S} / \mathrm{C}$ cathode. They utilized a gel-type polymer membrane produced by the capture of $\mathrm{LiPF}_{6} / \mathrm{EC}: \mathrm{DMC}$ in a $\mathrm{PEO} / \mathrm{LiCF}_{3} \mathrm{SO}_{3}$ polymer matrix as an electrolyte with a dispersed ceramic zirconium filler as an additive.

As reported in [297], the organic tin bonds are very dangerous for humans. The relatively short hydrogen bonds of triethyltin makes it much dangerous for human health than a tin substance with longer hydrogen bonds. Humans can absorb tin bonds via food and breathing and via the skin. Tin induces irritation of eyes and skin, headaches, stomach-aches, sickness and dizziness, severe sweating, breathlessness, urination troubles. It may also induce long-term impacts such as depressions, liver damage, malfunctioning of immune systems, chromosomal damage, shortage of red blood cells, brain damage (causing anger, sleeping disorders, forgetfulness, and headaches).

According to [298], zirconium compounds are generally considered to be of low toxicity

Liu et al. [299] prepared a pentaerythritol tetraacrylate (PETEA)-based gel polymer electrolyte. The acrylate-based gel polymer electrolyte was in situ gelated into a polymethyl methacrylate (PMMA)-based electrospun nanofiber network. The structural and synergetic conformity between the nanofiber network and gel polymer electrolyte allowed a high uptake ability and a high ionic conductivity of the electrolyte, accompanied by an ester-rich structure, resulted in the high electrochemical performances [300].

Two pieces of information related to the toxicity of pentaerythritol triacrylate were found in literature. Some hazard statements assigned to pentaerythritol triacrylate are presented in Table 11.

As reported in [301], pentaerythritol triacrylate caused skin papillomas in the genetically modified mouse model used in these studies.

According to [302], pentaerythritol triacrylate induces skin irritation and serious eye irritation. It may induce an allergic skin reaction. 


\section{Non-Polymer Electrolytes}

Non-polymer electrolytes are suitable for all-solid Li-S cells, due to high thermal and chemical stability of the Li anode in the ambient atmosphere [303-306]. Different inorganic semiconductor electrolytes such as phosphates of the LiSICON type, perovskite type $\mathrm{La}_{(2 / 3) \times} \mathrm{Li}_{3 x} \mathrm{TiO}_{3}$ (LLT), $\mathrm{Li}_{3} \mathrm{~N}$, and $\mathrm{Li}_{4} \mathrm{SiO}_{4}[70,72,261,265,307]$ were investigated.

No data related to LiSICON and thio- LiSICON were found in literature.

According to [308], ionic conducting solid materials are non-toxic solid electrolytes. A family of the perovskite structure of $\mathrm{La}_{(2-3)-x} \mathrm{Li}_{3 \mathrm{x}} \mathrm{TiO}_{3}$ (hereafter abbreviated to LLTO) has the excellent $\mathrm{Li}$ ionic conductor. However, this information does not give enough information of non-toxicity of $\mathrm{La}_{(2-3)-x} \mathrm{Li}_{3 \mathrm{x}} \mathrm{TiO}_{3}$.

Two pieces of information related to the toxicity of $\mathrm{Li}_{4} \mathrm{SiO}_{4}$ were found in the literature. Some hazard statements assigned to $\mathrm{Li}_{4} \mathrm{SiO}_{4}$ are presented in Table 11.

According to information given in [309], $\mathrm{Li}_{4} \mathrm{SiO}_{4}$ may induce irritation of eyes, skin, and respiratory tract. Inorganic silicon compounds may be acute inhalation irritants. Prolonged inhalation may induce silicosis. Serious amounts of Li compounds may induce vomiting, diarrhea, ataxia, intestinal irritation, kidney injury, central nervous system suppression, and a drop in blood pressure.

As reported in [310], $\mathrm{Li}_{4} \mathrm{SiO}_{4}$ may induce respiratory irritation. It induces irritation of skin and eyes.

The family of sulphide compounds forming a solid amorphous electrolyte is the best known inorganic electrolyte in the solid state. Several studied on the glass electrolyte $\mathrm{Li}_{2} \mathrm{~S}_{-} \mathrm{P}_{2} \mathrm{~S}_{5}$ were reported in [71,311-314]. Agostini et al. [315] reported, that a solid-state $\mathrm{Li}-\mathrm{S}$ cell with the $\mathrm{Li}_{2} \mathrm{~S}-\mathrm{P}_{2} \mathrm{~S}_{5}$ electrolyte exhibited the enhanced specific energy, steadiness, and low-cost. Yamada et al. [316] found that in the all-solid-state $\mathrm{Li}-\mathrm{S}$ cell with a glass-type $\mathrm{P}_{2} \mathrm{~S}_{5}-\mathrm{Li}_{2} \mathrm{~S}$ electrolyte, the solid electrolyte component physically prevented PS migration.

The mechanically ground glass $\mathrm{Li}_{2} \mathrm{~S}-20 \mathrm{P}_{2} \mathrm{~S}_{5}(\mathrm{~mol} \%)$ had a very high conductivity at room temperature, due to the creation of $\mathrm{Li}_{7} \mathrm{PS}_{6}$ [317], described as "superionic" and crystallographic analogs of thio-LISICON [318].

Hayashi et al. [70] used the $\mathrm{Li}_{2} \mathrm{~S}-\mathrm{P}_{2} \mathrm{~S}_{5}$ ceramic electrolyte in the Li-S cell with the S/CuS cathode.

Nagao et al. [261] used a S/C composite electrode and $\mathrm{Li}_{2} \mathrm{~S}-\mathrm{P}_{2} \mathrm{~S}_{5}$ ceramic glass electrolyte.

No data related to the toxicity of $\mathrm{Li}_{2} \mathrm{~S}-\mathrm{P}_{2} \mathrm{~S}_{5}$ were found in literature.

According to [319], $\mathrm{Li}_{7} \mathrm{P}_{3} \mathrm{~S}_{11}$ containing the similar component as $\mathrm{Li}_{2} \mathrm{~S}-\mathrm{P}_{2} \mathrm{~S}_{5}$ can be toxic after swallowing or inhalation. It may induce severe skin burns and eye damage. It is very toxic to aquatic life. However, this information does not give enough information about non-toxicity of $\mathrm{Li}_{2} \mathrm{~S}-\mathrm{P}_{2} \mathrm{~S}_{5}$.

Recently, the related compound $\mathrm{Li}_{10} \mathrm{GeP}_{2} \mathrm{~S}_{12}$ was applied in the Li-S system [320].

Moreover, cells with anodes made of the $\mathrm{Li}$-In alloys and $\mathrm{Li}_{10} \mathrm{GeP}_{2} \mathrm{~S}_{12}$ as a fixed electrolyte were combined [321]. The cathode material was obtained by a mechanical-chemical treatment of a mixture of $\mathrm{Li}_{1.5} \mathrm{PS}_{3.3}, \mathrm{~S}$, and $\mathrm{C}$.

No data related to the toxicity of $\mathrm{Li}-\mathrm{In}$ alloy and to $\mathrm{Li}_{1.5} \mathrm{PS}_{3.3}$ were found in literature.

According to [322], $\mathrm{Li}_{10} \mathrm{GeP}_{2} \mathrm{~S}_{12}$ is harmful after swallowing. It may induce irritation of skin, eyes, and respiratory tract. Some hazard statements assigned to $\mathrm{Li}_{10} \mathrm{GeP}_{2} \mathrm{~S}_{12}$ are shown in Table 11.

The nanoporous $\beta-\mathrm{Li}_{3} \mathrm{PS}_{4}$ was reported in [323]. Nanometric $\mathrm{Li}_{2} \mathrm{~S}$ molecules coated with $\beta$-Li3PS4 were the active substance for the cathode described in [324].

Lin et al. [325] used a S-rich PS Li phosphate as the cathode for the Li-S cell utilizing a solid $\mathrm{Li}_{3} \mathrm{PS}_{4}$ electrolyte.

According to [326], $\beta-\mathrm{Li}_{3} \mathrm{PS}_{4}$ is toxic after swallowing and harmful after inhalation. It induces severe skin burns and eye damage. It is also very toxic to aquatic life.

As reported in [327], it is a flammable solid. In contact with water, it releases flammable gas. It is toxic after swallowing and harmful after swallowing or inhalation. It induces skin irritation and serious eye damage. It may induce respiratory irritation. It is also very toxic to aquatic life with long lasting effects. 
Some hazard statements assigned to $\beta-\mathrm{Li}_{3} \mathrm{PS}_{4}$ and $\mathrm{Li}_{3} \mathrm{PS}_{4}$ are presented in Table 11.

$\mathrm{Li}_{2} \mathrm{~S}-\mathrm{SiS}_{2}$ and $\mathrm{Li}_{2} \mathrm{~S}_{-} \mathrm{P}_{2} \mathrm{~S}_{5}$ ceramic glasses are suitable electrolytes in Li-S cells with all solid components. Conductivity increases by crystallization of $80 \mathrm{Li}_{2} \mathrm{~S} \cdot 20 \mathrm{P}_{2} \mathrm{~S}_{5}$ (mole\%) by mechanical grinding $[70,71,76]$. The high capacity was maintained for the use of $\mathrm{CuS}$ as a cathode, and metallic ion as a current collector for lithium deposition [312]. A glass $60 \mathrm{Li}_{2} \mathrm{~S} \cdot 40 \mathrm{SiS}_{2}$ electrolyte was reported in [73,74]. A $60 \mathrm{Li}_{2} \mathrm{~S} \cdot 40 \mathrm{SiS}_{2}$ glass electrolyte was reported in [312]. The lithium-ion conductors, such as thio-LISICON $\left(\mathrm{Li}_{3.25} \mathrm{Ge}_{0.25} \mathrm{P}_{0.75} \mathrm{~S}_{4}\right)$ and $3 \mathrm{Li}_{4} \mathrm{SiS}_{4} \cdot 0.5 \mathrm{La}_{2} \mathrm{~S}_{3}$ were reported in [328,329]. Kobayashi et al. [72] used a thio-LISICON as a solid electrolyte.

No data related to the toxicity of $80 \mathrm{Li}_{2} \mathrm{~S} \cdot 20 \mathrm{P}_{2} \mathrm{~S}_{5}, \mathrm{Li}_{2} \mathrm{~S}-\mathrm{SiS}_{2}, 60 \mathrm{Li}_{2} \mathrm{~S} \cdot 40 \mathrm{SiS}_{2}, 3 \mathrm{Li}_{4} \mathrm{SiS}_{4} \cdot 0.5 \mathrm{La}_{2} \mathrm{~S}_{3}$ and $\mathrm{CuS}$ were found in literature.

According to [330], $\mathrm{SiS}_{2}$ is fatal after swallowing. It induces skin irritation and serious eye irritation. It may induce respiratory irritation. Some hazard statements assigned to $\mathrm{SiS}_{2}$ are shown in Table 11.

As reported in [331], indium is toxic if more than a few milligrams are consumed and can affect the development of an embryo or fetus.

Table 11. Hazard statements of $\mathrm{Li}_{4} \mathrm{SiO}_{4}, \mathrm{Li}_{7} \mathrm{P}_{3} \mathrm{~S}_{11}, \mathrm{Li}_{10} \mathrm{GeP}_{2} \mathrm{~S}_{12}, \beta-\mathrm{Li}_{3} \mathrm{PS}_{4}, \mathrm{Li}_{3} \mathrm{PS}_{4}, \mathrm{SiS}_{2}$, and $\mathrm{Li}_{6} \mathrm{PS}_{5} \mathrm{Cl}$.

\begin{tabular}{ccc}
\hline Material & Class of EC 1272/2008 & References \\
\hline $\mathrm{Li}_{4} \mathrm{SiO}_{4}$ & $\mathrm{H} 315, \mathrm{H} 320$ & {$[310]$} \\
$\mathrm{Li}_{7} \mathrm{P}_{3} \mathrm{~S}_{11}$ & $\mathrm{H} 228, \mathrm{H} 260, \mathrm{H} 301, \mathrm{H} 302, \mathrm{H} 332, \mathrm{H} 314, \mathrm{H} 318, \mathrm{H} 400$ & {$[319]$} \\
$\mathrm{Li}_{10} \mathrm{GeP}_{2} \mathrm{~S}_{12}$ & $\mathrm{H} 302, \mathrm{H} 315, \mathrm{H} 319, \mathrm{H} 335$ & {$[322]$} \\
$\beta-\mathrm{Li}_{3} \mathrm{PS}_{4}$ & $\mathrm{H} 228, \mathrm{H} 260, \mathrm{H} 301, \mathrm{H} 314, \mathrm{H} 318, \mathrm{H} 332, \mathrm{H} 400$ & {$[326]$} \\
$\mathrm{Li}_{3} \mathrm{PS}_{4}$ & $\mathrm{H} 228, \mathrm{H} 261, \mathrm{H} 301, \mathrm{H} 302, \mathrm{H} 332, \mathrm{H} 315, \mathrm{H} 318, \mathrm{H} 335, \mathrm{H} 410$ & {$[327]$} \\
$\mathrm{SiS}_{2}$ & $\mathrm{H} 261, \mathrm{H} 300, \mathrm{H} 315, \mathrm{H} 319, \mathrm{H} 335$ & {$[330]$} \\
$\mathrm{Li}_{6} \mathrm{PS}_{5} \mathrm{Cl}$ & $\mathrm{H} 228, \mathrm{H} 260, \mathrm{H} 301, \mathrm{H} 314, \mathrm{H} 318, \mathrm{H} 332, \mathrm{H} 400$ & {$[332]$} \\
\hline
\end{tabular}

H261-In contact with water releases flammable gas; H300-Fatal if swallowed.

Han et al. [264] synthesized nanocomposites by dissolving $\mathrm{Li}_{2} \mathrm{~S}$ as the active material, polyvinylpyrrolidone (PVP) as the carbon precursor, and $\mathrm{Li}_{6} \mathrm{PS}_{5} \mathrm{Cl}$ as the solid electrolyte in ethanol. It was accompanied by coprecipitation and high-temperature carbonization processes. The obtained nanocomposites played simultaneous roles both of an active material and electrolyte. Using the $80 \mathrm{Li}_{2} \mathrm{~S} \cdot 20 \mathrm{P}_{2} \mathrm{~S}_{5}$ glass ceramic as the solid electrolyte in the composite electrode, good electrochemical efficiencies were reached.

According to [332], $\mathrm{Li}_{6} \mathrm{PS}_{5} \mathrm{Cl}$ is toxic after swallowing and harmful after inhalation. It induces severe skin burns and eye damage. It is also very toxic to aquatic life. Some hazard statements assigned to $\mathrm{Li}_{6} \mathrm{PS}_{5} \mathrm{Cl}$ are shown in Table 11 .

Wang et al. [263] investigated the all-solid-state electrolyte $\mathrm{Li}_{1+x} \mathrm{Ti}_{2-x} \mathrm{Al}_{x}\left(\mathrm{PO}_{4}\right)_{3}$ in contact with a PS solution and in Li-S cells.

No data related to the toxicity of $\mathrm{Li}_{1+x} \mathrm{Ti}_{2-\mathrm{x}} \mathrm{Al}_{\mathrm{x}}\left(\mathrm{PO}_{4}\right)_{3}$ were found in literature.

\subsubsection{Electrolyte Additives}

Several additions occurring in small amounts in the Li-S battery electrolytes are discussed below.

\section{Lithium Nitrates}

$\mathrm{LiNO}_{3}$ is the most common addition in the Li-S cell and its functions are described in [333]. The use of $\mathrm{LiNO}_{3}$ decreases an impedance of the $\mathrm{Li}$ film, and the products of its reduction $\mathrm{Li}_{x} \mathrm{NO}_{\mathrm{y}}$ can form an appropriate surface coating preventing reaction of Li with PS.

According to [334], contact with the $\mathrm{LiNO}_{3}$ material may induce irritation to skin, eyes, and mucous membranes. It may be toxic if ingested. Some hazard statements assigned to $\mathrm{LiNO}_{3}$ are shown in Table 12. 
Polysulphides

Polysulphides were also added to the Li-S electrolyte allowing the building of SEI anodes $[335,336]$. Xiong et al. [336] investigated the symmetric cells $\mathrm{Li} / \mathrm{Li}$ and $\mathrm{Li} / \mathrm{S}$ with $0.2 \mathrm{M} \mathrm{Li}_{2} \mathrm{~S}_{6}$ as a co-salt in electrolyte 0.8 M LiTFSI DOL:DME (1:1 v/v).

The long-chain PSs added to the electrolyte eliminated the formation of insoluble $\mathrm{Li}_{2} \mathrm{~S}_{2}$ and $\mathrm{Li}_{2} \mathrm{~S}$ within the carbon matrix and allowed the creation of a protective layer SEI on the Li electrode.

Xiong et al. [337] used the mixture of $\mathrm{LiNO}_{3}$ and $\mathrm{Li}$ PSs allowing the creation of the SEI film in Li-S cells. Such a SEI film had two sublayers. The dense bottom layer contained $\mathrm{Li}_{2} \mathrm{~S}_{2}, \mathrm{Li}_{2} \mathrm{~S}$, and $\mathrm{LiN}_{\mathrm{x}} \mathrm{O}_{\mathrm{y}}$. The upper layer contained stable $\mathrm{Li}_{2} \mathrm{~S}_{2} \mathrm{O}_{3}$ and $\mathrm{Li}_{\mathrm{S}} \mathrm{O}_{4}$ compounds.

No data related to the toxicity of long-chain PSs were found in literature.

According to [338], in contact with water, $\mathrm{Li}_{2} \mathrm{~S}$ is able to release flammable gas. It is toxic after swallowing. It induces severe skin burns and eye damage. Some hazard statements assigned to $\mathrm{Li}_{2} \mathrm{~S}$ are shown in Table 12.

Phosphorus Pentasulfide

Another additive, phosphorus pentasulfide $\left(\mathrm{P}_{2} \mathrm{~S}_{5}\right)$ was reported in [339].

Table 12. Hazard statements of $\mathrm{LiNO}_{3}, \mathrm{Li}_{2} \mathrm{~S}$, and $\mathrm{P}_{2} \mathrm{~S}_{5}$.

\begin{tabular}{ccc}
\hline Material & Class of EC 1272/2008 & References \\
\hline $\mathrm{LiNO}_{3}$ & $\mathrm{H} 272, \mathrm{H} 302, \mathrm{H} 319$ & {$[334]$} \\
$\mathrm{Li}_{2} \mathrm{~S}$ & $\mathrm{H} 261, \mathrm{H} 301, \mathrm{H} 314$ & {$[338]$} \\
$\mathrm{P}_{2} \mathrm{~S}_{5}$ & $\mathrm{H} 228, \mathrm{H} 260, \mathrm{H} 302, \mathrm{H} 332, \mathrm{H} 400$ & {$[340]$} \\
\hline
\end{tabular}

According to [340], $\mathrm{P}_{2} \mathrm{~S}_{5}$ is a flammable solid. In contact with water it releases flammable gases igniting spontaneously. It is harmful after swallowing or inhalation. It is also very toxic to aquatic life. Some hazard statements assigned to $\mathrm{P}_{2} \mathrm{~S}_{5}$ are shown in Table 12.

\subsection{Anode Materials}

Metallic lithium is commonly utilized as an anode material for Li-S cells, but because of its instability in organic electrolytes, generates problems related to the safety of cells. According to [52], a Li anode needs to be protected against the side deposition and corrosion of PSs.

The electrolyte additives, including $\mathrm{LiNO}_{3}$ [341-343] and $\mathrm{InI}_{3}$ [344], and anodic protection interlayers, such as PEDOT-co-PEG [345] and $\mathrm{Li}_{3} \mathrm{~N}$ [346] limited the unwanted lithium dendrite development.

According to [347], indium (III) iodide may induce serious irritation of eyes, an allergic skin reaction, or irritation of respiratory tract. It is also able to damage fertility or the unborn child.

No data related to the toxicology of PEDOT-co-PEG were found in literature. However, according to [348], poly(3,4-ethylenedioxythiophene)-blockpoly (ethylene glycol) is a flammable liquid and vapor. It is harmful after swallowing and suspected of causing cancer.

As reported in [349], in contact with water, $\mathrm{Li}_{3} \mathrm{~N}$ releases flammable gases igniting spontaneously. It induces severe skin burns and serious eye damage.

Some hazard statements assigned to indium (III) iodide, poly(3,4-ethylenedioxythiophene)-blockpoly (ethylene glycol), and to $\mathrm{Li}_{3} \mathrm{~N}$ are presented in Table 13. 
Table 13. Hazard statements of indium (III) iodide, poly(3,4-ethylenedioxythiophene)-blockpoly (ethylene glycol), and $\mathrm{Li}_{3} \mathrm{~N}$.

\begin{tabular}{ccc}
\hline Material & Class of EC 1272/2008 & References \\
\hline Indium (III) iodide & H314, H317, H334, H361 & {$[347]$} \\
poly(3,4-ethylenedioxythiophene)-blockpoly (ethylene glycol) & H302, H226, H351 & {$[348]$} \\
$\mathrm{Li}_{3} \mathrm{~N}$ & $\mathrm{H} 314, \mathrm{H} 318, \mathrm{H} 260$ & {$[349]$} \\
\hline
\end{tabular}

H334-May cause allergy or asthma symptoms or breathing difficulties if inhaled.

\subsubsection{Lithium Anode}

The lithium anode degrades during cyclic operation, creating dendrites decreasing the cyclability performance, and creating safety problems for renewable batteries [350-353].

These problems can be solved by adding $\mathrm{LiNO}_{3}, \mathrm{PS}$, or $\mathrm{P}_{2} \mathrm{~S}_{5}$ to electrolytes.

Changing the amounts of $\mathrm{PSs}_{\text {and }} \mathrm{LiNO}_{3}$ in the electrolyte, Li et al. [354] obtained a stable and even SEI built on the Li surface. That greatly limited the side reactions and dendrite development.

Yan et al. [355] used a $0.02 \mathrm{M} \mathrm{Li}_{2} \mathrm{~S}_{5}\left(0.10 \mathrm{M}_{\text {sulfur }}\right)-5.0 \mathrm{wt} \% \mathrm{LiNO}_{3}$ based ether electrolyte to increase the cycling stability of the Li metallic anode.

No data related to the toxicity of $0.02 \mathrm{M} \mathrm{Li}_{2} \mathrm{~S}_{5}\left(0.10 \mathrm{M}_{\text {sulfur }}\right)-5.0 \mathrm{wt} \% \mathrm{LiNO}_{3}$ were found in literature.

Protected anodes from metallic Li can limit the corrosion problems of the anodes in Li-S cells.

According to [356], several hosts for Li metal anode can limit the Li dendrite development, stabilizing the Li metal/electrolyte interface, diminishing volume change, and enhancing the electrode efficiency. Such hosts are the following: Carbon nanotubes (CNTs), graphene, graphene-CNT hybrid, $C$ nanofiber, porous $C$, graphite particles, graphite microtubes, TiC-C hybrid, 3D Cu current, $\mathrm{Cu}-\mathrm{Ni}$ hybrid, metal foam, $\mathrm{AlF}_{3}$ framework, $\mathrm{Li}$ alloys, and glass fibers. Such matrixes control the nucleation and growth of $\mathrm{Li}$ ion by the lithiophilic sites and limit the Li dendrite development by the enhanced surface areas. The above-mentioned hosts are merely matrixes without Li in them. The most promising are Li metal anode half cells or full cells with the routine Li-containing oxide or phosphate counter electrodes.

No data directly related to the toxicity of graphene-CNT hybrid, $\mathrm{C}$ nanofiber, porous $\mathrm{C}$, graphite microtubes, TiC-C hybrid, 3D $\mathrm{Cu}$ current, $\mathrm{Cu}-\mathrm{Ni}$ hybrid, metal foam, $\mathrm{AlF}_{3}$ framework, $\mathrm{Li}$ alloys, and glass fibers used as host anode material were found in literature.

According to [357], carbon nanotubes cause serious eye irritation and may induce respiratory irritation.

As reported in [358], graphite powder may induce irritation of eyes, skin, and respiratory tract. It may induce gastrointestinal irritation with nausea, vomiting, and diarrhea.

According to [359], TiC is a flammable solid. It is able to induce irritation of eyes and skin. The irritation can occur after ingestion or inhalation. It is of low aquatic toxicity.

As reported in [360], granular copper is a combustible dust. It is fatal if swallowed or inhaled. It may induce damage to the digestive system, hematopoietic system, kidneys, nose, respiratory system, and skin via prolonged or repeated endangering if inhaled. It induces serious irritation of eyes. It is able to induce an allergic skin reaction and genetic defect. It is also very toxic to aquatic life.

According to [361], copper nickel is a flammable solid. It may induce an allergic skin reaction and respiratory irritation. It induces serious irritation of eyes and damage to organs via prolonged or repeated endangering. It is suspected of causing cancer. It is also of the high aquatic toxicity.

Additionally, as reported in [362], nickel is a flammable solid. It may induce an allergic skin reaction. It is suspected of causing cancer. It induces damage to organs via prolonged or repeated endangering via inhalation. It is also very toxic to aquatic life with long lasting impacts.

According to [363], $\mathrm{AlF}_{3}$ is fatal after swallowing. It induces severe skin burns and damage of eyes.

Table 14 presented some hazard statements assigned to carbon nanotube, $\mathrm{TiC}$, granular copper, $\mathrm{CuNi}, \mathrm{Ni}$, and $\mathrm{AlF}_{3}$. 
Table 14. Hazard statements of carbon nanotube, $\mathrm{TiC}$, granular copper, $\mathrm{CuNi}, \mathrm{Ni}$, and $\mathrm{AlF}_{3}$.

\begin{tabular}{ccc}
\hline Material & Class of EC 1272/2008 & References \\
\hline carbon nanotube & $\mathrm{H} 319, \mathrm{H} 335$ & {$[357]$} \\
$\mathrm{TiC}$ & $\mathrm{H} 228$ & {$[359]$} \\
copper granular & $\mathrm{H} 300, \mathrm{H} 330, \mathrm{H} 319, \mathrm{H} 317, \mathrm{H} 340, \mathrm{H} 373, \mathrm{H} 400$ & {$[360]$} \\
$\mathrm{CuNi}$ & $\mathrm{H} 228, \mathrm{H} 317, \mathrm{H} 319, \mathrm{H} 335, \mathrm{H} 351, \mathrm{H} 372$ & {$[361]$} \\
$\mathrm{Ni}$ & $\mathrm{H} 228, \mathrm{H} 317, \mathrm{H} 351, \mathrm{H} 372, \mathrm{H} 410$ & {$[359]$} \\
$\mathrm{AlF}_{3}$ & $\mathrm{H} 300, \mathrm{H} 314$ & {$[360]$} \\
\hline
\end{tabular}

H330-Fatal if inhaled; H340-May cause genetic defects.

From the high temperature alloying reaction of $\mathrm{Li}$ and $\mathrm{B}$, Cheng et al. [364] derived a 3D fibrous $\mathrm{Li}_{7} \mathrm{~B}_{6}$ matrix used as an inert host for elemental $\mathrm{Li}$.

A next composite Li metal anode was received by a melting process [365-368].

Utilizing the LiF surface passivation on a 3D layered Li-rGO electrode a composite Li metallic anode was obtained and rendered $\mathrm{Li}-\mathrm{S}$ cells [369].

No data related to toxicity of 3D fibrous $\mathrm{Li}_{7} \mathrm{~B}_{6}, \mathrm{LiF}$, and 3D layered Li-rGO were found in literature.

\subsubsection{Protected Anodes from Metallic Lithium}

A stable thin protective layer can be performed on the Li anode using the plasma polymerization, which aids the corrosion of the anode [370].

The $\mathrm{Li}_{2} \mathrm{CO}_{3}$ protective layer can be formed on the anode by exposing the carbon dioxide electrode [371,372].

According to [373], $\mathrm{Li}_{2} \mathrm{CO}_{3}$ is harmful after swallowing. It induces skin irritation, serious eye irritation, and eye damage. It may induce irritation of respiratory tract and damage fertility or the unborn child. It also induces damage to organs through prolonged or repeated endangering.

The reaction between $\mathrm{Li}$ and DOL also creates a protective layer on the lithium surface, which increases the durability of the $\mathrm{Li}$ anode [183].

No data related to the toxicity of such protective layer were found in literature.

The lifetime of Li-S cell can be prolonged using the LiAl alloy layer on the lithium surface [374] or $\mathrm{LiNO}_{3}$ and organic nitrate additives in liquid electrolytes [375].

No data related to the toxicity of LiAl were found in literature.

$\mathrm{Li}$ et al. [354] obtained thicker and less severe morphology of Li fibers deposited in the $\mathrm{LiNO}_{3}$ electrolyte in comparison to that obtained at the lack of $\mathrm{LiNO}_{3}$. They found that $\mathrm{LiNO}_{3}$ alone cannot limit the growth of dendrites. Moreover, a density of the arising Li particles decreased with the addition of both $\mathrm{Li}_{2} \mathrm{~S}_{8}$ and $\mathrm{LiNO}_{3}$ to the electrolyte.

According to [356], surface coating can provide a protective layer on the Li metallic anode. Such coating materials included $\mathrm{Al}_{2} \mathrm{O}_{3}$, carbon, some polymers, and alloys. The $\mathrm{Li}-\mathrm{S}$ cell with a thin $\mathrm{Li}-\mathrm{Al}$ alloy coating layer on the $\mathrm{Li}$ anode has a higher cyclability than one with pure $\mathrm{Li}$ anode.

Three pieces of information related to the toxicity of $\mathrm{Al}_{2} \mathrm{O}_{3}$ were found in literature.

According to [376], $\mathrm{Al}_{2} \mathrm{O}_{3}$ is harmful after inhalation.

As reported in [377], aluminas are nuisance dusts but their role in fibrogenic lung disease is still unclear. Serious aluminium levels occurred in the lungs of subjects in the long-term exposed to alumina dust. Animal experiments showed that prolonged inhalation of alumina increased the Al concentration in the brain. $\mathrm{An} \mathrm{Al}, \mathrm{Al}_{2} \mathrm{O}_{3}$, and aluminium hydroxide $\mathrm{Al}(\mathrm{OH})_{3}$ induced no pulmonary impacts. In some of aluminium smelter employees, either minimal or absent fibronodular disease and no excess mortality accompanied by pneumoconiosis were observed. Some researches pointed that alumina can generate aluminosis while others proposed the utilization of powdered alumina by inhalation as a therapeutic method for silicosis. The chronic endangering to serious concentrations of alumina can induce a light pulmonary fibrogenic reaction and the existence of small opacities on the chest X-ray. A fibrosis can occur after the prolonged endangering to alumina during the production of abrasives. 
Independently from endangering to other pneumotoxicants, massive inhalation of aluminium or alumina can favor the development of interstitial fibrosis. An asthmatic form syndrome can occur among potroom workers endangered to volatile fluorides. A respiratory obstructive syndrome can occur among employees of the manufacture of aluminium fluoride.

Sadiq et al. [378] found the growth inhibitory impact of $\mathrm{Al}_{2} \mathrm{O}_{3}$ NPs on microalgae. Bulk alumina also exhibited toxicity though to a lesser extent. A chlorophyll content decreased in the treated cells compared to the untreated ones, more intensively in the case of nanoparticles. Interaction of the $\mathrm{Al}_{2} \mathrm{O}_{3}$ NPs with the cell surface can occur.

Cha et al. [379] used 2D molybdenum disulfide $\left(\mathrm{MoS}_{2}\right)$ as a protective layer for Li-metal anodes to increase the efficiency of Li-S cells. The utilization of $\mathrm{MoS}_{2}$ allowed obtaining a stable Li electrodeposition and limiting dendrite nucleation sites.

Chen et al. [380] reported that cytotoxicity and patch tests confirmed the weak toxicity of molybdenum disulfide (MoS2) atomically thin film.

Table 15 presented some hazard statements assigned to $\mathrm{Li}_{2} \mathrm{CO}_{3}$ and $\mathrm{Al}_{2} \mathrm{O}_{3}$.

Table 15. Hazard statements of $\mathrm{Li}_{2} \mathrm{CO}_{3}$ and $\mathrm{Al}_{2} \mathrm{O}_{3}$.

\begin{tabular}{ccc}
\hline Material & Class of EC 1272/2008 & References \\
\hline $\mathrm{Li}_{2} \mathrm{CO}_{3}$ & $\mathrm{H} 302, \mathrm{H} 315, \mathrm{H} 318, \mathrm{H} 319, \mathrm{H} 335, \mathrm{H} 360, \mathrm{H} 372$ & {$[373]$} \\
$\mathrm{Al}_{2} \mathrm{O}_{3}$ & $\mathrm{H} 332$ & {$[376]$} \\
\hline
\end{tabular}

\subsection{Separators}

Separator is a key element in the Li-S cell [381-383].

Yao et al. [378] elaborated the cell with the polypropylene (PP) separator and the conducting cover of different materials, such as MWCNTs or a Super P.

Microporous polyolefin membranes are the usually used separators for lithium cells.

In the beginning, a polymer separator was modified by covering with a Super-P carbon layer on one side [384].

In [385], a Nafion layer was introduced on a PP/PE/PP separator.

No data directly related to the toxicity of microporous polyolefin membranes and $\mathrm{PP} / \mathrm{PE} / \mathrm{PP}$ separator were found in literature.

Hwang et al. [386] described that the accumulation of microplastic particles in humans can induce cytotoxicity, hypersensitivity, unwanted immune response, and acute response such as hemolysis. They studied the cellular responses of secondary polypropylene microplastics (PP particles) in various conditions and sizes to normal cells, immune ones, blood ones, and murine immune ones. The analyzed PP particles exhibited a weak cytotoxicity impact in size and concentration way. They can induce pro-inflammatory cytokines such as IL-6, TNF alpha, and histamine causing a local immune response.

Analyzing the multi-walled carbon nanotubes (MWCNTs) of comparable length, Allegri et al. [387] observed that for the size above $40 \mathrm{~nm}$, there was no detrimental impacts on the cell viability of macrophages. The mild cytotoxicity occurred for the size between 15 and $40 \mathrm{~nm}$, with a mitigating impact of functionalization. Substantial mitigation of the changes induced by pristine MWCNT occurred both with carboxyl- and amino-functionalized MWCNT. It meant that the impact was affected not only by a negative or positive surface charge. Instead, either functionalized preparation strongly tended to agglomeration strictly affected by the presence of proteins. Either carboxyl- or amino-functionalized MWCNT adsorbed more serum proteins than pristine counterparts. The formation of larger agglomerates, affected by various protein coronae, mitigated the biological impacts of functionalized MWCNT in protein-rich biological media.

Two pieces of information related to the toxicity of Super P carbon were found in literature.

Chaudhuri et al. [388] considered a carbon black (Super P) as a poorly soluble, weak toxicity (PSLT) particle. However, carbon black may be directly genotoxic, and is also able to induce reproductive 
toxicity. The carbon black cannot directly interact with DNA. Under its high concentrations, carbon black induces inflammation and oxidative stress in the lung leading to mutations. Carbon black can induce non-specific inflammatory effects under serious exposure doses. An oral gavage investigation reported no adverse reproductive or developmental impacts at the highest dose tested. The carbon black is not a direct genotoxicant or reproductive toxicant.

As reported in [389], Super P carbon may induce irritation of eyes and skin.

According to [390], polyolefin particulates are able to scratch eye surfaces and induce mechanical irritation.

According to [341], separators comprise anodic alumina with a thickness of 60 microns and exhibit a well-fitting nanopores throughout their thickness.

Two pieces of information related to the toxicity of aluminium were found in literature.

According to [391], the aluminium was studied for its potential to induce toxic impacts in humans exposed via inhalation, oral, or dermal contact. The lungs and nervous system were the most sensitive targets of toxicity following inhalation endangering.

Wang et al. [392] conducted the in vitro nanotoxicity investigation using anodic alumina nanotubes (AANTs). Cytotoxicity studies were carried out with RAW 264.7 mouse macrophage cells and MDA-MB 231-TXSA human breast cancer cells. The obtained toxicity was affected by the cell-type and AANTs dose, length of time, and the AR window of AANTs. Long AANTs triggered enhanced cell death, morphological changes, tumor necrosis factor a (TNF-a) release, lysosomal membrane permeabilization (LMP), and endoplasmic reticulum (ER) stress than short AANTs. The toxic AR window of AANTs was equal to 7.8, which was shorter than that of other high aspect ratio (HAR) nanomaterials.

Liu et al. [52] reported the separator coated by a thin layer of $C$, polymer or oxide on the cathode side or grafted by suitable functional groups. Super-P, graphene, mesoporous $\mathrm{C}$, multi walled carbon nanotubes (MWCNT)@PEG, Nafion, polydopamine, glassy fiber paper, black P, sulfonated acetylene black, and carboxyl functional groups can decorate commercial separators and increase the immobilization function.

Zhou et al. [90] elaborated a graphene secured separator used to create a sandwich-structured S cathode with the graphene-separator bilayer.

Chen et al. [393] studied the toxicity of mesoporous carbon nanomaterials MCNs in the lung under the scenario of moderate environmental endangering. At a weak concentration MCNs induced biophysical inhibition of natural pulmonary surfactant and decreased the viability of J774A.1 macrophages and lung epithelial A549 cells. Incubating with nature pulmonary surfactant decreased the cytotoxicity of MCNs. Such nanomaterials activated macrophages in vitro, and stimulated lung inflammation in mice after inhalation endangering, associated with lung fibrosis. The size of MCNs affected cytotoxicity and their pro-inflammatory potential. The larger size caused more pronounced cytotoxic and pro-inflammatory impacts than the smaller one.

Zhao et al. [394] reported that polydopamine (PDA) nanoparticles had a strong anti-inflammation therapeutic impact on acute inflammation-induced injury. PDA with enriched phenol groups eliminated reactive oxygen species (ROS) generated during inflammations.

Hesterberg et al. [395] determined that the chronic biological impacts in Fisher 344 rats inhaled the respirable fractions of fibrous glass (FG). FG endangering was linked with a nonspecific inflammation in the lungs that stabilized during long term endangering. These cellular changes were convertible and congruous to impacts caused by inhalation of inert dust. No lung fibrosis occurred in the FG-exposed rats. Further, FG endangering caused no mesotheliomas and no enhancing in lung tumor incidence. The respirable fibrous glass exhibited no insignificant hazard for fibrotic or neoplastic lung disease in humans.

Sun et al. [396] studied in vitro and in vivo toxicity of black phosphorus BP nanosheets. The BP nanosheets decreased the viability of human bronchial epithelial cells in a time- and dose-dependent manner. They interfered with the mitochondrial membrane potential increasing the intracellular ROS. These responses further activated the caspase- 3 and ultimately dictated cells to undergo apoptosis. 
The single injection of BP nanosheets caused no toxicity to mice in a short period of time, whereas multiple injections of BP nanosheets disrupted the liver and renal function of mice. Such functions returned to normal after a recovery period.

Kalgutkar and Scott [397] reported that a carboxylic acid-containing NSAIDs were withdrawn from clinical use due to their induction of hepatotoxicity. Acylglucuronides and acyl CoA thioesters caused toxicity associated with this functional group. Reactions of such metabolites with critical proteins can disturb the ion cellular functionality or may induce an immune response, causing adverse impacts that can be fatal.

Yu et al. [398] elaborated the PP separator grafted by facile carboxyl functional groups.

Zhao et al. [399] presented that the a G-LTO/PP separator coated with a dense hybrid system comprised orientation adjusted graphene layers and evenly embedded $\mathrm{Li}_{4} \mathrm{Ti}_{5} \mathrm{O}_{12} \mathrm{NPs}$.

No data directly related to the toxicity of grafting facile carboxyl functional groups and a G-LTO/PP were found in literature.

Two pieces of information related to the toxicity of $\mathrm{Li}_{4} \mathrm{Ti}_{5} \mathrm{O}_{12}$ were found in literature.

Kim D. and Kim J. [400] stated that the non-toxic $\mathrm{Li}_{4} \mathrm{Ti}_{5} \mathrm{O}_{12}$ can be utilized as an anode for lithium ion cell.

Jo et al. [401] reported that the in vitro cytotoxicity test of phosphidated- $\mathrm{Li}_{4} \mathrm{Ti}_{5} \mathrm{O}_{12}$ proved a high cell viability, indicating that the phosphidation is helpful in resolving the toxicity problem of NPs.

According to the review made by $\mathrm{Ou}$ et al. [402], the toxicity of graphene-family nanomaterials (GFNs) in animals or cell models was affected by the lateral size, surface structure, functionalization, charge, impurities, aggregations, and corona effect. The GFN toxicity is manifested through physical destruction, oxidative stress, DNA damage, inflammatory response, apoptosis, autophagy, and necrosis. In the mentioned mechanisms, (toll-like receptors-) TLR-, transforming growth factor $\beta$ - (TGF- $\beta$-), and tumor necrosis factor-alpha (TNF- $\alpha$ ) dependent-pathways created the signaling pathway network strongly affected by oxidative stress.

Sironval et al. [403] reported that LTO particles caused an acute inflammation and long persistence in mice lungs after administration but no inflammation or fibrosis occurred. The low toxicity of LTO resulted from low-toxic $\mathrm{TiO}_{2}$ content therein. $\mathrm{TiO}_{2}$ induced low acute inflammation and no fibrosis when inhaled.

Zhuang et al. [404] elaborated a ternary-layered separator comprising a macroporous PP matrix layer, GO barrier, and Nafion retarding layer applicable to Li-S batteries.

Zhuang et al. [405] elaborated a porous PAN/GO nanofiber membrane separator.

Two pieces of information related to the toxicity of PAN/GO were found in literature.

Sharma et al. [406] elaborated graphene-oxide-based hydrophobic PAN/GO nanofibers. The graphene oxide nanofibers can photo-catalytically degrade the carcinogenic dyes from industrial water.

Lee et al. [407] elaborated the polyacrylonitrile-graphene oxide (PAN-GO) composite nanofibers utilized during formation of membrane sheets. Such composite membranes can be used in the purification of water. The suitable integration of GO into the PAN nanofibers provide the high protein rejection rate and water flux during the filtration process.

Bai et al. [408] presented a separator based on a metal-organic framework (MOF)/GO composite film. No data directly related to the toxicity of (MOF)/GO composite were found in literature.

Filippousi et al. [409] found that both extracellular and intracellular homeostasis depends on the occurrence of metal atoms in the MOFs coordinated bonds structure. The degree of the homeostatic changes is strongly affected by the material's composition and structure.

During tests on human epithelial cells from fetal cervical carcinoma (HeLa) and murine macrophage cell line (J774), Tamames-Tabar et al. [410] evaluated the toxicity of fourteen porous metal-organic frameworks (MOFs) with various constitutions (Fe, Zn, and Zr carboxylates or imidazolates) and arrangements. The MOF NPs showed weak cytotoxicity. The less toxic were the Fe carboxylate NPs and the more toxic were the $\mathrm{Zn}$ imidazolate ones. The cytotoxicity values, higher in J774 cells than 
in HeLa cells, were strongly affected by their constitution and cell internalization capacity. The cell uptake of Fe-MOF-NPs showed faster kinetics of cell penetration within J774 than within HeLa cells.

Ruyra et al. [411] evaluated the toxicity of sixteen uncovered MOFs in exposed zebrafish embryos. They found that the toxicity was affected by the material setup and the individual-related leaching of metal ions.

Ren et al. [412] reported that the toxicity of IRMOF-3, a rigid cubic zinc-based MOF was affected by time and strength during tests on rat pheochromocytoma cells.

Grall et al. [413] reported that mesoporous MOFs based on $\mathrm{Fe}$, $\mathrm{Al}$, or $\mathrm{Cr}$ exhibited low toxicity during tests on hepatic cells (HepG2 and Hep3B) and lung cells (A549 and Calu-3).

Wagner et al. [414] tested in a model-way the toxicity of a MIL-160, a microporous hydrophilic aluminium-based MOF with a five-membered ring and an oxygen heteroatom, and ZIF-8, a hydrophobic framework of zeolitic imidazolate on the human bronchial epithelial (BEAS-2B) cells.

Chang et al. [415] reported a separator modulated by the single-wall carbon nanotubes (SWCNTs).

In animal studies reviewed by Kobayashi et al. [416], CNTs could cause inflammation, fibrosis, and lung cancer after long-term inhalation and gene damage in the lung. CNTs were also highly bio-persistent. Mice administered with MWCNTs could exhibit fetal malformations, fetal loss, changed behavior for offsprings and the first litter delayed. Single-walled carbon nanotubes (SWCNTs) could cause embryolethal and teratogenic changes in mice. Tubes could cause death and growth delay in chicken embryos. The carcinogenicity of CNTs could be lower if the fibers are shorter.

Kumar et al. [417] reported that Celgard separators are often used in the Li-ion batteries.

Weng et al. [418] discussed a Celgard separator covered with lithiated Nafion/polyvinylidene fluoride (PVDF), i.e., PVDF-Nafion covered Celgard (PNC) developed for blocking PS ions. They studied nonaqueous lithium/organosulfides battery (LOB) using such PNC separator.

Deepa et al. [419] reported the utilization of a porous organic polymer-coated Celgard 2320 (POP-CG) separator in the Li-S cell.

One piece of information related to the toxicity of the Celgard polypropylene-polyethyerlenepolypropylene separator was found in literature.

According to [420], no specific danger relates to the normal use of the product. However, the plastic film left on the ground is slippery and during converting of film rolls electrostatic discharges can occur. When exposed to flames, polyethene film burns, giving off harmful fumes. Molten droplets of polymer can be produced, igniting the adjacent flammable and/or combustible materials. By direct ignition the product burns with flames, developing $\mathrm{H}_{2} \mathrm{O}, \mathrm{CO}_{2}$, and $\mathrm{CO}$. The fire products are irritant and toxic. In the growing fires, hydrocarbons and aldehydes (acetaldehyde, crotonaldehyde) may be formed.

\section{Materials and Methods}

Using 'logical' database searches, literature from electronic databases such as 'ISI Web of Science', 'Scopus', and 'Google Scholar' was obtained. The period studied in the literature on lithium-sulfur cells ranged from 1962 to 2020. Only articles published in English are included, as they are widely available to readers around the world.

\section{Summary}

The review of materials used for components of different Li-S cells and the toxicity and hazards of these materials has been done. The review showed lots of kind of materials with different levels of toxicity utilized for manufacturing of this new class of cells. Some materials, for example, vanadium pentoxide is of low toxicity and some others, for example, DEGDME and TEGDME ethers are of the high toxicity. Unstudied toxicity may relate to the final form of the Li-S cell component or, more rarely, to the raw material used to manufacture the component or material particles during recycling of the cell component. A lot of materials, for example, $\mathrm{LiClO}_{4}$ have assigned different hazard statements. For some of materials, for example, $\mathrm{Al}_{2} \mathrm{O}_{3}$, no hazard statements assigned to it were found in literature, although such materials are toxic. No data related to the toxicity of some materials, for example, 
dimethyleneglycol dimethyl ether were found in literature. This pointed to the necessity of further studies on their toxicity and legal actions to assign appropriate hazard statements. Suggestions can be made with caution regarding the least toxic materials used for the main components of Li-S cell. These suggestions are shown in Table 16.

Table 16. Suggestions for the least toxic materials used for the main components of Li-S cell.

\begin{tabular}{|c|c|c|}
\hline Material & $\begin{array}{c}\text { Li-S Cell } \\
\text { Component }\end{array}$ & Comments \\
\hline Gelatin & Binder & Practically non-toxic \\
\hline perovskite type $\mathrm{La}_{(2 / 3) \times} \mathrm{Li}_{3 x} \mathrm{TiO}_{3}(\mathrm{LLT})$ & Electrolyte & Ionic conducting solid materials are the least electrolytes \\
\hline Lithium protected by DOL layer & Anode & Protecting layer limits the toxicity of pure lithium \\
\hline Carbon + Sulfur & Cathode & $\begin{array}{l}\mathrm{C} \text { is much lower toxic than } \mathrm{S} \text {. The content of } \mathrm{S} \text { should be } \\
\text { limited to the necessary minimum. }\end{array}$ \\
\hline
\end{tabular}

Funding: This research received no external funding.

Conflicts of Interest: The author declares no conflict of interest.

\section{References}

1. De Lorenzo, G.; Andaloro, L.; Sergi, F.; Napoli, G.; Ferraro, M.; Antonucci, V. Numerical simulation model for the preliminary design of hybrid electric city bus power train with polymer electrolyte fuel cell. Int. J. Hydrog. Energy 2014, 39, 12934-12947. [CrossRef]

2. De Luca, D.; Fragiacomo, P.; De Lorenzo, G.; Czarnetzki, W.T.; Schneider, W. Strategies for Dimensioning Two-Wheeled Fuel Cell Hybrid Electric Vehicles Using Numerical Analysis Software. Fuel Cells 2016, 16, 628-639. [CrossRef]

3. Fragiacomo, P.; Astorino, E.; Chippari, G.; De Lorenzo, G.; Czarnetzki, W.T.; Schneider, W. Dynamic modeling of a hybrid electric system based on an anion exchange membrane fuel cell. Cogent. Eng. 2017, 4, 1357891. [CrossRef]

4. Bruce, P.G.; Freunberger, S.A.; Hardwick, L.J.; Tarascon, J.M. Li-O 2 and Li-S batteries with high energy storage. Nat. Mater. 2012, 11, 19-29. [CrossRef] [PubMed]

5. Sun, J.; Li, J.; Zhou, T.; Yang, K.; Wei, S.; Tang, N.; Dang, N.; Li, H.; Qiu, X.; Chen, L. Toxicity, a serious concern of thermal runaway from commercial Li-ion battery. Nano Energy 2016, 27, 313-319. [CrossRef]

6. Park, Y.J.; Kim, M.K.; Kim, H.S.; Lee, B.M. Risk assessment of lithium-ion battery explosion: Chemical leakages. J. Toxicol. Environ. Health Part B 2018, 21, 370-381. [CrossRef]

7. Manthiram, A.; Fu, Y.Z.; Chung, S.H.; Zu, C.X.; Su, Y.S. Rechargeable lithium-sulfur batteries. Chem Rev. 2014, 114, 11751-11787. [CrossRef]

8. Son, Y.; Lee, J.S.; Son, Y.; Jang, J.H.; Cho, J. Recent advances in lithium sulfide cathode materials and their use in lithium sulfur batteries. Adv. Energy Mater. 2015, 5, 1500110. [CrossRef]

9. Pang, Q.; Liang, X.; Kwok, C.Y.; Nazar, L.F. Advances in lithium-sulfur batteries based on multifunctional cathodes and electrolytes. Nat. Energy 2016, 1, 16132. [CrossRef]

10. Deng, Y.; Li, J.; Li, T.; Gao, X.; Yuan, C. Life cycle assessment of lithium sulfur battery for electric vehicles. J. Power Sources 2017, 343, 284-295. [CrossRef]

11. Mikhaylik, Y.; Kovalev, I.; Schock, R.; Kumaresan, K.; Xu, J.; Affinito, J. High energy rechargeable Li-S cells for EV application. status, remaining problems and solutions. ECS Trans. 2010, 25, 23-34. [CrossRef]

12. Herbert, D.; Ulam, J. Electric dry cells and storage batteries. U.S. Patent 3,043,896, 10 July 1962.

13. Rao, M.L.B. Organic electrolyte cells. U.S. Patent 3,413,154, 26 November 1968.

14. Chem-Supply PTY Ltd. Sulfur. CAS No.: 7704-34-9. Safety Data Sheet. (ABN 19008264211). 2014. Available online: https://www.chemsupply.com.au/documents/ST0061CH71.pdf (accessed on 22 May 2020).

15. Sigma-Aldrich. Sulfur. CAS No.: 7704-34-9. Material Safety Data Sheet, version 3.4. 2012. Available online: www.sigma-aldrich.com (accessed on 20 May 2020).

16. Ji, X.; Nazar, L.F. Advances in Li-S batteries. J. Mater. Chem. 2010, 20, 9821. [CrossRef]

17. Barghamadi, M.; Kapoor, A.; Wen, C. A review on Li-S batteries as a high efficiency rechargeable lithium battery. J. Electrochem. Soc. 2013, 160, A1256-A1263. [CrossRef] 
18. Bresser, D.; Passerini, S.; Scrosati, B. Recent progress and remaining challenges in sulfur-based lithium secondary batteries-A review. Chem. Commun. 2013, 49, 10545-10562. [CrossRef]

19. Evers, S.; Nazar, L.F. New approaches for high energy density lithium-sulfur battery cathodes. ACC Chem. Res. 2013, 46, 1135-1143. [CrossRef]

20. Manthiram, A.; Fu, Y.; Su, Y.S. Challenges and prospects of lithium-sulfur batteries. ACC Chem. Res. 2013, 46, 1125-1134. [CrossRef]

21. Song, M.K.; Cairns, E.J.; Zhang, Y. Lithium/sulfur batteries with high specific energy: Old challenges and new opportunities. Nanoscale 2013, 5, 2186-2204. [CrossRef]

22. Yin, Y.X.; Xin, S.; Guo, Y.G.; Wan, L.J. Lithium-sulfur batteries: Electrochemistry, materials, and prospects. Angew. Chem. Int. Ed. Engl. 2013, 52, 13186-13200. [CrossRef]

23. Chen, L.; Shaw, L.L. Recent advances in lithium-sulfur batteries. J. Power Sources 2014, 267, 770-783. [CrossRef]

24. Xu, G.Y.; Ding, B.; Pan, J.; Nie, P.; Shen, L.F.; Zhang, X.G. High performance lithium-sulfur batteries: Advances and challenges. J. Mater. Chem. A 2014, 2, 12662-12676. [CrossRef]

25. Dong, C.; Gao, W.; Jin, B.; Jiang, Q. Advances in Cathode Materials for High-Performance Lithium-Sulfur Batteries. iScience 2018, 6, 151-198. [CrossRef] [PubMed]

26. Paul Scherrer Institut. A new generation of lithium batteries is approaching industrial implementation. Our Research/Current topics from our research/Lithium-sulfur battery, 6 March 2013. Available online: https://www.psi.ch/en/media/our-research/lithium-sulfur-battery (accessed on 20 May 2020).

27. Benveniste, G.; Rallo, H.; Canals Casals, L.; Merino, A.; Amante, B. Comparison of the state of Lithium-Sulphur and lithium-ion batteries applied to electromobility. J. Environ. Manag. 2018, 226, 1-12. [CrossRef] [PubMed]

28. Liu, Z.; Fu, W.; Liang, C. Chapter 24-Lithium-Sulfur Batteries. In Handbook of Battery Materials, 2nd ed.; Daniel, C., Besenhard, J.O., Eds.; Wiley-VCH Verlag GmbH \& Co KGaA: Weinheim, Germany, 2011; pp. 811-840.

29. Yu, M.; Ma, J.; Song, H.; Wang, A.; Tian, F.; Wang, Y.; Qiu, H.; Wang, R. Atomic layer deposited TiO 2 on a nitrogen-doped graphene/sulfur electrode for high performance lithium-sulfur batteries. Energy Env. Sci. 2016, 9, 1495-1503. [CrossRef]

30. Wang, T.; Jiang, X. Toxicity Mechanism of Graphene Oxide and Nitrogen-doped Graphene Quantum Dots in RBCs Revealed by Surface-Enhanced Infrared Absorption Spectroscopy. Toxicol. Res. 2015, 4, 885-894. [CrossRef]

31. CamGraph Graphene Powder. Material Safety Data Sheet. Cambridge Nanosystems Ltd., 2019. Available online: https://cambridgenanosystems.com/wp-content/uploads/2015/05/CNS_CamGraph_MSDS_V1.0.pdf (accessed on 22 May 2020).

32. Conductive Graphene Sheets. CAS-No.: 7782-42-5. Safety Data Sheet. Graphene Supermarket, 2016. Available online: www.graphene-supermarket.com (accessed on 20 May 2020).

33. Giampiccolo, A.; Tobaldi, D.M.; Leonardi, S.G.; Murdoch, B.J.; Seabra, M.P.; Ansell, M.P.; Neri, G.; Ball, R.J. Sol gel graphene/ $/ \mathrm{TiO}_{2}$ nanoparticles for the photocatalytic-assisted sensing and abatement of $\mathrm{NO}_{2}$. Appl. Catal. B Environ. 2019, 243, 183-194. [CrossRef]

34. Landmann, M.; Rauls, E.; Schmidt, W.G. The electronic structure and optical response of rutile, anatase and brookite $\mathrm{TiO}_{2}$. J. Phys. Condens Matter. 2012, 24, 195503. [CrossRef]

35. Grande, F.; Tucci, P. Titanium Dioxide Nanoparticles: A Risk for Human Health? Mini Rev. Med. Chem 2016, 16, 762-769. [CrossRef]

36. LTS Research Laboratories Inc. Titanium Oxide. Safety Data Sheet. 2017. Available online: https: //www.ltschem.com/msds/TiO2.pdf (accessed on 22 May 2020).

37. Zhou, G.; Zhao, Y.; Zu, C.; Manthiram, A. Free-standing $\mathrm{TiO}_{2}$ nanowire-embedded graphene hybrid membrane for advanced Li/dissolved polysulfide batteries. Nano Energy 2015, 12, 240-249. [CrossRef]

38. Li, F.; Wang, G.; Wang, P.; Yang, J.; Zhang, K.; Liu, Y.; Lai, Y. High-performance lithium-sulfur batteries with a carbonized bacterial cellulose/TiO2 modified separator. J. Electroanal Chem. 2017, 788, 150. [CrossRef]

39. Dourado, F.; Gama, M.; Rodrigues, A.C. A Review on the toxicology and dietetic role of bacterial cellulose. Toxicol. Rep. 2017, 4, 543-553. [CrossRef]

40. Guo, Y.; Zhao, G.; Wu, N.; Zhang, Y.; Xiang, M.; Wang, B.; Liu, H.; Wu, H. Efficient synthesis of graphene nanoscrolls for fabricating sulfur-loaded cathode and flexible hybrid interlayer toward high-performance Li-S batteries. ACS Appl. Mater. Interfaces 2016, 8, 34185. [CrossRef] [PubMed] 
41. Lee, H.Y.; Goodenough, J.B. Supercapacitor behavior with KCl electrolyte. J. Solid State Chem. 1999, 144, 220-223. [CrossRef]

42. Lee, H.Y.; Manivannan, V.; Goodenough, J. Electrochemical capacitors with KCl electrolyte. Comptes Rendus Acad. Des. Sci. Ser. IIC Chem. 1999, 2, 565-577. [CrossRef]

43. Lee, T.H.; Pham, D.T.; Sahoo, R.; Seok, J.; Luu, T.H.T.; Lee, Y.H. High energy density and enhanced stability of asymmetric supercapacitors with mesoporous $\mathrm{MnO}_{2} @ \mathrm{CNT}$ and nanodot $\mathrm{MoO}_{3} @ \mathrm{CNT}$ free-standing films. Energy Storage Mater. 2018, 12, 223-231. [CrossRef]

44. Ji, L.; Lin, Z.; Alcoutlabi, M.; Zhang, X. Recent developments in nanostructured anode materials for rechargeable lithium-ion batteries. Energy Env. Sci. 2011, 4, 2682-2699. [CrossRef]

45. National Center for Biotechnology Information. PubChem Database. Manganese dioxide, $\mathrm{CID}=14801$. Available online: https://pubchem.ncbi.nlm.nih.gov/compound/Manganese-dioxide (accessed on 16 May 2020).

46. LTS Research Laboratories, Inc. Manganese oxide CAS No.: 1317-35-7. Safety Data Sheet. Available online: https://www.ltschem.com/msds/Mn3O4.pdf (accessed on 22 May 2020).

47. Liu, M.; Li, Q.; Qin, X.; Liang, G.; Han, W.; Zhou, D.; He, Y.B.; Li, B.; Kang, F. Suppressing self-discharge and shuttle effect of lithium-sulfur batteries with $\mathrm{V}_{2} \mathrm{O}_{5}$-decorated carbon nanofiber interlayer. Small 2017, 13, 1602539-1602545. [CrossRef]

48. Monash University. Carbon fibre composites. OHS information sheet. 2009. Available online: https://www.monash.edu/ohs/info-docs/safety-topics/chemical-management/carbon-fibre-compositesohs-information-sheet (accessed on 20 May 2020).

49. Whittingham, M.S. Ultimate limits to intercalation reactions for lithium batteries. Chem. Rev. 2014, 114, 11414-11440. [CrossRef]

50. EVRAZ Stratcor, Inc. Vanadium Pentoxide [V2O5]. Safety Data Sheet. 2015. Available online: www. evrazstratcor.com (accessed on 20 May 2020).

51. Peled, E.; Gorenshtein, A.; Segal, M.; Sternberg, Y. Rechargeable Lithium-Sulfur Battery. J. Power Sources 1989, 26, 269-271. [CrossRef]

52. Liu, M.; Qin, X.; He, Y.-B.; Li, B.; Kang, F. Recent innovative configurations in high-energy lithium-sulfur batteries. J. Mater. Chem. A 2017, 5, 5222-5234. [CrossRef]

53. Nole, D.A.; Moss, V. Battery employing lithium-sulphur electrodes with non-aqueous electrolyte. U.S. Patent 3,532,543, 6 October 1970.

54. Eichinger, G.; Besenhard, J.O. High energy density lithium cells: Part II. Cathodes and complete cells. J. Electroanal. Chem. Interfacial Electrochem. 1976, 72, 1-31. [CrossRef]

55. Rauh, R.D.; Abraham, K.M.; Pearson, G.F.; Surprenant, J.K.; Brummer, S.B. A Lithium/Dissolved Sulfur Battery with an Organic Electrolyte. J. Electrochem. Soc. 1979, 126, 523-527. [CrossRef]

56. National Center for Biotechnology Information. PubChem Database. Lithium Hexafluoroarsenate, CID=9837036. Available online: https://pubchem.ncbi.nlm.nih.gov/compound/Lithium-hexafluoroarsenate (accessed on 15 May 2020).

57. Marmorstein, D.; Yu, T.H.; Striebel, K.A.; McLarnon, F.R.; Hou, J.; Cairns, E.J. Electrochemical performance of lithium/sulfur cells with three different polymer electrolytes. J. Power Sources 2000, 89, 219-226. [CrossRef]

58. Jeon, B.H.; Yeon, J.H.; Kim, K.M.; Chung, I.J. Preparation and electrochemical properties of lithium-sulfur polymer batteries. J. Power Sources 2002, 109, 89-97. [CrossRef]

59. Park, J.H.; Yeo, S.Y.; Park, J.K.; Lee, Y.M. Electrochemical Performance of Lithium Sulfur Batteries with Plasticized Polymer Electrolytes based on P(VdF-co-HFP). J. Korean Electrochem. Soc. 2010, 13, 110-115. [CrossRef]

60. Ryu, H.S.; Choi, J.W.; Ahn, J.H.; Cho, G.B.; Ahn, H.J. The Electrochemical Properties of Poly(acrylonitrile) Polymer Electrolyte for Li/S Battery. Mater. Sci. Forum 2006, 510, 50-53. [CrossRef]

61. Shin, J.; Jung, B.; Jeong, S.; Kim, K.; Ahn, H.; Cho, K.; Ahn, J. Electrochemical and interfacial properties of $(\mathrm{PEO})_{10} \mathrm{LiCF}_{3} \mathrm{SO}_{3}-\mathrm{Al}_{2} \mathrm{O}_{3}$ nanocomposite polymer electrolytes using ball milling. Met. Mater. Int. 2004, 10, 177-183. [CrossRef]

62. Kolosnitsyn, V.S.; Karaseva, E.V.; Amineva, N.A.; Batyrshina, G.A. Cycling Lithium-Sulfur Batteries. Russ. J. Electrochem. 2002, 38, 329-331. [CrossRef] 
63. Shin, J.H.; Kim, K.W.; Ahn, H.J.; Ahn, J.H. Electrochemical properties and interfacial stability of $(\mathrm{PEO})_{10} \mathrm{LiCF}_{3} \mathrm{SO}_{3}-\mathrm{TinO}_{2 \mathrm{n}-1}$ composite polymer electrolytes for lithium/sulfur battery. Mater. Sci. Eng. B Solid State Mater. Adv. Technol. 2002, 95, 148-156. [CrossRef]

64. Zhu, X.J.; Wen, Z.Y.; Gu, Z.H.; Lin, Z.X. Electrochemical characterization and performance improvement of lithium/sulfur polymer batteries. J. Power Sources 2005, 139, 269-273. [CrossRef]

65. Choi, J.W.; Kim, J.H.; Cheruvally, G.; Ahn, J.H.; Kim, K.W.; Ahn, H.J.; Kim, J.U. Microporous Poly(vinylidene fluoride-co-hexafluoropropylene) Polymer Electrolytes for Lithium/Sulfur Cells. J. Ind. Eng. Chem. 2006, 12, 939-949.

66. Jeong, S.S.; Lim, Y.T.; Choi, Y.J.; Cho, G.B.; Kim, K.W.; Ahn, H.J.; Cho, K.K. Electrochemical properties of lithium sulfur cells using PEO polymer electrolytes prepared under three different mixing conditions. J. Power Sources 2007, 174, 745-750. [CrossRef]

67. Ahn, H.J.; Kim, K.W.; Ahn, J.H.; Cheruvally, G. Secondary Batteries—Lithium rechargeable systems: Lithium-sulfur. In Encyclopedia of Electrochemical Power Sources; Elsevier: Amsterdam, The Netherlands, 2010.

68. Hassoun, J.; Scrosati, B. Moving to a Solid-State Configuration: A Valid Approach to Making Lithium-Sulfur Batteries Viable for Practical Applications. Adv. Mater. 2010, 22, 5198-5201. [CrossRef] [PubMed]

69. Hassoun, J.; Scrosati, B. A High-Performance Polymer Tin Sulfur Lithium Ion Battery. Angew. Chem. Int. Ed. 2010, 49, 2371-2374. [CrossRef] [PubMed]

70. Hayashi, A.; Ohtomo, T.; Mizuno, F.; Tadanaga, K.; Tatsumisago, M. All-solid-state Li/S batteries with highly conductive glass-ceramic electrolytes. Electrochem. Commun. 2003, 5, 701-705. [CrossRef]

71. Hayashi, A.; Ohtsubo, R.; Ohtomo, T.; Mizuno, F.; Tatsumisago, M. All-solid-state rechargeable lithium batteries with $\mathrm{Li}_{2} \mathrm{~S}$ as a positive electrode material. J. Power Sources 2008, 183, 422-426. [CrossRef]

72. Kobayashi, T.; Imade, Y.; Shishihara, D.; Homma, K.; Nagao, M.; Watanabe, R.; Yokoi, T.; Yamada, A.; Kanno, R.; Tatsumi, T. All solid-state battery with sulfur electrode and thio-LISICON electrolyte. J. Power Sources 2008, 182, 621-625. [CrossRef]

73. Machida, N.; Kobayashi, K.; Nishikawa, Y.; Shigematsu, T. Electrochemical properties of sulfur as cathode materials in a solid-state lithium battery with inorganic solid electrolytes. Solid State Ion. 2004, 175, 247-250. [CrossRef]

74. Machida, N.; Shigematsu, T. An All-solid-state Lithium Battery with Sulfur as Positive Electrode Materials. Chem. Lett. 2004, 33, 376-377. [CrossRef]

75. Pradel, A.; Ribes, M. Electrical properties of lithium conductive silicon sulfide glasses prepared by twin roller quenching. Solid State Ion. 1986, 18, 351-355. [CrossRef]

76. Minami, K.; Mizuno, F.; Hayashi, A.; Tatsumisago, M. Lithium ion conductivity of the $\mathrm{Li}_{2} \mathrm{~S}_{-} \mathrm{P}_{2} \mathrm{~S}_{5}$ glass-based electrolytes prepared by the melt quenching method. Solid State Ion. 2007, 178, 837-841. [CrossRef]

77. Hedya, S.A.; Avula, A.; Swoboda, H.D. Lithium Toxicity. In StatPearls; StatPearls Publishing: Treasure Island, FL, USA, 2020. Available online: https://www.ncbi.nlm.nih.gov/books/NBK499992/ (accessed on 20 May 2020).

78. Central Drug House (P) Ltd. Lithium Metal. CAS No.: 7439-93-2. Material Safety Data Sheet. 2020. Available online: www.cdhfinechemical.com (accessed on 20 May 2020).

79. Ji, X.L.; Lee, K.T.; Nazar, L.F. A highly ordered nanostructured carbon-sulphur cathode for lithium-sulphur batteries. Nat. Mater. 2009, 8, 500-506. [CrossRef] [PubMed]

80. Guo, J.C.; Xu, Y.H.; Wang, C.S. Sulfur-impregnated disordered carbon nanotubes cathode for lithium-sulfur batteries. Nano Lett. 2011, 11, 4288-4294. [CrossRef] [PubMed]

81. Xin, S.; Gu, L.; Zhao, N.-H.; Yin, Y.-X.; Zhou, L.-J.; Guo, Y.-G.; Wan, L.-J. Smaller sulfur molecules promise better lithium-sulfur batteries. J. Am. Chem. Soc. 2012, 134, 18510-18513. [CrossRef] [PubMed]

82. Wang, L.; Wang, D.; Zhang, F.X.; Jin, J. Interface chemistry guided long-cycle-life Li-S battery. Nano Lett. 2013, 13, 4206-4211. [CrossRef]

83. Pang, Q.; Kundu, D.; Cuisinier, M.; Nazar, L.F. Surface-enhanced redox chemistry of polysulphides on a metallic and polar host for lithium-sulphur batteries. Nat. Commun. 2014, 5, 4759. [CrossRef]

84. She, Z.W.; Li, W.; Cha, J.J.; Zheng, G.; Yang, Y.; McDowell, M.T.; Hsu, P.-C.; Cui, Y. Sulphur-TiO 2 yolk-shell nanoarchitecture with internal void space for long-cycle lithium-sulphur batteries. Nat. Commun. 2013, 4, 1331.

85. Zhou, W.D.; Yu, Y.C.; Chen, H.; DiSalvo, F.J.; Abruña, H.D. Yolk-shell structure of polyaniline-coated sulfur for lithium-sulfur batteries. J. Am. Chem. Soc. 2013, 135, 16736-16743. [CrossRef]

86. Yang, Y.; Yu, G.; Cha, J.J.; Wu, H.; Vosgueritchian, M.; Yao, Y.; Bao, Z.; Cui, Y. Improving the performance of lithium-sulfur batteries by conductive polymer coating. ACS Nano 2011, 5, 9187-9193. [CrossRef] 
87. Chen, H.W.; Wang, C.; Dai, Y.; Qiu, S.; Yang, J.; Lu, W.; Chen, L. Rational design of cathode structure for high rate performance lithium-sulfur batteries. Nano Lett. 2015, 15, 5443-5448. [CrossRef]

88. She, Z.W.; Yu, J.H.; Li, W.; Hsu, P.-C.; Wang, H.; Sun, Y.; Yao, H.; Zhang, Q.; Cui, Y. Two-dimensional layered transition metal disulphides for effective encapsulation of high-capacity lithium sulphide cathodes. Nat. Commun. 2014, 5, 5017.

89. Su, Y.S.; Manthiram, A. Lithium-sulphur batteries with a microporous carbon paper as a bifunctional interlayer. Nat. Commun. 2012, 3, 1166. [CrossRef] [PubMed]

90. Zhou, G.M.; Pei, S.; Li, L.; Wang, D.-W.; Wang, S.; Huang, K.; Yin, L.-C.; Li, F.; Cheng, H.-M. A graphene-pure-sulfur sandwich structure for ultrafast, long-life lithium-sulfur batteries. Adv. Mater. 2014, 26, 625-631. [CrossRef] [PubMed]

91. Li, Y.J.; Fan, J.M.; Zheng, M.S.; Dong, Q.F. A novel synergistic composite with multi-functional effects for high-performance Li-S batteries. Energy Env. Sci. 2016, 9, 1998-2004. [CrossRef]

92. Rehman, S.; Gu, X.; Khan, K.; Mahmood, N.; Yang, W.; Huang, X.; Guo, S.; Hou, Y. 3D vertically aligned and interconnected porous carbon nanosheets as sulfur immobilizers for high performance lithium-sulfur batteries. Adv. Energy Mater. 2016, 6, 1502518. [CrossRef]

93. Pei, F.; An, T.; Zang, J.; Zhao, X.; Fang, X.; Zheng, M.; Dong, Q.; Zheng, N. From hollow carbon spheres to $\mathrm{N}$-doped hollow porous carbon bowls: Rational design of hollow carbon host for Li-S batteries. Adv. Energy Mater. 2016, 6, 1502539. [CrossRef]

94. Lenntech BV. Chemical properties of carbon-Health effects of carbon-Environmental effects of carbon. 2020. Available online: https://www.lenntech.com/periodic/elements/c.htm (accessed on 20 May 2020).

95. Sun, J.; Huang, Y.Q.; Wang, W.K.; Yu, Z.B.; Wang, A.B.; Yuan, K.G. Application of gelatin as a binder for the sulfur cathode in lithium-sulfur batteries. Electrochim. Acta 2008, 53, 7084-7088. [CrossRef]

96. Frischmann, P.D.; Hwa, Y.; Cairns, E.J.; Helms, B.A. Redox-Active Supramolecular Polymer Binders for Lithium-Sulfur Batteries That Adapt Their Transport Properties in Operando. Chem. Mater. 2016, 28, 7414-7421. [CrossRef]

97. Kurt J Lesker Company. Aluminum (pieces). CAS No.: 7429-90-5. Safety Data Sheet. 2018. Available online: http://www.nano.pitt.edu/sites/default/files/MSDS/Metals/Al-Aluminium.pdf (accessed on 22 May 2020).

98. Exley, C. The toxicity of aluminium in humans. Morphologie 2016, 100, 51-55. [CrossRef]

99. Duan, X.; Han, Y.; Li, Y.; Chen, Y. Improved capacity retention of low cost sulfur cathodes enabled by a novel starch binder derived from food. RSC Adv. 2014, 4, 60995-61000. [CrossRef]

100. Lacey, M.J.; Jeschull, F.; Edström, K.; Brandell, D. Why PEO as a binder or polymer coating increases capacity in the Li-S system. Chem. Commun. 2013,49, 8531-8533. [CrossRef]

101. Pan, J.; Xu, G.; Ding, B.; Han, J.; Dou, H.; Zhang, X. Enhanced electrochemical performance of sulfur cathodes with a water-soluble binder. RSC Adv. 2015, 5, 13709-13714. [CrossRef]

102. Chen, Y.; Liu, N.; Shao, H.; Wang, W.; Gao, M.; Li, C.; Zhang, H.; Wang, A.; Huang, Y. Chitosan as a functional additive for high-performance lithium-sulfur batteries. J. Mater. Chem. A 2015, 3, 15235-15240. [CrossRef]

103. Li, G.; Ling, M.; Ye, Y.; Li, Z.; Guo, J.; Yao, Y.; Zhu, J.; Lin, Z.; Zhang, S. Acacia senegal-inspired bifunctional binder for longevity of lithium-sulfur batteries. Adv. Energy Mater. 2015, 5, 1500878. [CrossRef]

104. Li, G.; Cai, W.; Liu, B.; Li, Z. A multi functional binder with lithium ion conductive polymer and polysulfide absorbents to improve cycleability of lithium-sulfur batteries. J. Power Sources 2015, 294, 187-192. [CrossRef]

105. Polyethylene Oxide. American Polymer Standards Corporation. 2019. Available online: http://www. ampolymer.com/SDS/PolyethyleneOxideSDS.html (accessed on 20 May 2020).

106. Gelatin. Drugbank. 2020. Available online: https://www.drugbank.ca/drugs/DB11242 (accessed on 20 May 2020).

107. Toxicity Profile for Polyvinylpyrrolidone. 1991. Available online: https://www.bibra-information.co.uk/ downloads/toxicity-profile-for-polyvinylpyrrolidone-1991/ (accessed on 20 May 2020).

108. Carl Roth GmbH + Co KG. Polyvinylpyrrolidone K 30 extra pure. CAS No.: 9003-39-8. Safety Data Sheet. 2018. Available online: www.carlroth.de (accessed on 20 May 2020).

109. Anderson, D.M.; Brydon, W.G.; Eastwood, M.A.; Sedgwick, D.M. Dietary effects of sodium alginate in humans. Food Addit. Contam. 1991, 8, 237-248. [CrossRef] [PubMed]

110. Abdelgadir, A.E. Assessment of Toxicity and Influence of Three Types of Gum Arabic on Blood Glucose, Body Weight, Total Protein and Lipid Profile on Diabetic Rats. Int. J. Adv. Res. 2013, 1, 13-19. 
111. Thermo Fisher Scientific. Gum Arabic. CAS No.: 9000-01-5. Safety Data Sheet. 2018. Available online: https://www.fishersci.com/store/msds?partNumber=AC258850010\&productDescription=GUM+ ARABIC+1KG\&vendorId=VN00032119\&countryCode=US\&language=en (accessed on 22 May 2020).

112. Carl Roth GmbH + Co KG. Gum Arabic, spray dried. CAS No.: 9000-01-5. Safety Data Sheet, Version: 1.0. 2019. Available online: https://www.carlroth.com/downloads/sdb/en/4/SDB_4159_GB_EN.pdf (accessed on 22 May 2020).

113. Inderherbergh, J. Polyvinylidene Fluoride (PVDF) Appearance, General Properties and Processing. Ferroelectrics 1991, 115, 295-302. [CrossRef]

114. Fluorochem Ltd. Poly(vinylidene fluoride). CAS No.: 24937-79-9. Safety Data Sheet. 2011. Available online: http://www.fluorochem.co.uk/System/DownloadSDS?fileName=(EN)007211_1.00.pdf (accessed on 22 May 2020).

115. Feng, M.; Qu, R.; Habteselassie, M.; Wu, J.; Yang, S.; Sun, P.; Huang, Q.; Wang, Z. Hepatic Transcriptome Responses in Mice (Mus musculus) Exposed to the Nafion Membrane and Its Combustion Products. PLOS ONE 2015, 10, e0128591. [CrossRef]

116. Nafion Cast Membranes. Article Information Sheet, Version 4.0. Chemours, Ref. 150000003570. 2015. Available online: https://www.nafion.com/en/products/sulfonic-membranes (accessed on 22 May 2020).

117. SynQuest Laboratories, Inc. Nafion NR50. Safety Data Sheet 6198308. 2019. Available online: www. synquestlabs.com (accessed on 20 May 2020).

118. Sigma-Aldrich. PAMAM dendrimer. Safety Data Sheet, version 3.10. 2016. Available online: www.sigmaaldrich.com (accessed on 20 May 2020).

119. Albertazzi, L.; Gherardini, L.; Brondi, M.; Sulis Sato, S.; Bifone, A.; Pizzorusso, T.; Ratto, G.M.; Bardi, G. In Vivo Distribution and Toxicity of PAMAM Dendrimers in the Central Nervous System Depend on Their Surface Chemistry. Mol. Pharm. 2013, 10, 249-260. [CrossRef]

120. Cryan, S.A.; Holohan, A.; Donohue, R.; Darcy, R.; O’Driscoll, C. Cell transfection with polycationic cyclodextrin vectors. Eur. J. Pharm. Sci. Off. J. Eur. Fed. Pharm. Sci. 2004, 21, 625-633. [CrossRef]

121. Varan, G.; Benito, J.M.; Mellet, C.O.; Bilensoy, E. Development of polycationic amphiphilic cyclodextrin nanoparticles for anticancer drug delivery. Beilstein J. Nanotechnol. 2017, 8, 1457-1468. [CrossRef] [PubMed]

122. Gerloczy, A.; Hoshino, T.; Pitha, J. Safety of oral cyclodextrins: Effects of hydroxypropyl cyclodextrins, cyclodextrin sulfates and cationic cyclodextrins on steroid balance in rats. J. Pharm. Sci. 1994, 83, 193-196. [CrossRef] [PubMed]

123. Terao, K. Poly(acrylic acid) (PAA). In Encyclopedia of Polymeric Nanomaterials; Kobayashi, S., Müllen, K., Eds.; Springer: Berlin/Heidelberg, Germany, 2015.

124. World Health Organization. Acrylic Acid Environmental Health Criteria; No 191; World Health Organization: Geneva, Switzerland, 1997.

125. Spectrum Chemical Mfg. Corp. Carboxymethyl Cellulose Sodium. CAS No.: 9004-32-4. Safety Data Sheet. 2015. Available online: https://www.spectrumchemical.com (accessed on 20 May 2020).

126. Mondal, M.I.; Yeasmin, M.S. Toxicity study of food-grade carboxymethyl cellulose synthesized from maize husk in Swiss albino mice. Int. J. Biol. Macromol. 2016, 92, 965-971. [CrossRef] [PubMed]

127. Patterson, D.L.; Yunginger, J.W.; Dunn, W.F.; Jones, R.T.; Hunt, L.W. Anaphylaxis induced by the carboxymethylcellulose component of injectable triamcinolone acetonide suspension (Kenalog). Ann. Allergy Asthma Immunol. 1995, 74, 163-166.

128. Healy, M. Is common food additive to blame for rising rates of bowel disease? Los Angeles Times. 25 February 2015. Available online: https://www.latimes.com/science/sciencenow/la-sci-sn-metabolic-bowel-emulsifiers20150225-story.html (accessed on 22 May 2020).

129. Martino, J.V.; van Limbergen, J.; Cahill, L.E. The Role of Carrageenan and Carboxymethylcellulose in the Development of Intestinal Inflammation. Front. Pediatrics 2017, 5, 96. [CrossRef]

130. Fieldturf, T. Debunking the Myth of SBR Dangers Tire Crumb Rubber Use in Artificial Turf Fields: The Latest in a Long List of Scare Tactics; ADEME/ALIAPUR/FIELDTURF TARKETT; Däckindustrin: Upplands Väsby, Sweeden, 2004.

131. Kim, N.-I.; Lee, C.-B.; Seo, J.-M.; Lee, W.-J.; Roh, Y.-B. Correlation between positive-electrode morphology and sulfur utilization in lithium-sulfur battery. J. Power Sources 2004, 132, 209-212. [CrossRef]

132. Ryu, H.-S.; Ahn, H.-J.; Kim, K.-W.; Ahn, J.-H.; Cho, K.-K.; Nam, T.-H.; Kim, J.-U.; Cho, G.-B. Discharge behavior of lithium/sulfur cell with TEGDME based electrolyte at low temperature. J. Power Sources 2006, 163, 201-206. [CrossRef] 
133. Jung, Y.J.; Kim, S. New approaches to improve cycle life characteristics of lithium-sulfur cells. Electrochem. Commun. 2007, 9, 249-254. [CrossRef]

134. Wang, W.K.; Wang, Y.; Huang, Y.Q.; Huang, C.J.; Yu, Z.B.; Zhang, H.; Wang, A.B.; Yuan, K.G. The electrochemical performance of lithium-sulfur batteries with LiClO DOL/DME electrolyte. J. Appl. Electrochem. 2010, 40, 321-325. [CrossRef]

135. Sun, J.; Huang, Y.Q.; Wang, W.K.; Yu, Z.B.; Wang, A.B.; Yuan, K.G. Preparation and electrochemical characterization of the porous sulfur cathode using a gelatin binder. Electrochem. Commun. 2008, 10, 930-933. [CrossRef]

136. Zhang, W.Y.; Huang, Y.Q.; Wang, W.K.; Huang, C.J.; Wang, Y.; Yu, Z.B.; Zhang, H. Influence of pH of Gelatin Solution on Cycle Performance of the Sulfur Cathode. J. Electrochem. Soc. 2010, 157, A443-A446. [CrossRef]

137. Sajid, M.; Ilyas, M. PTFE-coated non-stick cookware and toxicity concerns: A perspective. Environ. Sci. Pollut. Res. Int. 2017, 24, 23436-23440. [CrossRef] [PubMed]

138. Shimizu, T.; Hamada, O.; Sasaki, A.; Ikeda, M. Polymer fume fever. BMJ Case Reports 2012, bcr2012007790. Available online: https://pubmed.ncbi.nlm.nih.gov/23230259/ (accessed on 22 May 2020).

139. HaloPolymer Kirovo-Chepetsk, LLC. Polytetrafluoroethylene. CAS No.: 9002-84-0. Safety Data Sheet. 2017. Available online: www.halopolymer.com (accessed on 20 May 2020).

140. BrookeTaylor, S.; Verger, P. Polyvinyl Alcohol. WHO Food Additives Series: 52, JECFA 52. Inchem. 2004. Available online: http://www.inchem.org/documents/jecfa/jecmono/v52je09.htm (accessed on 20 May 2020).

141. DeMerlis, C.C.; Schoneker, D.R. Review of the oral toxicity of polyvinyl alcohol (PVA). Food Chem. Toxicol. 2003, 41, 319-326. [CrossRef]

142. American Polymer Standards Corporation. Polyvinyl Alcohol. CAS No.: 9002-89-5. 2014. Available online: http://www.ampolymer.com/SDS/PolyvinylAlcoholSDS.html (accessed on 20 May 2020).

143. Peled, E.; Goor, M.; Schektman, I.; Mukra, T.; Shoval, Y.; Golodnitsky, D. The Effect of Binders on the Performance and Defradation of the Lithium/Sulfur Battery Assembled in the Discharged State. J. Electrochem. Soc. 2017, 164, A5001-A5007. [CrossRef]

144. American Polymer Standards Corporation. Vinylidene Fluoride-Hexafluoropropylene PVDF-HFP2. CAS No.: 9011-17-0. Safety Data Sheet. 2014. Available online: http://www.ampolymer.com/SDS/VinylideneFluorideHexafluoropropyleneSDS.html (accessed on 22 May 2020).

145. BASF SE. Lupasol PS. Safety Data Sheet. 2016. Available online: https://www.chempoint.com/products/ download? grade $=4849 \&$ type $=$ sds (accessed on 22 May 2020).

146. Johnson Matthey Company Inc. Polyaniline. Material Safety Data Sheet. Alfa Aesar, Johnson Matthey Catalog Company, 2009. Available online: www.alfa.com (accessed on 20 May 2020).

147. Ibarra, L.E.; Tarres, L.; Bongiovanni, S.; Barbero, C.A.; Kogan, M.J.; Rivarola, V.A.; Bertuzzi, M.L.; Yslas, E.I. Assessment of polyaniline nanoparticles toxicity and teratogenicity in aquatic environment using Rhinella arenarum model. Ecotoxicol. Environ. Saf. 2015, 114, 84-92. [CrossRef]

148. Humpolíček, P.; Radaszkiewicz, K.A.; Capáková, Z.; Pacherník, J.; Bober, P.; Kašpárková, V.; Rejmontová, P.; Lehocký, M.; Ponížil, P.; Stejskal, J. Polyaniline cryogels: Biocompatibility of novel conducting macroporous material. Sci. Rep. 2018, 8, 135. [CrossRef]

149. He, X.; Yan, B.; Zhang, X.; Liu, Z.; Bresser, D.; Wang, J.; Wang, R.; Cao, X.; Su, Y.; Jia, H.; et al. Fluorine-free water-in-ionomer electrolytes for sustainable lithium-ion batteries. Nat. Commun. 2018, 9, 5320. [CrossRef]

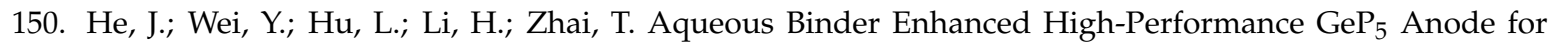
Lithium-Ion Batteries. Front. Chem. 2018, 6, 21. [CrossRef]

151. BK Giulini GmbH. Lithium polyacrylate. Safety Data Sheet. 2015. Available online: www.icl-pp.com (accessed on 20 May 2020).

152. Zhang, S.S. Binder Based on Polyelectrolyte for High Capacity Density Lithium/Sulfur Battery. J. Electrochem. Soc. 2012, 159, A1226-A1229. [CrossRef]

153. GuideChem. Poly(acrylamide-co-diallyl dimethyl ammonium chloride). CAS No.: 26590-05-6. Safety Data Sheet. 2017. Available online: www.guidechem.com (accessed on 20 May 2020).

154. Exon, J.H. A review of the toxicology of acrylamide. J. Toxicol. Env. Health B Crit. Rev. 2006, 9, $397-412$. [CrossRef]

155. National Center for Biotechnology Information. PubChem Database. CID=33286. Available online: https: //pubchem.ncbi.nlm.nih.gov/compound/Diallyldimethylammonium-chloride (accessed on 11 May 2020). 
156. Hwa, Y.; Frischmann, P.D.; Helms, B.A.; Cairns, E.J. Aqueous-Processable Redox-Active Supramolecular Polymer Binders for Advanced Lithium/Sulfur Cells. Chem. Mater. 2018, 30, 685-691. [CrossRef]

157. Jiao, Y.; Chen, W.; Lei, T.; Dai, L.; Chen, B.; Wu, C.; Xiong, J. A Novel Polar Copolymer Design as a Multi-Functional Binder for Strong Affinity of Polysulfides in Lithium-Sulfur Batteries. Nanoscale Res. Lett. 2017, 12, 195. [CrossRef] [PubMed]

158. Wang, L.; Lee, S.-Y.; Wu, S.-C.; Chen, H.; Tsai, L.-L.; Tzeng, J.-J.; Lin, C.-H.; Lin, Y.-M. Synthesis and Characterization of Polycaprolactone-Based Polyurethanes for the Fabrication of Elastic Guided Bone Regeneration Membrane. Biomed. Res. Int. 2018, 3240571. [CrossRef]

159. Cary, R.; Dobson, S.; Delic, J. 1,2-Diaminoethane (Ethylenediamine). Concise International Chemical Assessment Document 15; World Health Organization: Geneva, Switzerland, 1999.

160. Cheng, M.; Liu, Y.; Guo, X.; Wu, Z.; Chen, Y.; Li, J.; Li, L.; Zhong, B. A novel binder-sulfonated polystyrene for the sulfur cathode of Li-S batteries. Ionics 2017, 23, 2251-2258. [CrossRef]

161. Rogers, F.B.; Li, S.C. Acute colonic necrosis associated with sodium polystyrene sulfonate (Kayexalate) enemas in a critically ill patient: Case report and review of the literature. J. Trauma 2001, 51, 395-397. [CrossRef] [PubMed]

162. Zhang, S.S. Improved cyclability of liquid electrolyte lithium/sulfur batteries by optimizing electrolyte/sulfur ratio. Energies 2012, 5, 5190-5197. [CrossRef]

163. Carbone, L.; Gobet, M.; Peng, J.; Devany, M.; Scrosati, B.; Greenbaum, S.; Hassoun, J. Comparative study of ether-based electrolytes for application in lithium-sulfur battery. ACS Appl. Mater. Interfaces 2015, 7, 13859-13865. [CrossRef]

164. Gao, J.; Lowe, M.A.; Kiya, Y.; Abruña, H.D. Effects of liquid electrolytes on the charge-discharge performance of rechargeable lithium/sulfur batteries: Electrochemical and in-situ X-ray absorption spectroscopic studies. J. Phys. Chem. C 2011, 115, 25132-25137. [CrossRef]

165. Zhang, S.S. Liquid electrolyte lithium/sulfur battery: Fundamental chemistry, problems, and solutions. J. Power Sources 2013, 231, 153-162. [CrossRef]

166. Kim, H.-S.; Jeong, C.-S. Electrochemical properties of binary electrolytes for lithium-sulfur batteries. Bull. Korean Chem. Soc. 2011, 32, 3682-3686. [CrossRef]

167. Aurbach, D.; Youngman, O.; Dan, P. The electrochemical-behavior of 1,3-dioxolane-LiClO4 solutions. 2. Contaminated solutions. Electrochim. Acta 1990, 35, 639-655. [CrossRef]

168. Aurbach, D.; Youngman, O.; Gofer, Y.; Meitav, A. The electrochemical-behavior of 1,3-dioxolane-LiCLO4 solutions. 1. Uncontaminated solutions. Electrochim. Acta 1990, 35, 625-638. [CrossRef]

169. Gofer, Y.; Ely, Y.E.; Aurbach, D. Surface-chemistry of lithium in 1,3-dioxolane. Electrochim. Acta 1992, 37, 1897-1899. [CrossRef]

170. National Center for Biotechnology Information. PubChem Database. CID=3816071. Available online: https://pubchem.ncbi.nlm.nih.gov/compound/Lithium-bis_trifluoromethyl_sulfonyl_azanide\# datasheet=LCSS (accessed on 8 May 2020).

171. New Jersey Department of Health and Senior Services. Dimethyl Ether. CAS No.: 115-10-6. Hazardous Substance Fact Sheet; 1996. Available online: http://www.nj.gov/health/eoh/rtkweb/documents/fs/0758.pdf (accessed on 22 May 2020).

172. Praxair, Inc. Dimethyl Ether. CAS No.: 115-10-6. Safety Data Sheet P-4589. 2016. Available online: www.praxair.com (accessed on 20 May 2020).

173. ECHA. 1,3-dioxolane. CAS No.: 646-06-0. 2013. Available online: https://echa.europa.eu/registration-dossier/ -/registered-dossier/15807/7/13 (accessed on 20 May 2020).

174. Central Drug House (P) Ltd. 1,3-dioxolane. CAS No.: 646-06-0. Safety Data SheetCAS No.: 646-06-0. Safety Data Sheet. 2019. Available online: www.cdhfinechemical.com (accessed on 20 May 2020).

175. Ryu, H.S.; Ahn, H.J.; Kim, K.W.; Ahn, J.H.; Lee, J.Y.; Cairns, E.J. Self-discharge of lithium-sulfur cells using stainless-steel current-collectors. J. Power Sources 2005, 140, 365-369. [CrossRef]

176. Tobishima, S.-I.; Yamamoto, H.; Matsuda, M. Study on the reduction species of sulfur by alkali metals in nonaqueous solvents. Electrochim. Acta 1997, 42, 1019-1029. [CrossRef]

177. Yamin, H.; Gorenshtein, A.; Penciner, J.; Sternberg, Y.; Peled, E. Lithium Sulfur Battery Oxidation/Reduction Mechanisms of Polysulfides in THF Solutions. J. Electrochem. Soc. 1988, 135, 1045-1048. [CrossRef]

178. Kim, S.; Jung, Y.J.; Park, S.J. Effects of imidazolium salts on discharge performance of rechargeable lithium-sulfur cells containing organic solvent electrolytes. J. Power Sources 2005, 152, 272-277. [CrossRef] 
179. Ryu, H.S.; Ahn, H.J.; Kim, K.W.; Ahn, J.H.; Cho, K.K.; Nam, T.H. Self-discharge characteristics of lithium/sulfur batteries using TEGDME liquid electrolyte. Electrochim. Acta 2006, 52, 1563-1566. [CrossRef]

180. Choi, J.W.; Cheruvally, G.; Kim, D.S.; Ahn, J.H.; Kim, K.W.; Ahn, H.J. Rechargeable lithium/sulfur battery with liquid electrolytes containing toluene as additive. J. Power Sources 2008, 183, 441-445. [CrossRef]

181. Shim, J.; Striebel, K.A.; Cairns, E.J. The lithium/sulfur rechargeable cell. J. Electrochem. Soc. 2002, 149 , A1321. [CrossRef]

182. Barchasz, C.; Lepretre, J.C.; Patoux, S.; Alloin, F. Electrochemical properties of ether-based electrolytes for lithium/sulfur rechargeable batteries. Electrochim. Acta 2013, 89, 737-743. [CrossRef]

183. Nimon, Y.; Visco, S.J.; Chu, M.-Y. Dioxolane as a proctector for lithium electrodes. U.S. Patent 6,225,002, 1 May 2001.

184. Zhao, X.; Cheruvally, G.; Kim, C.; Cho, K.-K.; Ahn, H.-J.; Kim, K.-W.; Ahn, J.-H. Lithium/Sulfur Secondary Batteries: A Review. J. Electrochem. Sci. Technol. 2016, 7, 97-114. [CrossRef]

185. Barghamadi, M. Electrochemistry and speciation of sulfur/polysulfides in ionic liquid-based lithium sulfur batteries. Ph.D. Thesis, Swinburne University of Technology, Melbourne, Australia, 2016.

186. Barchasz, C.; Lepretre, J.C.; Patoux, S.; Alloin, F. Revisiting TEGDME/DIOX binary electrolytes for lithium/sulfur batteries: Importance of solvation ability and additives. J. Electrochem. Soc. 2013, 160, A430-CA436. [CrossRef]

187. Kim, S.; Jung, Y.; Lim, H.S. The effect of solvent component on the discharge performance of lithium-sulfur cell containing various organic electrolytes. Electrochim. Acta 2004, 50, 889-892. [CrossRef]

188. Song, M.S.; Han, S.C.; Kim, H.S.; Kim, J.H.; Kim, K.T.; Kang, Y.M.; Ahn, H.J.; Dou, S.X.; Lee, J.Y. Effects of Nanosized Adsorbing Material on Electrochemical Properties of Sulfur Cathodes for Li/S Secondary Batteries. J. Electrochem. Soc. 2004, 151, A791-A795. [CrossRef]

189. Fowles, J.; Boatman, R.; Bootman, J.; Lewis, C.; Morgott, D.; Rushton, E.; van Rooij, J.; Banton, M. A review of the toxicological and environmental hazards and risks of tetrahydrofuran. Crit. Rev. Toxicol. 2013, 43, 811-828. [CrossRef]

190. Carl Roth GmbH + Co KG. Tetrahydrofuran. CAS No.: 109-99-9. Safety Data Sheet. 2016. Available online: www.carlroth.de (accessed on 20 May 2020).

191. Kruse, J.A. Methanol and Ethylene Glycol Intoxication. Crit. Care Clin. 2012, 28, 661-711. [CrossRef]

192. Carl Roth GmbH + Co KG. Ethylene glycol. CAS No.: 107-21-1. Safety Data Sheet, Version 4.0. 2015. Available online: www.carlroth.de (accessed on 20 May 2020).

193. Triethylene glycol. The MAK-Collection Part I. MAK Value Documentations. 2014. Available online: https://onlinelibrary.wiley.com/doi/pdf/10.1002/3527600418.mb11227e4214 (accessed on 20 May 2020).

194. National Center for Biotechnology Information. PubChem Database. Triglyme, CID=8189. Available online: https://pubchem.ncbi.nlm.nih.gov/compound/Triglyme (accessed on 12 May 2020).

195. Glycol Ethers Charter. Glycol Ethers Online. 2020. Available online: https:/www.glycol-ethers.eu/glycolethers-charter/ (accessed on 20 May 2020).

196. Kupczewska-Dobecka, M. Bis(2-methoxyethyl) ether. Podstawy I Metod. Oceny Środowiska Pr. 2011, 4, 43-69.

197. 1,2-bis(2-methoxyethoxy)ethane (Triglyme). Proposal for Identification of a Substance as a Category 1A or 1B CMR, PBT, vPvB or a Substance of an Equivalent Level of Concern, Annex XV-Identification of Triglyme (TEGDME) as SVHC, Belgian Federal Public Service (FPS) Health, Food Chain Safety and Environment, Risk Management Service. 2020. Available online: https://echa.europa.eu/documents/10162/7c7d5fc7-53a1-e4d855fb-9229d5248c57 (accessed on 22 May 2020).

198. Melody, B.J.; Kinard, J.T.; Wheeler, D.A. Anodizing electrolyte and its use. U.S. Patent 5716511A, 10 February 1998.

199. Sigma-Aldrich. Polyethylene Glycol 2000 Dimethyl Ether. CAS No.: 24991-55-7. Material Safety Data Sheet, Version 1.5. 2006. Available online: www.sigma-aldrich.com (accessed on 20 May 2020).

200. 2-Ethoxyethyl ether. Chemical Book. 2017. Available online: https://www.chemicalbook.com/ ChemicalProductProperty_EN_cb4669548.htm (accessed on 20 May 2020).

201. Diethylene Glycol Dimethyl Ether. Concise International Chemical Assessment Document 41; World Health Organization: Geneva, Switzerland, 2002.

202. National Center for Biotechnology Information. PubChem Database. Diglyme, CID=8150. Available online: https://pubchem.ncbi.nlm.nih.gov/compound/Diglyme (accessed on 19 May 2020). 
203. Gillett, A.; Waugh, D.G.; Lawrence, J. 7-Laser surface modification of polymeric surfaces for microbiological applications. In Laser Surface Modification of Biomaterials; Vilar, R., Ed.; Woodhead Publishing: Sawston/Cambridge, UK, 2016; pp. 197-220.

204. Schier, J.; Barr, D.; Li, Z.; Wolkin, A.; Baker, S.; Lewis, L.; McGeehin, M. Diethylene Glycol in Health Products Sold Over-the-Counter and Imported from Asian Countries. J. Med. Toxicol. J. Am. Coll. Med. Toxicol. 2010, 7, 33-38.

205. Choi, J.W.; Kim, J.K.; Cheruvally, G.; Ahn, J.H.; Ahn, H.J.; Kim, K.W. Rechargeable lithium/sulfur battery with suitable mixed liquid electrolytes. Electrochim. Acta 2007, 52, 2075-2082. [CrossRef]

206. Methyl acetate. Wiley Online Library. 2002. Available online: https://onlinelibrary.wiley.com/doi/pdf/10. 1002/3527600418.mb7920e018 (accessed on 20 May 2020).

207. Eastman Chemical Company. Eastman Methyl Acetate. Safety Data Sheet, Version 2.2. 2016. Available online: http://ws.eastman.com/ProductCatalogApps/PageControllers/MSDS_PC.aspx?Product=71001121 (accessed on 22 May 2020).

208. Medical Management Guidelines for Toluene [C6H5CH3]. CAS 108-88-3. Toxic Substances Portal-Toluene. Agency for Toxic Substances and Disease Registry; 2019. Available online: https://www.atsdr.cdc.gov/MMG/ MMG.asp?id=157\&tid=29 (accessed on 20 May 2020).

209. LabChem Inc. Toluene. CAS-No.: 108-88-3. Safety Data Sheet, Version 1.1. 2014. Available online: www.labchem.com (accessed on 20 May 2020).

210. Gamma-Butyrolactone (GBL). Critical Review Report Agenda item 4.3. Expert Committee on Drug Dependence. In Proceedings of the Thirty-sixth Meeting of the World Health Organization, Geneva, Switzerland, 16-20 June 2014.

211. Gamma-Butyrolactone (GBL). Material Safety Data Sheet. Fred Holmberg \& Co AB, 2011. Available online: http://www.holmberg.se/upload/product/files/msds-gamma-butyrolactone-gbl-eng-2011-10-07--641.pdf (accessed on 22 May 2020).

212. Cho, C.W.; Pham, T.P.; Jeon, Y.C.; Vijayaraghavan, K.; Choe, W.S.; Yun, Y.S. Toxicity of imidazolium salt with anion bromide to a phytoplankton Selenastrum capricornutum: Effect of alkyl-chain length. Chemosphere 2007, 69, 1003-1007. [CrossRef] [PubMed]

213. Biczak, R.; Pawlowska, B.; Balczewski, P.; Rychter, P. The role of the anion in the toxicity of imidazolium ionic liquids. J. Hazard. Mater. 2014, 274C, 181-190. [CrossRef] [PubMed]

214. Sigma-Aldrich. Tetrabutylammonium hexafluorophosphate. Safety Data Sheet, Version 5.0. 2012. Available online: www.sigma-aldrich.com (accessed on 20 May 2020).

215. Chapter 5.3.1.-Lithium Salts. Future Lithium-ion Batteries. In Energy and Environment Series; Eftekhari, A. (Ed.) Royal Society of Chemistry: Cambridge, UK, 2019; p. 361.

216. Sigma-Aldrich. Lithium trifluoromethanesulfonate. Safety Data Sheet, Version 6.0. 2019. Available online: www.sigma-aldrich.com (accessed on 20 May 2020).

217. Zhu, J. Advanced Separator Selection and Design for High-Performance Lithium-Sulfur Batteries; North Carolina State University: Raleigh, NC, USA, 2016.

218. Foropoulos, M.; Lee, H.S.; Sun, X.; Yang, X.Q.; Moodenbaugh, A.R.; McBreen, J.; Fischer, D.A.; Fu, Z. Formation of SEI on cycled lithium-ion battery cathodes: Soft X-ray absorption study. Electrochem. SolidState Lett. 2002, 5, A22-A25.

219. Foropoulos, J.; Desmarteau, D.D. Synthesis, properties, and reactions of bis((trifluoromethyl)sulfonyl) imide, (Cf3so2)2nh. Inorg. Chem 1984, 23, 3720-3723. [CrossRef]

220. Xu, K. Nonaqueous liquid electrolytes for lithium-based rechargeable batteries. Chem. Rev. 2004, 104, 4303-4417. [CrossRef]

221. Scheers, J.; Fantini, S.; Johansson, P. A review of electrolytes for lithium-sulphur batteries. J. Power Sources 2014, 255, 204-218. [CrossRef]

222. Sigma-Aldrich. Bis (Trifluoromethane) Sulfonimide Lithium Salt. Safety Data Sheet, Version 6.0. 2019. Available online: www.sigmaaldrich.com (accessed on 20 May 2020).

223. Guerfi, A.; Duchesne, S.; Kobayashi, Y.; Vijh, A.; Zaghib, K. $\mathrm{LiFePO}_{4}$ and graphite electrodes with ionic liquids based on bis(fluorosulfonyl)imide (FSI) (-) for Li-ion batteries. J. Power Sources 2008, 175, 866-873. [CrossRef] 
224. Dudley, J.T.; Wilkinson, D.P.; Thomas, G.; LeVae, R.; Woo, S.; Blom, H.; Horvath, C.; Juzkow, M.W.; Denis, B.; Juric, P.; et al. Conductivity of electrolytes for rechargeable lithium batteries. J. Power Sources 1991, 35, 59-82. [CrossRef]

225. Xu, K.; Angell, C.A. Sulfone-based electrolytes for lithium-ion batteries. J. Electrochem. Soc. 2002, 149, A920-A926. [CrossRef]

226. KISHIDA Chemical CO Ltd. 1mol/L LiFSI EMI-FSI. Safety Data Sheet T794E-2,09/05/2017. 2017. Available online: http://www.kishida.co.jp/product/catalog/msds/id/20641/code/LBG-02315e.pdf (accessed on 22 May 2020).

227. Watson International Ltd. Lithium bis(fluorosulfonyl)imide, ultra dry. CAS No.: 171611-11-3. Safety Data Sheet. 2017. Available online: https://www.watson-int.com/wp-content/uploads/2017/10/MSDS-of-LiFSI171611-11-3.pdf (accessed on 22 May 2020).

228. Fisher Scientific. Alfa Aesar Lithium 4,5-dicyano-2-(trifluoromethyl)imidazole, 95\%. CAS 761441-54-7. 2020. Available online: https://www.fishersci.com/shop/products/lithium-4-5-dicyano-2-trifluoromethylimidazole-95/AAH3408103 (accessed on 20 May 2020).

229. National Center for Biotechnology Information. PubChem Database. Lithium perchlorate, CID=23665649. Available online: https://pubchem.ncbi.nlm.nih.gov/compound/Lithium-perchlorate (accessed on 20 May 2020).

230. Lithium perchlorate sc-215260. Material Safety Data Sheet. Santa Cruz Biotechnology Inc., 2009. Available online: http://datasheets.scbt.com/sc-215260.pdf (accessed on 22 May 2020).

231. Yuan, L.X.; Feng, J.K.; Ai, X.P.; Cao, Y.L.; Chen, S.L.; Yang, H.X. Improved dischargeability and reversibility of sulfur cathode in a novel ionic liquid electrolyte. Electrochem. Commun. 2006, 8, 610-614. [CrossRef]

232. Wang, J.; Chew, S.Y.; Zhao, Z.W.; Ashraf, S.; Wexler, D.; Chen, J.; Ng, S.H.; Chou, S.L.; Liu, H.K. Sulfur-mesoporous carbon composites in conjunction with a novel ionic liquid electrolyte for lithium rechargeable batteries. Carbon 2008, 46, 229-235. [CrossRef]

233. Shin, J.H.; Cairns, E.J. N-Methyl-(n-butyl)pyrrolidinium bis(trifluoromethanesulfonyl)imide-LiTFSI-poly (ethylene glycol) dimethyl ether mixture as a Li/S cell electrolyte. J. Power Sources 2008, 177, 537-545. [CrossRef]

234. Central Drug House (P) Ltd. Dimethyl Carbonate. CAS No.: 616-38-6. Material Safety Data Sheet. 2019. Available online: www.cdhfinechemical.com (accessed on 20 May 2020).

235. Kuenen, H.J.; Mengers, H.J.; van der Ham, A.G.J.; Kiss, A.A. Novel Process for Conversion of $\mathrm{CO}_{2}$ to Dimethyl Carbonate using Catalytic Membrane Reactors. In Computer Aided Chemical Engineering; Kravanja, Z., Bogataj, M., Eds.; Elsevier: Amsterdam, The Netherlands, 2016; Volume 38, pp. 991-996.

236. Shahzad, S.; Shah, A.; Kowsari, E.; Iftikhar, F.J.; Nawab, A.; Piro, B.; Akhter, M.S.; Rana, U.A.; Zou, Y. Ionic Liquids as Environmentally Benign Electrolytes for High-Performance Supercapacitors. Glob. Chall. 2019, 3 , 1800023. [CrossRef] [PubMed]

237. Sigma-Aldrich. 1-Butyl-1-methylpiperidinium bis(trifluoromethylsulfonyl)imide. Material Safety Data Sheet, Version 8.1. 2020. Available online: www.sigma-aldrich.com (accessed on 20 May 2020).

238. Park, J.-W.; Yamauchi, K.; Takashima, E.; Tachikawa, N.; Ueno, K.; Dokko, K.; Watanabe, M. Solvent effect of room temperature ionic liquids on electro- chemical reactions in lithium-sulfur batteries. J. Phys. Chem. C 2013, 117, 4431-4440. [CrossRef]

239. Sigma-Aldrich. Diethylmethyl(2-methoxyethyl)ammonium bis(trifluoromethylsulfonyl)imide. Material Safety Data Sheet, Version 6.0. 2019. Available online: www.sigma-aldrich.com (accessed on 20 May 2020).

240. Sigma-Aldrich. 1-ethyl-3-methylimidazoliumbis (trifluoromethanesulfonyl) imide. CAS No: 174899-82-2. Safety Data Sheet. 2019. Available online: www.sigmaaldrich.com (accessed on 20 May 2020).

241. Santa Cruz Biotechnology Inc. 1-ethyl-3-methylimidazoliumbis (trifluoromethanesulfonyl) imide. Material Safety Data Sheet sc-251507. 2009. Available online: http://datasheets.scbt.com/sc-251507.pdf (accessed on 22 May 2020).

242. Tachikawa, N.; Yamauchi, K.; Takashima, E.; Park, J.W.; Dokko, K.; Watanabe, M. Reversibility of electrochemical reactions of sulfur supported on inverse opal carbon in glyme-Li salt molten complex electrolytes. Chem. Commun. 2011, 47, 8157-8159. [CrossRef] [PubMed]

243. Yan, Y.; Yin, Y.X.; Xin, S.; Su, J.; Guo, Y.G.; Wan, L.J. High-safety lithium-sulfur battery with prelithiated Si/C anode and ionic liquid electrolyte. Electrochim. Acta 2013, 91, 58-61. [CrossRef]

244. TCI Chemicals. 1-Allyl-1-methylpyrrolidinium Bis(trifluoromethanesulfonyl)imide. CAS No.: 1059624-23-5. 2020. Available online: https://www.tcichemicals.com/SG/en/p/A3089 (accessed on 20 May 2020). 
245. Sigma-Aldrich. 1-Ethyl-3-methylimidazolium bis(pentafluoroethylsulfonyl)imide. Material Safety Data Sheet, Version 6.1. 2019. Available online: www.sigma-aldrich.com (accessed on 20 May 2020).

246. Sigma-Aldrich. 1-Butyl-3-methylimidazolium hexafluorophosphate. Material Safety Data Sheet, Version 6.0. 2019. Available online: www.sigma-aldrich.com (accessed on 20 May 2020).

247. Wang, J.; Wang, Y.W.; He, X.M.; Ren, J.G.; Jiang, C.Y.; Wan, C.R. Electrochemical characteristics of sulfur composite cathode materials in rechargeable lithium batteries. J. Power Sources 2004, 138, 271-273. [CrossRef]

248. Wang, J.L.; Yang, J.; Xie, J.Y.; Xu, N.X. A novel conductive polymer-sulfur composite cathode material of rechargeable lithium batteries. Adv. Mater. 2002, 14, 963-996. [CrossRef]

249. Wang, J.L.; Yang, J.; Wan, C.R.; Du, K.; Xie, J.Y.; Xu, N.X. Sulfur composite cathode materials for rechargeable lithium batteries. Adv. Funct. Mater. 2003, 13, 487-492. [CrossRef]

250. Wang, J.L.; Liu, L.; Ling, Z.J.; Yang, J.; Wan, C.R.; Jiang, C.Y. Polymer lithium cells with sulfur composites as cathode materials. Electrochim. Acta 2003, 48, 1861-1867. [CrossRef]

251. Hassoun, J.; Sun, Y.-K.; Scrosati, B.J. Rechargeable lithium sulfide electrode for a polymer tin/sulfur lithium ion battery. Power Sources 2011, 196, 343-348. [CrossRef]

252. Zhang, B.; Qin, X.; Li, G.R.; Gao, X.P. Enhancement of long stability of sulfur cathode by encapsulating sulfur into micropores of carbon spheres. Energy Env. Sci. 2010, 3, 1531. [CrossRef]

253. Polyacrylonitrile Encyclopædia. In Encyclopædia Britannica; Britannica Inc.: London, UK, 2014.

254. National Center for Biotechnology Information. PubChem Database. Acrylonitrile, CID=7855. Available online: https://pubchem.ncbi.nlm.nih.gov/compound/Acrylonitrile (accessed on 20 May 2020).

255. National Center for Biotechnology Information. PubChem Database. Ethylene carbonate, $\mathrm{CID}=7303$. Available online: https://pubchem.ncbi.nlm.nih.gov/compound/Ethylene-carbonate (accessed on 12 May 2020).

256. National Center for Biotechnology Information. PubChem Database. Diethyl carbonate, CID=7766. Available online: https://pubchem.ncbi.nlm.nih.gov/compound/Diethyl-carbonate (accessed on 12 May 2020).

257. National Center for Biotechnology Information. PubChem Database. Propylene carbonate, $\mathrm{CID}=7924$. Available online: https://pubchem.ncbi.nlm.nih.gov/compound/Propylene-carbonate (accessed on 12 May 2020).

258. LTS Research Laboratories Inc. Lithium Hexafluorophosphate. Safety Data Sheet. 2015. Available online: https://www.ltschem.com/msds/LiPF6.pdf (accessed on 22 May 2020).

259. Lee, Y.M.; Choi, N.; Park, J.H.; Park, J. Electrochemical performance of lithium/sulfur batteries with protected Li anodes. J. Power Sources 2003, 119, 964-972. [CrossRef]

260. Rao, M.; Geng, X.; Li, X.; Hu, S.; Li, W. Lithium-sulfur cell with combining carbon nanofibers-sulfur cathode and gel polymer electrolyte. J. Power Sources 2012, 212, 179-185. [CrossRef]

261. Nagao, M.; Hayashi, A.; Tatsumisago, M. Sulfur-carbon composite electrode for all-solid-state Li/S battery with $\mathrm{Li}_{2} \mathrm{~S}_{-} \mathrm{P}_{2} \mathrm{~S}_{5}$ solid electrolyte. Electrochim. Acta 2011, 56, 6055-6059. [CrossRef]

262. Unemoto, A.; Yasaku, S.; Nogami, G.; Tazawa, M.; Taniguchi, M.; Matsuo, M.; Ikeshoji, T.; Orimo, S. Development of bulk-type all-solid-state lithium-sulfur battery using $\mathrm{LiBH}_{4}$ electrolyte. Appl. Phys. Lett. 2014, 105, 083901. [CrossRef]

263. Wang, S.; Ding, Y.; Zhou, G.; Yu, G.; Manthiram, A. Durability of the $\mathrm{Li}_{1+\mathrm{x}} \mathrm{Ti}_{2-\mathrm{x}} \mathrm{Al}_{\mathrm{X}}\left(\mathrm{PO}_{4}\right)_{3}$ Solid Electrolyte in Lithium-Sulfur Batteries. ACS Energy Lett. 2016, 1, 1080-1085. [CrossRef]

264. Han, F.; Yue, J.; Fan, X.; Gao, T.; Luo, C.; Ma, Z.; Suo, L.; Wang, C. High-Performance All-Solid-State Lithium-Sulfur Battery Enabled by a Mixed-Conductive Li $_{2} S$ Nanocomposite. Nano Lett. 2016, 16, 4521-4527. [CrossRef]

265. Nagao, M.; Imade, Y.; Narisawa, H.; Kobayashi, T.; Watanabe, R.; Yokoi, T.; Tatsumi, T.; Kanno, R. All-solid-state Li-sulfur batteries with mesoporous electrode and thio-LISICON solid electrolyte. J. Power Sources 2013, 222, 237-242. [CrossRef]

266. Song, J.Y.; Wang, Y.Y.; Wan, C.C. Review of gel-type polimer electrolytes for lithium-ion batteries. J. Power Sources 1999, 77, 183-197. [CrossRef]

267. Kim, K.M.; Park, N.G.; Ryu, K.S.; Chang, S.H. Characteristics of PVdF-HFP/TiO 2 composite membrane electrolytes prepared by phase inversion and conventional casting methods. Electrochim. Acta 2006, 51, 5636-5644. [CrossRef]

268. Zhao, Y.; Zhang, Y.; Gosselink, D.; Doan, T.N.; Sadhu, M.; Cheang, H.J.; Chen, P. Polymer electrolytes for lithium/sulfur batteries. Membranes 2012, 2, 553-564. [CrossRef] [PubMed] 
269. SABIC Innovative Plastics. Polyphenylene ether. Material Safety Data Sheet. 2008. Available online: www.sabic-ip.com (accessed on 20 May 2020).

270. Manoukian, O.S.; Sardashti, N.; Stedman, T.; Gailiunas, K.; Ojha, A.; Penalosa, A.; Mancuso, C.; Hobert, M.; Kumbar, S.G. Biomaterials for Tissue Engineering and Regenerative Medicine. In Encyclopedia of Biomedical Engineering; Narayan, R., Ed.; Elsevier: Amsterdam, The Netherlands, 2019; pp. 462-482.

271. ToxTown. Polyvinyl Chloride [PVC]. 2017. Available online: https://toxtown.nlm.nih.gov/chemicals-andcontaminants/polyvinyl-chloride-pvc (accessed on 20 May 2020).

272. Ensinger Inc. Tecaflon PVDF. Safety Data Sheet. 2015. Available online: http://www.ensinger-online.com/ modules/nonpublic/customersheet/openpdf.php?pdf=TECAFLON\%20PVDF\%20SDS\%20-\%202015-min. pdf (accessed on 22 May 2020).

273. Carbosynth Ltd. Poly(vinylidene fluoride-co-hexafluoropropylene). CAS No.: 9011-17-0. Safety Data Sheet. 2018. Available online: www.carbosynth.com (accessed on 20 May 2020).

274. Weston, J.E.; Steele, B.C.H. Effects of inert fillers on the mechanical and electrochemical properties of lithium salt poly(ethylene-oxide) polymer electrolytes. Solid State Ion. 1982, 7, 75-79. [CrossRef]

275. Jeon, B.H.; Yeon, J.H.; Chung, I.J. Preparation and electrical properties of lithium-sulfur-composite polymer batteries. J. Mater. Process. Technol. 2003, 143, 93-97. [CrossRef]

276. Appetecchi, G.B.; Croce, F.; Persi, L.; Ronci, F.; Scrosati, B. Transport and interfacial properties of composite polymer electrolytes. Electrochim. Acta 2000, 45, 1481-1490. [CrossRef]

277. Chung, S.H.; Wang, Y.; Persi, L.; Croce, F.; Greenbaum, S.G.; Scrosati, B.; Plichta, E. Enhancement of ion transport in polymer electrolytes by addition of nanoscale inorganic oxides. J. Power Sources 2001, 9, 644-648. [CrossRef]

278. Croce, F.; Persi, L.; Scrosati, B.; Serraino-Fiory, F.; Plichta, E.; Hendrickson, M.A. Role of the ceramic fillers in enhancing the transport properties of composite polymer electrolytes. Electrochim. Acta 2001, 46, 2457-2461. [CrossRef]

279. Ahn, J.H.; Wang, G.X.; Liu, H.K.; Dou, S.X. Nanoparticle-dispersed PEO polimer electrolytes for Li batteries. J. Power Sources 2003, 119, 422-426. [CrossRef]

280. Dissanayake, M.A.K.L.; Jayathilaka, P.A.R.D.; Bokalawala, R.S.P.; Albinsson, I.; Mellander, B.-E. Effect of concentration and grain size of alumina filler on the ionic conductivity enhancement of the (PEO) $9 \mathrm{LiCF}_{3} \mathrm{SO}_{3}: \mathrm{Al}_{2} \mathrm{O}_{3}$ composite polymer electrolyte. J. Power Sources 2003, 119, 409-414. [CrossRef]

281. Lin, C.W.; Hung, C.L.; Venkateswarlu, M.; Hwang, B.J. Influence of $\mathrm{TiO}_{2}$ nano-particles on the transport properties of composite polymerel ectrolyte for lithium-ion batteries. J. Power Sources 2005, 146, 397-401. [CrossRef]

282. Sergent, J.A.; Paget, V.; Chevillard, S. Toxicity and genotoxicity of nano-SiO ${ }_{2}$ on human epithelial intestinal HT-29 cell line. Ann. Occup. Hyg. 2012, 56, 622-630. [PubMed]

283. Carl Roth GmbH + Co KG. Silicon dioxide. Safety Data Sheet, Version 1.0. 2016. Available online: www.carlroth.de (accessed on 20 May 2020).

284. Arefian, Z.; Pishbin, F.; Negahdary, M.; Ajdary, M. Potential toxic effects of Zirconia Oxide nanoparticles on liver and kidney factors. Biomed. Res. 2015, 26, 89-97.

285. LTS Research Laboratories Inc. Zirconium oxide. Safety Data Sheet. 2015. Available online: https: //www.ltschem.com/msds/ZrO2.pdf (accessed on 22 May 2020).

286. National Center for Biotechnology Information. PubChem Database. Alumina, CID=14769. Available online: https://pubchem.ncbi.nlm.nih.gov/compound/Alumina (accessed on 21 May 2020).

287. LTS Research Laboratories Inc. Lithium Aluminate. Safety Data Sheet. 2016. Available online: https: //www.ltschem.com/msds/LiAlO2.pdf (accessed on 22 May 2020).

288. Croce, F.; Sacchetti, S.; Scrosati, B. Advanced, high-performance composite polymer electrolytes for lithium batteries. J. Power Sources 2006, 161, 560-564. [CrossRef]

289. Croce, F.; Settimi, L.; Scrosati, B. Super acid $\mathrm{ZrO}_{2}$-added, composite polymer electrolytes with improved transport properties. Electrochem. Commun. 2006, 8, 364-368. [CrossRef]

290. Liang, X.; Wen, Z.; Liu, Y.; Zhang, H.; Huang, L.; Jin, J. Highly dispersed sulphur in ordered mesoporous carbon sphere as a composite cathode for rechargeable polymer Li/S battery. J. Power Sources 2011, 196, 3655-3658. [CrossRef]

291. Xu, J.J.; Ye, H. Polymer gel electrolytes based on oligomeric polyether/cross-linked PMMA blends prepared via in situ polymerization. Electrochem. Commun. 2005, 7, 829-835. [CrossRef] 
292. Shin, J.H.; Jung, S.S.; Kim, K.W.; Ahn, H.J.; Ahn, J.H. Preparation and characterization of plasticized polimer electrolytes based on the PVdF-HFP copolymer for lithium/sulphur battery. J. Mater. Sci. Mater. Electron. 2002, 13, 727-733. [CrossRef]

293. Wang, J.L.; Yang, J.; Xie, J.Y.; Xu, N.X.; Li, Y. Sulfur-carbon nano-composite as cathode for rechargeable lithium battery based on gel electrolyte. Electrochem. Commun. 2002, 4, 499-502. [CrossRef]

294. Ryu, H.-S.; Ahn, H.-J.; Kim, K.-W.; Ahn, J.-H.; Lee, J.-Y. Discharge process of Li/PVdF/S cells at room temperature. J. Power Sources 2006, 153, 360-364. [CrossRef]

295. Zhang, S.S.; Tran, D.T. How a gel polymer electrolyte affects performance of lithium/sulphur batteries. Electrochim. Acta 2013, 114, 296-302. [CrossRef]

296. National Center for Biotechnology Information. PubChem Database. Tetraglyme, CID=8925. Available online: https://pubchem.ncbi.nlm.nih.gov/compound/Tetraglyme (accessed on 13 May 2020).

297. Lenntech. Chemical properties of tin-Health effects of tin-Environmental effects of tin. Available online: https://www.lenntech.com/periodic/elements/sn.htm (accessed on 13 May 2020).

298. Digital Fire Reference Library. Zirconium Compounds Toxicity. Available online: https:/digitalfire.com/ 4sight/hazards/ceramic_hazard_zirconium_compounds_toxicity_373.html (accessed on 13 May 2020).

299. Liu, M.; Zhou, D.; He, Y.; Fu, Y.; Qin, X.; Miao, C.; Du, H.; Li, B.; Yang, Q.; Lin, Z. Novel gel polymer electrolyte for high-performance lithium-sulfur batteries. Nano Energy 2016, 22, 278-289. [CrossRef]

300. Liu, M.; Jiang, H.; Ren, Y.; Zhou, D.; Kang, F.; Zhao, T. In-situ Fabrication of a Freestanding Acrylate-based Hierarchical Electrolyte for Lithium-sulfur Batteries. Electrochim. Acta 2016, 213, 871-878. [CrossRef]

301. NTP Report on the Toxicology Studies of Pentaerythritol Triacrylate (Technical Grade) (CAS NO. 3524-68-3). In F344/N Rats, B6C3F1 Mice, and Genetically Modified (FVB Tg.AC HEMIZYGOUS) Mice (Dermal Studies); NTP GMM 4. NIH Publication No. 06-4451; National Toxicology Program: Durham, NC, USA, 2005.

302. National Center for Biotechnology Information. PubChem Database. Pentaerythritol tetraacrylate, $\mathrm{CID}=62556$. Available online: https://pubchem.ncbi.nlm.nih.gov/compound/Pentaerythritol-tetraacrylate (accessed on 21 May 2020).

303. Adachi, G.Y.; Imanaka, N.; Aono, H. Fast Li-circle plus conducting ceramic electrolytes. Adv. Mater. 1996, 8 , 127-135. [CrossRef]

304. Robertson, A.D.; West, A.R.; Ritchie, A.G. Review of crystalline lithium-ion conductors suitable for high temperature battery applications. Solid State Ion. 1997, 104, 1-11. [CrossRef]

305. Thangadurai, V.; Weppner, W. Recent progress in solid oxide and lithium ion conducting electrolytes research. Ionics 2006, 12, 81-92. [CrossRef]

306. Thangadurai, V.; Narayanan, S.; Pinzaru, D. Garnet-type solid-state fast Li ion conductors for Li batteries: Critical review. Chem Soc. Rev. 2014, 43, 4714-4727. [CrossRef]

307. Stramare, S.; Thangadurai, V.; Weppner, W. Lithium lanthanum titanates: A review. Chem. Mater. 2003, 15, 3974-3990. [CrossRef]

308. Le, D.T. Influence of Lithium Content on the Structure and Ionic Conductivity of Perovskite $\mathrm{La}_{(2-3)-\mathrm{x}} \mathrm{Li}_{3 \mathrm{x}} \mathrm{TiO}_{3}$ made by Double Mechanical Alloying Method. Commun. Phys. 2014, 24, 33-39.

309. Noah Technologies Corporation SDS. Lithium Orthosilicate. Safety Data Sheet No. 272. 2019. Available online: https://noahtech.com/data/safety.13373.pdf (accessed on 22 May 2020).

310. Materion Advanced Chemicals Inc. Lithium orthosilicate [Li4SiO4]. Safety Data Sheet. 2020. Available online: https://www.materion.com/api/materion/Msds/Download?fileName=2MJ_LITHIUM\% 20ORTHOSILICATE\%20(LI4SIO4)_SDS-EU_EU\%20English.pdf (accessed on 22 May 2020).

311. Hayashi, A.; Hama, S.; Morimoto, H.; Tatsumisago, M.; Minami, T. Preparation of $\mathrm{Li}_{2} \mathrm{~S}_{-} \mathrm{P}_{2} \mathrm{~S}_{5}$ amorphous solid electrolytes by mechanical milling. J. Am. Ceram. Soc. 2001, 84, 477-479. [CrossRef]

312. Hayashi, A.; Ohtomo, T.; Mizuno, F.; Tadanaga, K.; Tatsumisago, M. Rechargeable lithium batteries, using sulfur-based cathode materials and $\mathrm{Li}_{2} \mathrm{~S}-\mathrm{P}_{2} \mathrm{~S}_{5}$ glass-ceramic electrolytes. Electrochim. Acta 2004, 50, 893-897. [CrossRef]

313. Nagao, M.; Hayashi, A.; Tatsumisago, M. Fabrication of favorable interface between sulfide solid electrolyte and Li metal electrode for bulk-type solid-state Li/S battery. Electrochem. Commun. 2012, 22, 177-180. [CrossRef]

314. Teragawa, S.; Aso, K.; Tadanaga, K.; Hayashi, A.; Tatsumisago, M. Preparation of $\mathrm{Li}_{2} \mathrm{~S}-\mathrm{P}_{2} \mathrm{~S}_{5}$ solid electrolyte from N-methylformamide solution and application for all-solid-state lithium battery. J. Power Sources 2014, 248, 939-942. [CrossRef] 
315. Agostini, M.; Aihara, Y.; Yamada, T.; Scrosati, B.; Hassoun, J. A lithium-sulfur battery using a solid, glass-type $\mathrm{P}_{2} \mathrm{~S}_{5}-\mathrm{Li}_{2} \mathrm{~S}$ electrolyte. Solid State Ion. 2013, 244, 48-51. [CrossRef]

316. Yamada, T.; Ito, S.; Omoda, R.; Watanabe, T.; Aihara, Y.; Agostini, M.; Ulissi, U.; Hassoun, J.; Scrosati, B. All Solid-State Lithium-Sulfur Battery Using a Glass-Type $\mathrm{P}_{2} \mathrm{~S}_{5}-\mathrm{Li}_{2} \mathrm{~S}$ Electrolyte: Benefits on Anode Kinetics. J. Electrochem. Soc. 2015, 162, A646-A651. [CrossRef]

317. Hayashi, A.; Hama, S.; Morimoto, H.; Tatsumisago, M.; Minami, T. High lithium ion conductivity of glass-ceramics derived from mechanically milled glassy powders. Chem. Lett. 2001, 84, 872-873. [CrossRef]

318. Hayashi, A.; Hama, S.; Minami, T.; Tatsumisago, M. Formation of superionic crystals from mechanically milled $\mathrm{Li}_{2} \mathrm{~S}-\mathrm{P}_{2} \mathrm{~S}_{5}$ glasses. Electrochem. Commun. 2003, 5, 111-114. [CrossRef]

319. MTI Corporation. Li7P3S11 LPS. Safety Data Sheet. 2018. Available online: http://www.mtixtl.com/sds/LPS_ SDS.pdf (accessed on 22 May 2020).

320. Kamaya, N.; Homma, K.; Yamakawa, Y.; Hirayama, M.; Kanno, R.; Yonemura, M.; Kamiyama, T.; Kato, Y.; Hama, S.; Kawamoto, K.; et al. A lithium superionic conductor. Nat. Mater. 2011, 10, 682-686. [CrossRef]

321. Nagata, H.; Chikusa, Y. A lithium sulfur battery with high power density. J. Power Sources 2014, 264, $206-210$. [CrossRef]

322. MTI Corporation EQ-Lib-LGPS LGPS (Li10GeP2S12) Powder with High Ion-Conductivity. Specification and Safety Data Sheet. 2018. Available online: http://www.mtixtl.com/sds/LGPS_SDS.pdf (accessed on 22 May 2020).

323. Liu, Z.C.; Fu, W.J.; Payzant, E.A.; Yu, X.; Wu, Z.L.; Dudney, N.J.; Kiggans, J.; Hong, K.; Rondinone, A.J.; Liang, C. Anomalous high ionic conductivity of nanoporous beta-Li3PS4. J. Am. Chem. Soc. 2013, 135, 975-978. [CrossRef]

324. Lin, Z.; Liu, Z.C.; Dudney, N.J.; Liang, C.D. Lithium superionic sulfide cathode for all-solid lithium-sulfur batteries. ACS Nano 2013, 7, 2829-2833. [CrossRef]

325. Lin, Z.; Liu, Z.C.; Fu, W.J.; Dudney, N.J.; Liang, C.D. Lithium polysulfidophosphates: A family of lithium-conducting sulfur-rich compounds for lithium-sulfur batteries. Angew. Chem. Int Ed. 2013, 52, 7460-7463. [CrossRef] [PubMed]

326. NEI Corporation. LPS-Lithium Phosphorus Sulfide ( $\beta$-Li3PS4) powder. Safety Data Sheet. 2020. Available online: https://neicorporation.com/msds/Li3PS4_Lithium_Phosphorus_Sulfide_SDS.pdf (accessed on 22 May 2020).

327. LTS Research Laboratories Inc. Lithium Phosphorus Sulfide. Safety Data Sheet. 2017. Available online: https://www.ltschem.com/msds/Li3PS4.pdf (accessed on 22 May 2020).

328. Liu, Z.; Huang, F.; Yang, J.; Wang, B.; Sun, J. New lithium ion conductor, thio-LISICON lithium zirconium sulfide system. Solid State Ion. 2008, 179, 1714-1716. [CrossRef]

329. Liu, Z.; Huang, F.; Yang, J.; Wang, Y.; Sun, J. Preparation of new lithium ion composite electrolyte $3 \mathrm{Li}_{4} \mathrm{SiS}_{4}-0.5 \mathrm{La}_{2} \mathrm{~S}_{3}$ by mechanical milling. Solid State Sci. 2008, 10, 1429-1433. [CrossRef]

330. LTS Research Laboratories Inc. Silicon Sulfide. Safety Data Sheet. 2015. Available online: https://www. ltschem.com/msds/SiS2.pdf (accessed on 22 May 2020).

331. Indium, RSC. Available online: https:/www.rsc.org/periodic-table/element/49/indium (accessed on 20 May 2020).

332. NEI Corporation. LPSCl—Lithium Phosphorus Sulfur Chloride (Li6PS5Cl) powder. Safety Data Sheet. 2020. Available online: https://neicorporation.com/msds/Li6PS5Cl_Lithium_Phosphorus_Sulfur_Chloride_SDS. pdf (accessed on 22 May 2020).

333. Aurbach, D.; Pollak, E.; Elazari, R.; Salitra, G.; Kelley, C.S.; Affinito, J. On the surface chemical aspects of very high energy density, rechargeable Li-sulfur batteries. J. Electrochem. Soc. 2009, 156, A694. [CrossRef]

334. National Center for Biotechnology Information. PubChem Database. Lithium nitrate, CID=10129889. Available online: https://pubchem.ncbi.nlm.nih.gov/compound/Lithium-nitrate (accessed on 8 May 2020).

335. Demir-Cakan, R.; Morcrette, M.; Gangulibabu, B.; Guéguen, A.; Dedryvère, R.; Tarascon, J.-M. Li-S batteries: Simple approaches for superior performance. Energy Env. Sci. 2013, 6, 176-182. [CrossRef]

336. Xiong, S.Z.; Xie, K.; Diao, Y.; Hong, X.B. On the role of polysulfides for a stable solid electrolyte interphase on the lithium anode cycled in lithium-sulfur batteries. J. Power Sources 2013, 236, 181-187. [CrossRef]

337. Xiong, S.; Xie, K.; Diao, Y.; Hong, X. Characterization of the solid electrolyte interphase on lithium anode for preventing the shuttle mechanism in lithium-sulfur batteries. J. Power Sources 2014, 246, 840-845. [CrossRef] 
338. National Center for Biotechnology Information. PubChem Database. Lithium sulfide (Li2S), $\mathrm{CID}=64734$. Available online: https://pubchem.ncbi.nlm.nih.gov/compound/Lithium-sulfide-_Li2S (accessed on 8 May 2020).

339. Lin, Z.; Liu, Z.; Fu, W.; Dudney, N.J.; Liang, C. Phosphorous pentasulfide as a novel additive for high-performance lithium-sulfur batteries. Adv. Funct. Mater. 2013, 23, 1064-1069. [CrossRef]

340. National Center for Biotechnology Information. PubChem Database. Phosphorus pentasulfide, CID=14817. Available online: https://pubchem.ncbi.nlm.nih.gov/compound/Phosphorus-pentasulfide (accessed on 8 May 2020).

341. Morris, C. MIT researchers discover two forms of lithium dendrite formation. Charged Electric Vehicles Magazine. 21 September 2016. Newswire The Tech. Available online: https://chargedevs.com/newswire/mitresearchers-discover-two-forms-of-dendrite-formation/ (accessed on 8 May 2020).

342. Liu, M.; Zhou, D.; Jiang, H.; Ren, Y.; Kang, F.; Zhao, T. A highly-safe lithium-ion sulfur polymer battery with $\mathrm{SnO} 2$ anode and acrylate-based gel polymer electrolyte. Nano Energy 2016, 28, 97-105. [CrossRef]

343. Pu, X.; Yang, G.; Yu, C. Safe and reliable operation of sulfur batteries with lithiated silicon. Nano Energy 2014, 9, 318-324. [CrossRef]

344. Zhang, X.; Wang, W.; Wang, A.; Huang, Y.; Yuan, K.; Yu, Z.; Qiu, J.; Yang, Y. Improved cycle stability and high security of Li-B alloy anode for lithium-sulfur battery. J. Mater. Chem. A 2014, 2, 11660-11665. [CrossRef]

345. Agostini, M.; Hassoun, J.; Liu, J.; Jeong, M.; Nara, H.; Momma, T.; Osaka, T.; Sun, Y.; Scrosati, B. A Lithium-Ion Sulfur Battery Based on a Carbon-Coated Lithium-Sulfide Cathode and an Electrodeposited Silicon-Based Anode. ACS Appl. Mater. Interfaces 2014, 6, 10924-10928. [CrossRef] [PubMed]

346. Moreno, N.; Agostini, M.; Caballero, A.; Morales, J.; Hassoun, J. A long-life lithium ion sulfur battery exploiting high performance electrodes. Chem. Commun. 2015, 51, 14540-14542. [CrossRef] [PubMed]

347. Alfa Aesar Thermo Fisher Scientific Chemicals Inc. Indium(III) iodide. CAS 13510-35-5. Safety Data Sheet. 2018. Available online: www.alfa.com (accessed on 20 May 2020).

348. Sigma-Aldrich. Poly(3,4-ethylenedioxythiophene)-blockpoly(ethylene glycol) solution. Material Safety Data Sheet, Version 6.0. 2020. Available online: www.sigma-aldrich.com (accessed on 22 May 2020).

349. National Center for Biotechnology Information. PubChem Database. Trilithium nitride, CID=520242. Available online: https://pubchem.ncbi.nlm.nih.gov/compound/Trilithium-nitride (accessed on 22 May 2020).

350. Zhang, X.-W.; Li, Y.; Khan, S.A.; Fedkiw, P.S. Inhibition of lithium dendrites by fumed silica-based composite electrolytes. J. Electrochem. Soc. 2004, 151, A1257-A1263. [CrossRef]

351. Tatsuma, T.; Taguchi, M.; Oyama, N. Inhibition effect of covalently cross-linked gel electrolytes on lithium dendrite formation. Electrochim. Acta 2001, 46, 1201-1205. [CrossRef]

352. Steiger, J.; Richter, G.; Wenk, M.; Kramer, D.; Mönig, R. Comparison of the growth of lithium filaments and dendrites under different conditions. Electrochem. Commun. 2015, 50, 11-14. [CrossRef]

353. Bouchet, R. Batteries: A stable lithium metal interface. Nat. Nanotechnol. 2014, 9, 572-573. [CrossRef]

354. Li, W.; Yao, H.; Yan, K.; Zheng, G.; Liang, Z.; Chiang, Y.; Cui, Y. The synergetic effect of lithium polysulfide and lithium nitrate to prevent lithium dendrite growth. Nat. Commun. 2015, 6, 7436. [CrossRef]

355. Yan, C.; Cheng, X.; Zhao, C.; Huang, J.; Yang, S.; Zhang, Q. Lithium metal protection through in-situ formed solid electrolyte interphase in lithium-sulfur batteries: The role of polysulfides on lithium anode. J. Power Sources 2016, 327, 212-220. [CrossRef]

356. Cheng, X.-B.; Huang, J.-Q.; Zhang, Q. Review-Li Metal Anode in Working Lithium-Sulfur Batteries. J. Electrochem. Soc. 2018, 165, A6058-A6072. [CrossRef]

357. Raymor Nanotech, division of Raymor Industries Inc. Carbon nanotube, single-walled. Safety Data Sheet. 2014. Available online: http://raymor.com/wp-content/uploads/2014/10/MSDS-SWNT-RN-020.pdf (accessed on 22 May 2020).

358. Acros Organics BVBA. Graphite, Powder. CAS 7782-42-5. Material Safety Data Sheet. 2009. Available online: https://www.nwmissouri.edu/naturalsciences/sds/g/Graphite.pdf (accessed on 22 May 2020).

359. LTS Research Laboratories Inc. Titanium carbide. Safety Data Sheet. 2015. Available online: https: //www.ltschem.com/msds/TiC.pdf (accessed on 22 May 2020).

360. AquaPhoenix Scientific. Copper, Granular, 50 Mesh. Safety Data Sheet. 2015. Available online: https://beta-static.fishersci.com/content/dam/fishersci/en_US/documents/programs/education/ regulatory-documents/sds/chemicals/chemicals-c/S25268.pdf (accessed on 22 May 2020). 
361. LTS Research Laboratories Inc. Copper nickel. Safety Data Sheet. 2015. Available online: https://www. ltschem.com/msds/CuNi.pdf (accessed on 22 May 2020).

362. Ladd Research. Nickel. Safety Data Sheet. 2020. Available online: https://www.laddresearch.com/ lanotattachments/download/file/id/542/store/1/60810sds_1.pdf (accessed on 22 May 2020).

363. LTS Research Laboratories Inc. Aluminum fluoride Safety Data Sheet. 2015. Available online: https: //www.ltschem.com/msds/AlF3.pdf (accessed on 22 May 2020).

364. Cheng, X.-B.; Peng, H.-J.; Huang, J.-Q.; Wei, F.; Zhang, Q. Dendrite-free Nanostructured Anode: Entrapment of Lithium in a 3D Fibrous Matrix for Ultra-Stable Lithium-Sulfur Batteries. Small 2014, 10, 4257. [CrossRef] [PubMed]

365. Liu, Y.; Lin, D.; Liang, Z.; Zhao, J.; Yan, K.; Cui, Y. Lithium-coated polymeric matrix as a minimum volume-change and dendrite-free lithium metal anode. Nat. Commun. 2016, 7, 10992. [CrossRef] [PubMed]

366. Liang, Z.; Lin, D.; Zhao, J.; Lu, Z.; Liu, Y.; Liu, C.; Lu, Y.; Wang, H.; Yan, K.; Tao, X.; et al. Composite Lithium Metal Anode by Melt Infusion of Lithium Into a 3D Conducting Scaffold With Lithiophilic Coating. Proc. Natl. Acad. Sci. USA 2016, 113, 2862-2867. [CrossRef] [PubMed]

367. Lin, D.; Liu, Y.; Liang, Z.; Lee, H.-W.; Sun, J.; Wang, H.; Yan, K.; Xie, J.; Cui, Y. Layered Reduced Graphene Oxide With Nanoscale Interlayer Gaps as a Stable Host for Lithium Metal Anodes. Nat. Nanotechnol. 2016, 11, 626-632. [CrossRef] [PubMed]

368. Jin, C.; Sheng, O.; Luo, J.; Yuan, H.; Fang, C.; Zhang, W.; Huang, H.; Gan, Y.; Xia, Y.; Liang, C.; et al. 3D lithium metal embedded within lithiophilic porous matrix for stable lithium metal batteries. Nano Energy 2017, 37, 177-186. [CrossRef]

369. Lin, D.; Liu, Y.; Chen, W.; Zhou, G.; Liu, K.; Dunn, B.; Cui, Y. Conformal Lithium Fluoride Protection Layer on Three-Dimensional Lithium by Nonhazardous Gaseous Reagent Freon. Nano Lett. 2017, 17, 3731-3737. [CrossRef] [PubMed]

370. Takehara, Z.; Ogumi, Z.; Uchimoto, Y.; Yasuda, K.; Yoshida, H. Modification of lithium/electrolyte interface by plasma polymerization of 1,1-difluoroethene. J. Power Sources 1993, 44, 377-383. [CrossRef]

371. Osaka, T.; Momma, T.; Matsumoto, Y.; Uchida, Y. Effect of carbon dioxide on lithium anode cycleability with various substrates. J. Power Sources 1997, 68, 497-500. [CrossRef]

372. Osaka, T.; Momma, T.; Matsumoto, Y.; Uchida, Y. Surface Characterization of Electrodeposited Lithium Anode with Enhanced Cycleability Obtained by $\mathrm{CO}_{2}$ Addition. J. Electrochem. Soc. 1997, 144, 1709-1713. [CrossRef]

373. National Center for Biotechnology Information. PubChem Database. Lithium carbonate, $\mathrm{CID}=11125$. Available online: https://pubchem.ncbi.nlm.nih.gov/compound/Lithium-carbonate (accessed on 14 May 2020).

374. Nimon, Y.; Chu, M.-Y.; Visco, S.J. Coated lithium electrodes. U.S. Patent 6,537,701, 25 March 2003.

375. Mikhaylik, Y.V. Electrolytes for lithium-sulfur cells. U.S. Patent 7,354,680, 8 April 2008.

376. Sigma-Aldrich. Aluminum oxide. Safety Data Sheet. Version 5.5. 2015. Available online: www.sigmaaldrich.com (accessed on 22 May 2020).

377. Alumina Toxicology. Available online: https:/digitalfire.com/4sight/hazards/ceramic_hazard_alumina_ toxicology_341.html (accessed on 22 May 2020).

378. Sadiq, I.M.; Pakrashi, S.; Chandrasekaran, N.; Mukherjee, A. Studies on toxicity of aluminum oxide $\left(\mathrm{Al}_{2} \mathrm{O}_{3}\right)$ nanoparticles to microalgae species: Scenedesmus sp. and Chlorella sp. J. Nanoparticle Res. 2011, 13, 3287-3299. [CrossRef]

379. Cha, E.; Patel, M.D.; Park, J.; Hwang, J.; Prasad, V.; Cho, K.; Choi, W. 2D MoS 2 as an efficient protective layer for lithium metal anodes in high-performance Li-S batteries. Nat. Nanotechnol. 2018, 13, 337-344.

380. Chen, W.; Qi, W.; Lu, W.; Chaudhury, N.R.; Yuan, J.; Qin, L.; Lou, J. Direct Assessment of the Toxicity of Molybdenum Disulfide Atomically Thin Film and Microparticles via Cytotoxicity and Patch Testing. Small 2018, 14, 1702600. [CrossRef] [PubMed]

381. Yao, H.; Yan, K.; Li, W.; Zheng, G.; Kong, D.; She, Z.W.; Narasimhan, V.K.; Liang, Z.; Cui, Y. Improved lithium-sulfur batteries with a conductive coating on the separator to prevent the accumulation of inactive S-related species at the cathode-separator interface. Energy Environ. Sci. 2014, 7, 3381-3390. [CrossRef]

382. Chung, S.-H.; Manthiram, A. High-performance Li-S batteries with an ultra-lightweight MWCNT-coated separator. J. Phys. Chem. Lett. 2014, 5, 1978-1983. [CrossRef] 
383. Fang, J.; Qin, F.; Li, J.; Zhang, K.; Liu, W.; Wang, M.; Yu, F.; Zhang, L. Improved performance of sulfur cathode by an easy and scale-up coating strategy. J. Power Sources 2015, 297, 265-270. [CrossRef]

384. Chung, S.; Manthiram, A. Bifunctional Separator with a Light-Weight Carbon-Coating for Dynamically and Statically Stable Lithium-Sulfur Batteries. Adv. Funct. Mater. 2014, 24, 5299-5306. [CrossRef]

385. Huang, J.-Q.; Zhang, Q.; Peng, H.-J.; Liu, X.-Y.; Qian, W.-Z.; Wei, F. Ionic shield for polysulfides towards highly-stable lithium-sulfur batteries. Energy Environ. Sci. 2014, 7, 347-353. [CrossRef]

386. Hwang, J.; Choi, D.; Han, S.; Choi, J.; Hong, J. An assessment of the toxicity of polypropylene microplastics in human derived cells. Sci. Total Environ. 2019, 684, 657-669. [CrossRef]

387. Allegri, M.; Perivoliotis, D.K.; Bianchi, M.G.; Chiu, M.; Pagliaro, A.; Koklioti, M.A.; Trompeta, A.-F.A.; Bergamaschi, E.; Bussolati, O.; Charitidis, C.A. Toxicity determinants of multi-walled carbon nanotubes: The relationship between functionalization and agglomeration. Toxicol. Rep. 2016, 3, 230-243. [CrossRef]

388. Chaudhuri, I.; Fruijtier-Pölloth, C.; Ngiewih, Y.; Levy, L. Evaluating the evidence on genotoxicity and reproductive toxicity of carbon black: A critical review. Crit. Rev. Toxicol. 2018, 48, 143-169. [CrossRef]

389. TIMCAL Belgium N.V. Ensaco 150/210/250/260/350 granular, Ensaco 150/250P, Super P, Super P-Li, C-NERGY Super C 45/65. Material Safety Data Sheet. 2011. Available online: https://ehslegacy.unr.edu/msdsfiles/24831. pdf (accessed on 22 May 2020).

390. LUCENE LC180 Polyolefin Elastomer. Safety Data Sheet. LG Chem Ltd Deasan Plant, 2012. Available online: http://www.matweb.com/search/datasheettext.aspx?matguid=5cfea5ad7b944588a3818fc90bbdc12a (accessed on 22 May 2020).

391. U.S. Department of Health and Human Services; Public Health Service Agency for Toxic Substances and Disease Registry. Toxicological Profile for Aluminium. September 2008. Available online: https: //www.atsdr.cdc.gov/ToxProfiles/tp.asp?id=191\&tid=34 (accessed on 22 May 2020).

392. Wang, Y.; Kaur, G.; Zysk, A.; Liapis, V.; Hay, S.; Santos, A.; Losic, D.; Evdokiou, A. Systematic In Vitro Nanotoxicity Study on Anodic Alumina Nanotubes with Engineered Aspect Ratio: Understanding Nanotoxicity by A Nanomaterial Model. Biomaterials 2015, 46, 117. [CrossRef] [PubMed]

393. Chen, Y.; Yang, Y.; Xu, B.; Wang, S.; Li, B.; Ma, J.; Gao, J.; Zuo, Y.Y.; Liu, S. Mesoporous carbon nanomaterials induced pulmonary surfactant inhibition, cytotoxicity, inflammation and lung fibrosis. J. Env. Sci. 2017, 62, 100-114. [CrossRef] [PubMed]

394. Zhao, H.; Zeng, Z.; Liu, L.; Chen, J.; Zhou, H.; Huang, L.; Huang, J.; Xu, H.; Xu, Y.; Chen, Z.; et al. Polydopamine nanoparticles for the treatment of acute inflammation-induced injury. Nanoscale 2018, 10, 6981. [CrossRef] [PubMed]

395. Hesterberg, T.W.; Miller, W.C.; McConnell, E.E.; Chevalier, J.; Hadley, J.G.; Bernstein, D.M.; Thevenaz, P.; Anderson, R. Chronic inhalation toxicity of size-separated glass fibers in Fischer 344 rats. Fundam. Appl. Toxicol. 1993, 20, 464-476. [CrossRef] [PubMed]

396. Sun, Y.; Fan, S.; Fan, S.; Li, C.; Shang, Z.; Gu, M.; Liang, S.; Tian, X. In Vitro and In Vivo Toxicity of Black Phosphorus Nanosheets. J. Nanosci. Nanotechnol. 2020, 20, 659-667. [CrossRef]

397. Kalgutkar Amit, S.; Scott Daniels, J. Chapter 3: Carboxylic Acids and their Bioisosteres. In Metabolism, Pharmacokinetics and Toxicity of Functional Groups: Impact of Chemical Building Blocks on ADMET; Smith, D.A., Ed.; The Royal Society of Chemistry: Cambridge, UK, 2010; pp. 99-167.

398. Yu, X.; Joseph, J.; Manthiram, A. Suppression of the polysulfide-shuttle behavior in Li-S batteries through the development of a facile functional group on the polypropylene separator. Mater. Horiz 2016, 3, 314-319. [CrossRef]

399. Zhao, Y.; Liu, M.; Lv, W.; He, Y.; Wang, C.; Yun, Q.; Li, B.; Kang, F.; Yang, Q. Dense coating of $\mathrm{Li}_{4} \mathrm{Ti}_{5} \mathrm{O}_{12}$ and graphene mixture on the separator to produce long cycle life of lithium-sulfur battery. Nano Energy 2016, 30, 1-8. [CrossRef]

400. Kim, D.; Kim, J. Synthesis of Ti-based Oxide Nanoparticles and Their Electrochemical Properties. ECS Meet. Abstr. 2006, MA2006-01, 51.

401. Jo, M.R.; Nam, K.M.; Lee, Y.; Song, K.; Park, J.T.; Kang, Y.M. Phosphidation of $\mathrm{Li}_{4} \mathrm{Ti}_{5} \mathrm{O}_{12}$ nanoparticles and their electrochemical and biocompatible superiority for lithium rechargeable batteries. Chem. Commun. 2011, 47, 11474-11476. [CrossRef]

402. Ou, L.; Song, B.; Liang, H.; Liu, J.; Feng, X.; Deng, B.; Sun, T.; Shao, L. Toxicity of graphene-family nanoparticles: A general review of the origins and mechanisms. Part. Fibre Toxicol. 2016, 13, 57. [CrossRef] 
403. Sironval, V.; Reylandt, L.; Chaurand, P.; Ibouraadaten, S.; Palmai-Pallag, M.; Yakoub, Y.; Ucakar, B.; Rose, J.; Poleunis, C.; Vanbever, R.; et al. Respiratory hazard of Li-ion battery components: Elective toxicity of lithium cobalt oxide $\left(\mathrm{LiCoO}_{2}\right)$ particles in a mouse bioassay. Arch. Toxicol. 2018, 92, 1673-1684. [CrossRef] [PubMed]

404. Zhuang, T.; Huang, J.; Peng, H.; He, L.; Cheng, X.; Che, C.; Zhang, Q. Rational Integration of Polypropylene/Graphene Oxide/Nafion as Ternary-Layered Separator to Retard the Shuttle of Polysulfides for Lithium-Sulfur Batteries. Small 2016, 12, 381-389. [CrossRef] [PubMed]

405. Zhu, J.; Chen, C.; Lu, Y.; Zang, J.; Jiang, M.; Kim, D.; Zhang, X. Highly porous polyacrylonitrile/graphene oxide membrane separator exhibiting excellent anti-self-discharge feature for high-performance lithium-sulfur batteries. Carbon 2016, 101, 272-280. [CrossRef]

406. Sharma, S.K.; Sokhi, S.; Balomajumder, C.; Satapathi, S. Reusable graphene oxide nanofibers for enhanced photocatalytic activity: A detailed mechanistic study. J. Mater. Sci. 2017, 52, 5390-5403. [CrossRef]

407. Lee, J.; Yoon, J.; Kim, J.-H.; Lee, T.; Byun, H.-S. Electrospun PAN-GO composite nanofibers as water purification membranes: Research Article. J. Appl. Polym. Sci. 2017, 135, 45858. [CrossRef]

408. Bai, S.; Liu, X.; Zhu, K.; Wu, S.; Zhou, H. Metal-organic framework-based separator for lithium-sulfur batteries. Nat. Energy 2016, 1, 16094. [CrossRef]

409. Filippousi, M.; Turner, S.; Leus, K.; Siafaka, P.I.; Tseligka, E.D.; Vandichel, M.; Nanaki, S.G.; Vizirianakis, I.S.; Bikiaris, D.N.; Van Der Voort, P.; et al. Biocompatible Zr-based nanoscale MOFs coated with modified poly (epsilon-caprolactone) as anticancer drug carriers. Int. J. Pharm. 2016, 509, 208-218. [CrossRef]

410. Tamames-Tabar, C.; Cunha, D.; Imbuluzqueta, E.; Ragon, F.; Serre, C.; Blanco-Prieto, M.; Horcajada, P. Cytotoxicity of nanoscaled metal-organic frameworks. J. Mater. Chem. 2014, 2, 262-271. [CrossRef]

411. Ruyra, A.; Yazdi, A.; Espin, J.; Carné-Sánchez, A.; Roher, N.; Lorenzo, J.; Imaz, I.; Maspoch, D. Synthesis, culture medium stability, and in vitro and in vivo zebrafish embryo toxicity of metal-organic framework nanoparticles. Chem. Eur. J. 2015, 21, 2508-2518. [CrossRef]

412. Ren, F.; Yang, B.C.; Cai, J.; Jiang, Y.D.; Xu, J.; Wang, S. Toxic effect of zinc nanoscale metal-organic frameworks on rat pheochromocytoma (PC12) cells in vitro. J. Hazard. Mater. 2014, 271, 283-291. [CrossRef]

413. Grall, R.; Hidalgo, T.; Delic, J.; Garcia-Marquez, A.; Chevillard, S.; Horcajada, P. In vitro biocompatibility of mesoporous metal (III.; Fe, Al, Cr) trimesate MOF nanocarriers. J. Mater. Chem. B 2015, 3, 8279-8292. [CrossRef] [PubMed]

414. Wagner, A.; Liu, Q.; Rose, O.L.; Eden, A.; Vijay, A.; Rojanasakul, Y.; Dinu, C.Z. Toxicity screening of two prevalent metal organic frameworks for therapeutic use in human lung epithelial cells. Int. J. Nanomed. 2019, 14, 7583-7591. [CrossRef] [PubMed]

415. Chang, C.-H.; Chung, S.-H.; Manthiram, A. Effective Stabilization of a High-Loading Sulfur Cathode and a Lithium-Metal Anode in Li-S Batteries Utilizing SWCNT-Modulated Separators. Small 2016, 12, 174-179. [CrossRef] [PubMed]

416. Kobayashi, N.; Izumi, H.; Morimoto, Y. Review of toxicity studies of carbon nanotubes. J. Occup. Health 2017, 59, 394-407. [CrossRef]

417. Kumar, P.; Dwivedi, P.K.; Yadav, P.; Shelke, M.V. Chapter 3.8.2.-Separators for Li-ion Batteries. In Emerging Nanostructured Materials for Energy and Environmental Science, Environmental Chemistry for a Sustainable World; Saravanan, R., Mu, N., Kumar, R., Rabah, B., Eds.; Springer: New York, NY, USA, 2019; Volume 23, p. 151.

418. Weng, G.-M.; Yang, B.; Liu, C.-Y.; Du, G.-Y.; Li, E.Y.; Lu, Y.-C. Asymmetric allyl-activation of organosulfides for high-energy reversible redox flow batteries. Energy Environ. Sci. 2019, 12, 2244-2252. [CrossRef]

419. Mathew, D.E.; Sivalingam, G.; Murugavel, K.; Rani, G.J.; Sabu, T.; Stephan, A.M. A porous organic polymer-coated permselective separator mitigating self-discharge of lithium-sulfur batteries. Mater. Adv. 2020, 1, 648-657. [CrossRef]

420. Celgard, MTI-Korea. Li-ion Battery Separator Film, Material Safety Data Sheet. 2010. Available online: http://mtikorea.co.kr/web/smh/pdf/MSDS_separator_film.pdf (accessed on 22 May 2020).

(C) 2020 by the author. Licensee MDPI, Basel, Switzerland. This article is an open access article distributed under the terms and conditions of the Creative Commons Attribution (CC BY) license (http://creativecommons.org/licenses/by/4.0/). 